\title{
Exosome-Derived MicroRNAs of Human Milk and Their Effects on Infant Health and Development
}

\author{
Bodo C. Melnik $^{1, *(\mathbb{D}}$, Wolfgang Stremmel ${ }^{2}$, Ralf Weiskirchen ${ }^{3} \mathbb{D}$, Swen Malte John ${ }^{1,4}$ and Gerd Schmitz ${ }^{5}$ \\ 1 Department of Dermatology, Environmental Medicine and Health Theory, University of Osnabrück, \\ D-49076 Osnabrück, Germany; sjohn@uos.de \\ 2 Private Praxis for Internal Medicine, Beethovenstraße 2, D-76530 Baden-Baden, Germany; \\ wolfgangstremmel@aol.com \\ 3 Institute of Molecular Pathobiochemistry, Experimental Gene Therapy and Clinical Chemistry (IFMPEGKC), \\ RWTH University Hospital Aachen, D-52074 Aachen, Germany; rweiskirchen@ukaachen.de \\ 4 Institute for Interdisciplinary Dermatological Prevention and Rehabilitation (iDerm), \\ University of Osnabrück, D-49076 Osnabrück, Germany \\ 5 Institute for Clinical Chemistry and Laboratory Medicine, University Hospital of Regensburg, \\ University of Regensburg, D-93053 Regensburg, Germany; gerd.schmitz@ukr.de \\ * Correspondence: melnik@t-online.de; Tel.: +49-5241-988060
}

check for updates

Citation: Melnik, B.C.; Stremmel, W.; Weiskirchen, R.; John, S.M.; Schmitz, G. Exosome-Derived MicroRNAs of Human Milk and Their Effects on Infant Health and Development. Biomolecules 2021, 11, 851. https:// doi.org/10.3390/biom11060851

Academic Editor: Tamás Röszer

Received: 15 May 2021

Accepted: 1 June 2021

Published: 7 June 2021

Publisher's Note: MDPI stays neutral with regard to jurisdictional claims in published maps and institutional affiliations.

Copyright: (c) 2021 by the authors. Licensee MDPI, Basel, Switzerland. This article is an open access article distributed under the terms and conditions of the Creative Commons Attribution (CC BY) license (https:// creativecommons.org/licenses/by/ $4.0 /)$.

\begin{abstract}
Multiple biologically active components of human milk support infant growth, health and development. Milk provides a wide spectrum of mammary epithelial cell-derived extracellular vesicles (MEVs) for the infant. Although the whole spectrum of MEVs appears to be of functional importance for the growing infant, the majority of recent studies report on the MEV subfraction of milk exosomes (MEX) and their miRNA cargo, which are in the focus of this review. MEX and the dominant miRNA-148a play a key role in intestinal maturation, barrier function and suppression of nuclear factor- $\kappa \mathrm{B}(\mathrm{NF}-\mathrm{kB})$ signaling and may thus be helpful for the prevention and treatment of necrotizing enterocolitis. MEX and their miRNAs reach the systemic circulation and may impact epigenetic programming of various organs including the liver, thymus, brain, pancreatic islets, beige, brown and white adipose tissue as well as bones. Translational evidence indicates that MEX and their miRNAs control the expression of global cellular regulators such as DNA methyltransferase 1—which is important for the up-regulation of developmental genes including insulin, insulin-like growth factor-1, $\alpha$-synuclein and forkhead box P3-and receptor-interacting protein 140, which is important for the regulation of multiple nuclear receptors. MEX-derived miRNA-148a and miRNA-30b may stimulate the expression of uncoupling protein 1 , the key inducer of thermogenesis converting white into beige/brown adipose tissue. MEX have to be considered as signalosomes derived from the maternal lactation genome emitted to promote growth, maturation, immunological and metabolic programming of the offspring. Deeper insights into milk's molecular biology allow the conclusion that infants are both "breast-fed" and "breast-programmed". In this regard, MEX miRNA-deficient artificial formula is not an adequate substitute for breastfeeding, the birthright of all mammals.
\end{abstract}

Keywords: adipogenesis; DNA methyltransferase 1; immune tolerance; intestinal maturation; milk exosome; milk miRNAs; necrotizing enterocolitis; nuclear factor- $\mathrm{kB}$; receptor-interacting protein 140; systemic milk effects

\section{Introduction}

Breastfeeding is considered to represent the ideal source of infant nutrition. During the postnatal period, the infant's epithelial barrier of the gastrointestinal (GI) tract matures, while adaptive immunity is still developing [1]. Accumulating evidence indicates that human milk (HM) is critically involved in the regulation of intestinal maturation and immune cell education [2,3]. Multiple biologically active components of HM and various interacting signaling pathways drive developmental processes which remain largely obscure [4]. 
Recently, attention has been paid to the wide spectrum of lipid bilayer-enclosed milk extracellular vesicles (MEVs), especially the subfraction of milk exosomes (MEX) that contain proteins, lipids, mRNAs, microRNAs (miRNAs), circular RNAs (circRNAs) and long non-coding RNAs (lncRNAs). Our perception that milk is not "just food" for the growing infant but represents a complex metabolic and endocrine signaling system for postnatal growth and programming via transfer of mTORC1-activating amino acids and gene-regulatory miRNAs [5-7] has been substantiated in recent years. HM compared to other body fluids represents the richest source of miRNAs [8]. A large spectrum of bovine MEVs isolated by differential ultracentrifugation and their miRNA composition has recently been characterized $[9,10]$. MEX, a most important subfamily of MEVs, are biomolecular nanostructures released from mammary gland epithelial cells (MGECs), carrying specific biomolecular information. These nanosized particles 30-150 $\mathrm{nm}$ in diameter precipitate in the $100,000 \times g$ fraction of milk $[9,10]$. MEX are derived from the endolysosomal pathway and are released by intraluminal budding of multivesicular bodies with the cell membrane of MGECs. They are characterized by the proteins CD9, CD63, CD81, CD82, HSP70, HSP90, Alix, TSG101, annexin and Rab GTPases, among others. MEX are found in the milk of all mammals including $\mathrm{HM}$ and have received increasing scientific attention in recent years [11,12]. HM transfers functionally important miRNAs that primarily originate from human MGECs, resulting in unique miRNA profiles of fractionated HM [13]. MEX survive the harsh and degrading conditions in the gut, are taken up by various cell types, cross biological barriers and reach the blood circulation and peripheral tissues [14-19]. The most abundant miRNAs of milk fat-depleted HM is miRNA-148a followed by miRNA30a, miRNA-146b, miRNA-200a, miRNA-21, miRNA-200c, miRNA-26a, let-7f, let-7i and miRNA-146a [20,21]. miRNA-148a is also the most abundant miRNA of human MEX, accounting for almost $24 \%$ of total MEX miRNA and about $12 \%$ of miRNAs in whole HM [22] (Figure 1).

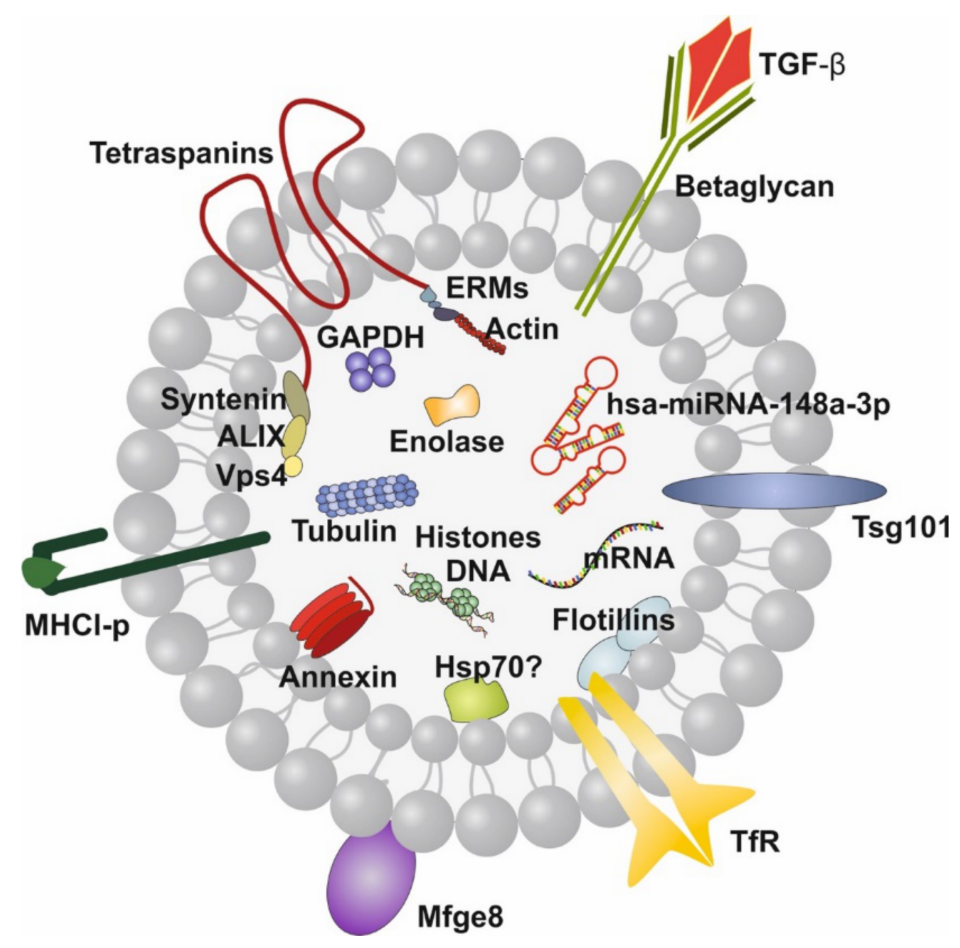

Figure 1. Illustration of a human milk exosome (MEX). The bilayer membrane is important for MEX resistance against the harsh conditions in the gastrointestinal tract. hsa-miRNA-148a-3p is the dominant miRNA of MEX. Note, MEX also contain transforming growth factor- $\beta$ (TGF- $\beta$ ). Tetraspanins are CD9, CD63, CD81 and CD83. 
miRNA-148a is also the most abundant miRNA of triacylglycerol-rich milk fat globules (MFGs) of HM [23]. Of note, miRNA-148a promotes triacylglycerol synthesis in MGECs [24]. Remarkably, the abundantly expressed miRNAs of human MEX exhibit striking nucleotide sequence homologies with the corresponding milk miRNAs of other mammals $[20,25]$. It has recently been demonstrated that the top 10 highly expressed MEX-derived miRNAs are evolutionarily conserved across the milk of various mammalian species, including humans [26]. miRNA-148a, which presents the most abundant miRNA packaged into MEX $[27,28]$, targets the mRNA of DNA methyltransferase 1 (DNMT1) $[20,27,28]$, and thus plays a critical role in MEX-mediated epigenetic regulation [29-31]. miRNA-148a also belongs to the most abundant MEX-derived immune-related miRNAs of HM [32]. Notably, the immune-related miRNAs enriched in MEX are resistant to harsh environmental conditions [32]. Accumulating evidence indicates that MEX are of critical importance for intestinal, immunological, metabolic and neurological programming and cell differentiation during the postnatal period of breastfeeding [20,27,28,33-41]. Importantly, MEX and their miRNAs are not detectable in artificial infant formula [42].

It is the intention of this review to provide up-to-date information on the impact of MEX and MEX-derived miRNAs on intestinal maturation and their systemic effects in human and animal tissues, which are important to understand the eminent role of MEX in infant health and development.

\section{Exosomal miRNAs and Intestinal Maturation}

\subsection{Intestinal Epithelial Cells}

Cells take up exosomes by a variety of endocytic pathways, including clathrindependent endocytosis, and clathrin-independent pathways such as caveolin-mediated uptake, macropinocytosis, phagocytosis and lipid raft-mediated internalization [43-45]. Bovine MEX uptake in human and rat intestinal epithelial cells (IECs) is mediated by endocytosis and depends on cell and exosome surface glycoproteins [46]. Upon gastric/pancreatic digestion, human MEX and their overall miRNA abundance was stable and entered human intestinal crypt-like cells (HIEC) with evidence of nuclear localization [14]. As predicted earlier [29,30], Golan-Gerstl et al. [20] demonstrated that incubation of human MEX with normal colon cells (CRL1831) significantly increased cellular levels of miRNA148a and decreased the expression of DNMT1. Furthermore, the addition of human MEX to normal fetal colon epithelial cells increased cell proliferation in an miRNA-dependent manner [27].

Insulin-like growth factor 1 (IGF-1)-mediated activation of phosphatidylinositol 3kinase (PI3K) is negatively regulated by phosphatase and tensin homolog (PTEN). PTEN is a direct target of miRNA-148a that is down-regulated following incubation with MEX [27]. Of note, knockdown of miRNA-148a inhibits IEC proliferation associated with an increase in the expression of DNMT1 [27]. It has been demonstrated in cultured human colonic LS174T cells that exposure to bovine MEX enhances the expression of glucose-regulated protein 94 (GRP94) [47], the most abundant intraluminal endoplasmic reticulum (ER) chaperone protein. GRP94 acts as an obligatory chaperone aiding the synthesis of IGF-1, IGF-2 [48] and proinsulin [49]. Furthermore, GRP94 plays a crucial role in gut homeostasis via chaperoning crucial components of the canonical WNT pathway [50]. GRP94 interacts with Mesoderm Development (MesD), a critical chaperone for the WNT co-receptor lowdensity lipoprotein receptor-related protein 6 (LRP6). Without GPR94, LRP6 fails to export from the ER to the cell surface, resulting in a profound loss of canonical WNT signaling [50]. Notably, mouse models harboring intestinal knockout of GRP94 led to WNT signaling defects through loss of the WNT co-receptor LRP6, resulting in early postnatal death with loss of intestinal barrier function, decreased number of villi and significant reduction in crypts [50]. 
IGF-1 plays an important role in intestinal growth [51] and is a bioactive hormone of HM [52]. The IGFs and their receptors in the stomach and duodenum are expressed in all age groups and are highest in the fetus [53]. The IGF system proteins are located in the gastric glands and epithelium and in the apical portion of the villous epithelium of the duodenum. Highest IGF-1 receptor (IGF1R) expression was found in the fetal GI tract [53]. Treatment with porcine MEX promoted IPEC-J2 cell proliferation, raised mice' villus height, crypt depth and the ratio of villus length to crypt depth of intestinal tissues. MEX also increased CDX2, PCNA and IGF1R and inhibited p53 expression [54].

IGF-1 not only promotes growth of the GI tract [51,53], but protects IECs from oxidative stress, hypoxia, thermal stress and apoptosis in the setting of intestinal injury [55-58]. Moreover, IGF-1 exerts anti-inflammatory properties [59], promotes the development and cytotoxic activity of human NK cells [60], improves intestinal barrier function [61,62] and decreases bacterial translocation [63]. IGF-1 has thus been suggested to play a promising role in the treatment or prevention of necrotizing enterocolitis (NEC) [51,64,65].

IGF1 gene expression is induced by IGF1 P2 promoter demethylation [66-68]. It has been demonstrated that DNMT1 silencing significantly increases the expression of IGF1, whereas DNMT1 up-regulation directly results in hypermethylation of IGF1, thereby reducing IGF-1 expression [69]. It is thus conceivable that MEX-mediated transfer of miRNA-148a, which reduces the expression of DNMT1 in intestinal cells [20,27], may promote intestinal IGF-1 expression [29,30]. Intestinal IGF-1 expression is further promoted by MEX-mediated up-regulation of GRP94 [47], the critical chaperone for IGF-1 synthesis [48]. In accordance, MEX derived from bovine [70], porcine [54], rat [71] and yak milk [72,73] promote proliferation and survival of IECs. Notably, metabolic activity of human colorectal adenocarcinoma epithelial (Caco-2) cells after co-incubation with bovine colostrum and MEX from high immune responder cows was significantly greater than after co-incubation with MEX from low immune responder cows pointing towards immune-genetic variations of MEX bioactivity [74].

\subsection{Intestinal Stem Cells}

The intestinal epithelium is the most rapidly self-renewing tissue in mammals. Leucinerich-repeat-containing G-protein-coupled receptor 5 (LGR5), a WNT target gene with restricted crypt expression, has been identified as marker for intestinal stem cells (ISCs) [75]. LGR5 controls fetal ISC maturation associated with acquisition of a definitive stable epithelial phenotype, as well as the capacity of ISCs to generate their own extracellular matrix [76]. Recent evidence indicates that MEX interact with ISCs. Human MEX exposure to $\mathrm{H}_{2} \mathrm{O}_{2-}$ treated prominin- $1^{+}$ISC s derived from small intestines of the neonatal rat increased ISC viability compared to MEX-free controls [77]. There was a significant up-regulation of mRNA expression of LGR5, axin2, c-myc and cyclin D1 genes of the WNT/ $\beta$-catenin axis in ISCs treated with human MEX as compared to controls [77]. To elucidate the mechanism by which MEX act in promoting cell growth, Hock et al. [71] investigated the gene expression levels of LGR5 in rat IEC-18 cells after incubation with rat MEX. In comparison to controls, there was a significant up-regulation of LGR5 expression in IECs treated with MEX [71]. Thus, MEX promote ISC activity, a critical mechanism for the development and maturation of the intestine during the postnatal breastfeeding period.

\subsection{Intestinal Epithelial Barrier Function}

\subsubsection{Tight Junctions}

The intestinal epithelium establishes a selectively permeable barrier that supports nutrient absorption and waste secretion while preventing intrusion by luminal materials. Intestinal epithelia play a central role in regulating interactions between the mucosal immune system and luminal contents, which include dietary antigens, a diverse intestinal microbiome and pathogens [78]. The appropriate maturation of the intestinal permeability barrier is of critical importance for the neonate and is often immature in preterm infants, who are at increased risk for developing NEC associated with disrupted tight junctions 
(TJs) $[79,80]$. The intestinal permeability barrier is regulated by TJs, which are formed between IECs at the most apical areas of the epithelium. Formation of functional TJs is critical for the maintenance of gut permeability and intestinal barrier function [78,81]. TJs regulate the paracellular movement of molecules between the intestinal lumen and subepithelial tissues [78]. The TJ transmembrane proteins occludin, claudins and the cytoplasmic protein zonula occludens 1 (ZO-1) are considered crucial for creating the seal and thus regulate intestinal permeability $[78,82,83]$.

Remarkably, bovine MEX derived from the $100,000 \times g$ ultracentrifugation fraction of commercial cow milk restored the expression of ZO-1, which was diminished by dextran sodium sulfate (DSS) in a DSS-induced murine model of colitis [84]. It has recently been demonstrated that porcine MEX attenuated deoxynivalenol (DON)-induced damage of IECs. Notably, decreased levels of ZO-1, CLDN1 and OCLN mRNA and protein in IPEC-J2 cells and the small intestinal tissues during continuous DON exposures could be significantly rescued by porcine MEX [85]. In accordance, human MEX administration $6 \mathrm{~h}$ prior to induction of experimental NEC, showed milder intestinal tissue injury than controls and had lower levels of pro-inflammatory cytokines and higher levels of epithelial TJ proteins ZO-1, claudin and occludin [86].

\subsubsection{Goblet Cells and Mucus Layer}

The IECs are covered by a thick layer of mucus, which is produced by goblet cells. Mucus serves as the first line of innate host defense and provides a protective barrier that prevents microorganisms and noxious substances from reaching the surface of the epithelium $[87,88]$. Major components of mucus, the mucins are highly O-glycosylated molecules that have gel-like properties $[87,88]$. The human mucin (MUC) family is subdivided into secreted gel-forming mucins and transmembrane mucins. Secreted/gel-forming mucins such as MUC2 are responsible for the formation of the mucus layer over the epithelium, whereas the transmembrane mucins such as MUC1 are poorly understood [87,88]. Mucins are produced and stored in granules in the goblet cell cytoplasm, are transported to the cell surface and are secreted into the lumen from the apical surface of the goblet cell [89]. Mucus in the small intestine forms a diffusion barrier where anti-microbial substances keep the epithelium free from microorganisms [90]. Goblet cells are highly responsive to the signals they receive from the immune system and are also able to deliver antigens from the lumen to dendritic cells (DCs) in the lamina propria [90]. In fact, the small intestinal goblet cells can sample luminal material during mucus secretion and transfer the antigens to lamina propria DCs something that also happens in the colon if bacterial numbers are decreased. This communication with the immune system has tolerogenic effects [90]. Thus, goblet cells and their secreted mucins play a critical role in intestinal barrier function and immune homeostasis. A recent study in neonates suffering from NEC showed a significant decrease in the expression levels of MUC1, MUC2, occludin and ZO-1 as compared to healthy controls [80].

Li et al. [47] investigated the effects of bovine MEX on goblet cell expression in experimental NEC. To study the effect on mucin production, human colonic LS174T cells were cultured and exposed to bovine MEX. Compared to the control, bovine MEX promoted goblet cell activity, as demonstrated by increased mucin production and relative expression levels of goblet cell expression markers trefoil factor 3 (TFF3) and MUC2 [47]. Recently, Tong et al. [91] observed increased intestinal expression levels of MUC2 after oral administration of bovine MEVs. Reproduction of mucins was also observed after adding MEVs and MEX in the DSS-induced model of colitis associated with a restoration of lachnospiraceae and ruminococcaceae [84]. Administration of raw or Holder-pasteurized (HoP) human MEX during experimentally induced NEC in murine intestine organoids was associated with higher number of goblet cells compared to NEC without MEX exposure. Quantification of immunostaining revealed no difference in goblet cell numbers between raw and HoP human MEX. Administration of both raw and HoP human MEX during NEC increased MUC2 mRNA expression [92]. 


\subsubsection{Gut Microbiome}

Among the factors influencing the mucus barrier, the microbiome plays a major role in driving mucus changes [88]. Mucus forms large pores and is penetrable to bacteria and other components, but despite this, in normal situations, the contact between bacteria and the epithelium is limited $[93,94]$. The continuous secretion of mucus and its flow towards the intestinal lumen donates anti-bacterial agents including lysozyme, deleted in malignant brain tumors 1 (DMBT1), immunoglobulin A (IgA), defensins, regenerating islet-derived $3 \gamma(\operatorname{RegIII} \gamma)$ and phospholipase A2-IIA, which all keep bacteria away from the epithelial surface [88,95-97].

Recent evidence underlines that MEX play a significant role in the regulation of the gut microbiome (Figure 2). RegIII $\gamma$, a secreted anti-bacterial lectin, is essential for maintaining a 50-micrometer zone that physically separates the microbiota from the small intestinal epithelial surface. The loss of host-bacterial segregation in $\operatorname{RegIII} \gamma\left(^{(/-}\right)$mice was coupled to increased bacterial colonization of the intestinal epithelial surface and enhanced activation of intestinal adaptive immune responses by the microbiota [98]. Thus, RegIII $\gamma$ is a fundamental mechanism of innate immunity that promotes host-bacterial mutualism by regulating the spatial relationships between microbiota and host [99]. RegIII $\gamma$ expression depends on MyD88-mediated signaling downstream of toll-like receptors and the IL-1 receptor family, which is critically involved in the induction of protective host responses upon infections [100]. Functional expression of MyD88 in IECs protected mice during intestinal infection, which was associated with enhanced epithelial barrier integrity and increased expression of the RegIII $\gamma$ [100]. It has recently been demonstrated that bovine MEVs increased the expression of MyD88 and RegIII $\gamma$ [91]. Furthermore, the expression of GATA4, IgA and sIgA were increased in murine intestine after administration of bovine MEVs, which thus play a significant role in the integrity of the mucus layer and the innate intestinal defense [91]. DMBT1, a component of HM after birth, is up-regulated in HM from mothers with newborns suffering from neonatal infections [101]. It is not yet known whether MEX transport DMBT1, which has been detected in exosomes from human urine-derived stem cells promoting wound repair [102].

MEX not only interact with IECs, ISCs and goblet cells, but also shape the intestinal microbiome $[103,104]$. In fact, bovine MEX have been shown to alter bacterial gene expression promoting the growth of Escherichia coli K-12 MG1655 and Lactobacillus plantarum WCFS1 [103]. At the operational taxonomic units (OTU) level, four OTUs from the family of lachnospiraceae were more than two times more abundant in mice fed a bovine MEX/RNA-sufficient diet compared to mice fed a bovine MEX/RNA-deficient diet at age 7 and 47 weeks, respectively [104]. Notably, lachnospiraceae, which are butyrate-producing intestinal bacteria [105-107], exhibit reduced abundance in ulcerative colitis [108]. Remarkably, children with lower risk of IgE-mediated allergic diseases showed an earlier maturation of gut microbiota and an increased abundance of butyrate-producing bacteria, associated with earlier maturation of regulatory $\mathrm{T}$ (Treg) cells and lower IgE production [109]. The increase in highly activated Treg cells was associated with a relative abundance of Bifidobacterium longum followed by increased colonization with butyrateproducing bacteria [109]. 


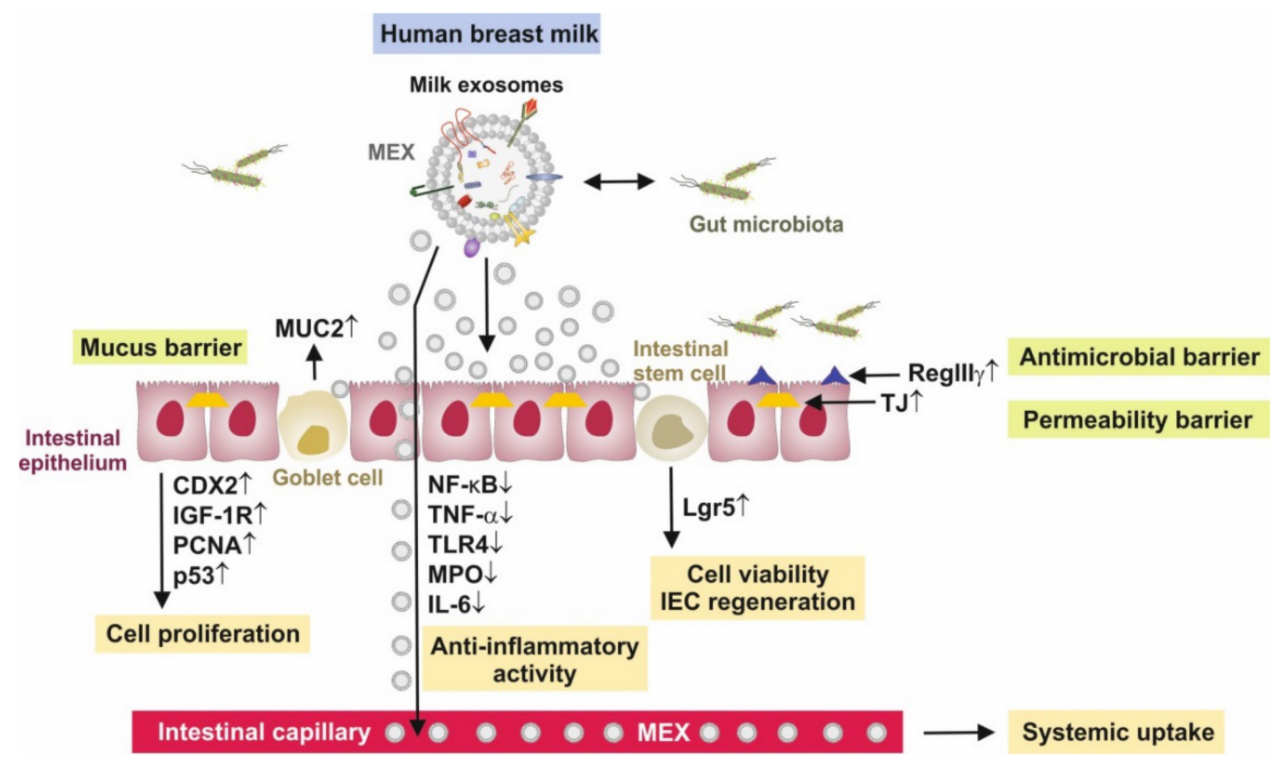

Figure 2. Synopsis of intestinal effects of milk exosomes (MEX). MEX increase intestinal epithelial cell proliferation, goblet cell proliferation and activity and enhance the activity and viability of intestinal stem cells with up-regulation of the stem cell marker leucine-rich-repeat-containing G-protein-coupled receptor 5 (Lgr5). MEX support the formation of the mucus barrier and increase the production of mucin 2 (MUC2), and exert anti-inflammatory activities via the suppression of nuclear factor $\mathrm{\kappa B}$ signaling, tumor necrosis factor- $\alpha$ (TNF- $\alpha$ ), toll-like receptor 4 (TLR4), myeloperoxidase (MPO) and interleukin 6 (IL-6). Furthermore, MEX support the anti-microbial barrier via up-regulation of the anti-bacterial lectin regenerating islet-derived $3 \gamma(\operatorname{RegIII} \gamma)$ and induce the expression of tight junction (TJ) proteins zonula occludens 1, claudin and occludin. Furthermore, MEX directly interact with bacteria of the gut microbiome.

\subsection{Lamina Propria Regulatory T Cells}

Treg cells are characterized by the expression of the master transcription factor forkhead box P3 (FOXP3) [110]. Intestinal Treg cells are crucial to maintain immune tolerance to dietary antigens and gut microbiota [111]. They are critical for tuning the intestinal immune response to self- and non-self-antigens in the intestine [112]. Human infants exhibit presence of mucosal FOXP3 ${ }^{+}$Treg cells in the small and large intestinal mucosa at birth and as early as 23 weeks of gestational age [113]. Gut-resident FOXP3 ${ }^{+} \mathrm{CD}^{+}$ Treg cells are distinct from those in other organs and have gut-specific phenotypes and functions. The differentiation, migration and maintenance of intestinal Treg (iTreg) cells are controlled by specific signals from the local environment [114]. Intestinal tolerance requires gut homing and expansion of FOXP3 ${ }^{+}$Treg cells in the lamina propria [115]. Antigen can be acquired directly by intestinal phagocytes, or pass through enterocytes or goblet cell-associated passages prior to capture by DCs in the lamina propria. Mucin from goblet cells acts on DCs to render them more tolerogenic. A subset of regulatory DCs expressing CD103 is responsible for delivery of antigens to the draining lymph node and induction of Treg cells [116]. The equilibrium between phenotypic plasticity and stability of Treg cells is defined by the fine-tuned transcriptional and epigenetic events required to ensure stable expression of FOXP3 in Treg cells [117,118].

\subsubsection{Epigenetic Regulation of FOXP3 Expression}

Importantly, DNA demethylation regulates stable FOXP3 expression associated with selective demethylation of an evolutionarily conserved element within the FOXP3 locus named TSDR (Treg-specific demethylated region) [117-121]. In CD4 ${ }^{+} \mathrm{T}$ cells, the DNA methyltransferases DNMT1 and DNMT3b reside within the FOXP3 locus and function to methylate $\mathrm{CpG}$ residues, thereby repressing FOXP3 expression in $\mathrm{CD}^{+}$cells, whereas complete demethylation of this site is required for stable FOXP3 expression [122]. Epige- 
netic regulation of FOXP3 can be predictably controlled with DNMT inhibitors to generate functional, stable and specific Treg cells [123].

Immune-modulatory exosomal miRNA-148a-3p, along with miRNA-30b-5p, miRNA182-5p and miRNA-200a-3p, have been designated as major immune-related miRNAs of HM [32]. MEX-derived miRNA-148a via suppressing DNMT1 might increase FOXP3 expression and intestinal $\mathrm{FOXP3}^{+}$Treg cell differentiation as postulated earlier [124,125]. Exosomes play a pivotal role in important aspects of immune regulation and signaling between various cells of the immune system $[126,127]$, especially in inflammatory bowel diseases [128,129]. In a dose-dependent manner, Admyre et al. [130] observed increased numbers of FOXP3 ${ }^{+} \mathrm{CD}^{+} \mathrm{CD} 25^{+}$Treg cells in peripheral blood mononuclear cells (PBMC) incubated with human MEX. In accordance, rat pups exposed to $\beta$-lactoglobulin (BLG), one of the main allergenic proteins in cow milk, in the presence of maternal rat milk developed an immune response profile similar to that of unchallenged dam-reared rats associated with a greater FOXP3 expression and increased numbers of FOXP3 ${ }^{+} \mathrm{CD} 4^{+} \mathrm{T}$ cells [131]. In accordance, FOXP3 TSDR demethylation was significantly lower in children with active IgE-mediated cow milk allergy (CMA) than in healthy children or those who outgrew CMA [132]. Constitutive $\mathrm{CD} 4^{+} \mathrm{CD} 25^{+}$Treg cells alleviated clinical signs of immediate type hypersensitivity to dietary BLG by modulating the priming of BLG-specific $\mathrm{T}$ and $\mathrm{B}$ cell responses during oral sensitization [133]. Furthermore, FOXP3 methylation was increased in peanut extract-sensitized and challenged mice pups, whereas in tolerized mice levels were significantly reduced [134]. Treg cells themselves are able to secrete miRNAcontaining exosomes. Treg cells via exosome release transfer miRNAs, including let-7d, let-7b and miRNA-155, to conventional T cells. Notably, Treg cell-derived exosomal let-7d, an immune-regulatory miRNA found in human MEX [32], suppresses pathogenic T helper 1 cells [135]. Thus, FOXP3 demethylation and consecutive Treg cell differentiation are associated with tolerance induction. MEX-mediated miRNA-148a-DNMT1 signaling may thus control the development of oral tolerance, a meaningful mechanism during weaning and the introduction of external solid foods.

Remarkably, increased Treg cell numbers are associated with raw farm milk exposure and lower atopic sensitization and asthma in childhood [136]. Of note, the protective effect of farm milk consumption on childhood asthma and atopy was lost when boiled farm milk was consumed instead of raw cow milk, pointing to a heat-labile protective factor in milk $[137,138]$. There is evidence that vigorous heat-treatment such as ultraheat-treatment (UHT: $\left.135^{\circ} \mathrm{C},>1 \mathrm{~s}\right)$ and boiling $\left(100{ }^{\circ} \mathrm{C}\right)$ of commercial cow milk destroys MEVs and MEX and their miRNA cargo, including miRNA-148a [139,140], whereas pasteurization $\left(72-78{ }^{\circ} \mathrm{C},>15 \mathrm{~s}\right)$ of commercial milk did not affect total MEV numbers and preserved nearly $25-40 \%$ of milk's total small RNAs, including miRNA-148a [139]. In comparison to high pressure processing of $\mathrm{HM}, \mathrm{HoP}$ of $\mathrm{HM}\left(62.5^{\circ} \mathrm{C}, 30 \mathrm{~min}\right)$ resulted in a significant decrease in MEX numbers [22].

Thus, early-life exposure to unpasteurized milk may protect against atopy, asthma and related conditions, independently of the place of residence and farming status, in both children and adults [141]. HM and unprocessed farm milk may enhance DNMT1dependent stable Treg cell maturation. A recent randomized controlled trial showed that preterm neonates who received bovine colostrum had higher FOXP3 Treg cell levels compared to controls [142].

\subsubsection{Transforming Growth Factor $\beta$ and FOXP3 Expression}

Interleukin 2 (IL-2) and transforming growth factor- $\beta 1$ (TGF- $\beta 1$ ) also play a central role in Treg cell homeostasis. Naïve T cells after in vitro stimulation in the presence of TGF- $\beta$ and IL-2 differentiate into iTreg cells [143-145]. Importantly, T cell receptor (TCR) and TGF- $\beta$ signaling converge on DNMT1 to control FOXP3 methylation and iTreg cell differentiation [146]. TCR activation causes the accumulation of DNMT1 and DNMT3b and their specific enrichment at the FOXP3 locus, which leads to increased CPG methylation inhibiting FOXP3 transcription. During this process, the augmentation 
of DNMT1 is regulated through at least two post-transcriptional mechanisms. Strong TCR signal inactivates glycogen synthase kinase 3 (GSK3) to rescue DNMT1 protein from proteasomal degradation and suppresses miRNA-148a to derepress DNMT1 mRNA translation [146]. In contrast, TGF- $\beta$ signaling antagonizes DNMT1 accumulation via activation of p38 MAP kinase [146]. Interestingly, commercial cow milk contains MEX expressing immune-regulatory TGF- $\beta$ [147]. In the DSS-induced murine colitis model, administration of human MEX down-regulated DNMT1 and DNMT3, whereas TGF- $\beta$ was up-regulated in the colon [148]. TGF- $\beta 2$ is significantly up-regulated in human MEX during weaning/early involution [149]. TGF- $\beta$ in colostrum may prevent the development of atopic disease during exclusive breastfeeding and promote specific IgA production in human subjects [150]. Of note, TGF- $\beta 1$ was significantly less secreted into mature milk of allergic mothers compared to non-allergic mothers [151].

miRNA-155 is another miRNA necessary for the development of Treg cells [152,153]. Notably, miRNA-155 is highly expressed in human and bovine milk $[154,155]$. miRNA155 via targeting signal transducer and activator of transcription 1 (SOCS1) may activate IL-2/STAT5 signaling which promotes Treg cell development $[156,157]$. Both FOXP3 and TGF- $\beta$ increase the expression of miRNA-155 $[152,158,159]$, which plays a key role in the activation and differentiation of iTreg and thymic Treg (tTreg) cells [152,153].

Recent evidence indicates that the expression of uncoupling protein 3 (UCP3) is involved in the regulation of Treg cells [160]. When compared to $\mathrm{UCP}^{+/+}$mice, $\mathrm{CD}^{+} \mathrm{T}$ cells from $\mathrm{UCP3}^{-/-}$mice had increased FOXP3 expression under iTreg cell conditions [160]. Notably, UCP3 is a direct target of miRNA-148a. MEX via transfer of miRNA-148a, miRNA155 and TGF- $\beta$ synergistically stimulate Treg differentiation, inducing and maintaining a tolerogenic intestinal environment that reduces the risk of intestinal inflammation and allergic sensitization [124,125].

\subsection{Anti-Inflammatory Action of Milk Exosomes}

It has been demonstrated in various experimental models of NEC that the addition of human, bovine and porcine MEX attenuated the expression of inflammatory cytokines such as interleukin 6 (IL-6), interleukin $1 \beta$ (IL-1 $\beta$ ) and tumor necrosis factor- $\alpha$ $($ TNF- $\alpha)[84,92,148,161,162]$, TLR4 [162,163] and nuclear factor кB (NF-kB) [162]. Previous studies showed that miRNA-146a, miRNA-155, miRNA-125b and miRNA-21, abundant immune-regulatory miRNAs of human and bovine milk and MEX [14,22,25,32,164], inhibit TLR-triggered production of inflammatory cytokines [165-169].

In phagocytes, changes in cytosolic $\mathrm{Ca}^{2+}$ regulate receptor-mediated endocytosis, phagosome-lysosome fusion and antigen processing. Calcium/calmodulin-dependent protein kinase II $\alpha$ (CaMKII $\alpha)$, is an important regulator of the maturation and function of DCs [170]. There is recent evidence that miRNAs are critically involved in the regulation of DC differentiation and function [171]. Importantly, miRNA-148a targets the mRNA of $C A M K 2 A$, the gene encoding CaMKII $\alpha$ [172]. In fact, miRNA-148a-mediated inhibition of CaMKII $\alpha$ inhibited the production of cytokines including IL-12, IL-6, TNF- $\alpha$ and IFN- $\beta$ up-regulation of MHC class II expression and DC-initiated antigen-specific T cell proliferation [172]. CaMKII inhibitors blocked the antigen-induced increase in total cellular MHC class molecules as well as their trafficking to the plasma membrane, which was associated with decreased presentation of particulate and soluble MHC class II-restricted antigen $[170,173]$. CaMKII has been identified as an activator of IKB kinase (IKK) specifically in response to TCR stimulation [174]. CaMKII is critically involved in TCR signaling and CARD-containing MAGUK protein 1 (CARMA1)-induced NF- $\mathrm{kB}$ activation [175]. CaMKII-mediated phosphorylation of CARMA1 may play a key role in TCR-mediated NF- $\mathrm{KB}$ activation [175].

Furthermore, miRNA-148a was found to be a direct repressor of IKB kinase $\beta$ (IKK $\beta$ ) encoded on IKBKB [176]. IKK $\beta$ is a key regulator of NF- $K B$ signaling. IKK $\beta$ via phosphorylation of $I \kappa B$ results in dissociation of I $\kappa B$ from NF- $\kappa B$ allowing NF- $\kappa B$ translocation to the nucleus, which induces the synthesis of pro-inflammatory cytokines [177]. Appar- 
ently, MEX-derived miRNA-148a, miRNA-146a, miRNA-155, miRNA-125b and miRNA-21 in a synergistic fashion negatively regulate the activation of immune cells and prevent over-activation of immune responses. MEX miRNA-148a-mediated suppression NF- $\mathrm{B}$ signaling may play a key role in the regulation of immune homeostasis and intestinal inflammation [178].

Of note, FOXP3, which is up-regulated by miRNA-148a-mediated suppression of DNMT1 [124,125], physically associates with the Rel family transcription factors, nuclear factor of activated T cells (NFAT) and NF- $k B$, and blocks their ability to induce the endogenous expression of key pro-inflammatory cytokine genes [179,180]. Thus, miRNA-148a, the most abundant miRNA of HM and MEX [22], interrupts NF- $\kappa B$ signaling at multiple immune-regulatory checkpoints: CaMKII, IKK $\beta$ and FOXP3 (Figure 3). As the crucial inhibitory effect of glucocorticoids on NF- $\mathrm{B}$ signaling relies on the induction of I $\mathrm{B}$, which traps activated NF- $\mathrm{KB}$ in inactive cytoplasmic complexes [181-183], MEX-derived miRNA148a operates in a synergistic fashion with corticosteroids maintaining high cellular levels of $\mathrm{I} \kappa \mathrm{B}$ that attenuates pro-inflammatory NF- $\mathrm{KB}$ signaling.

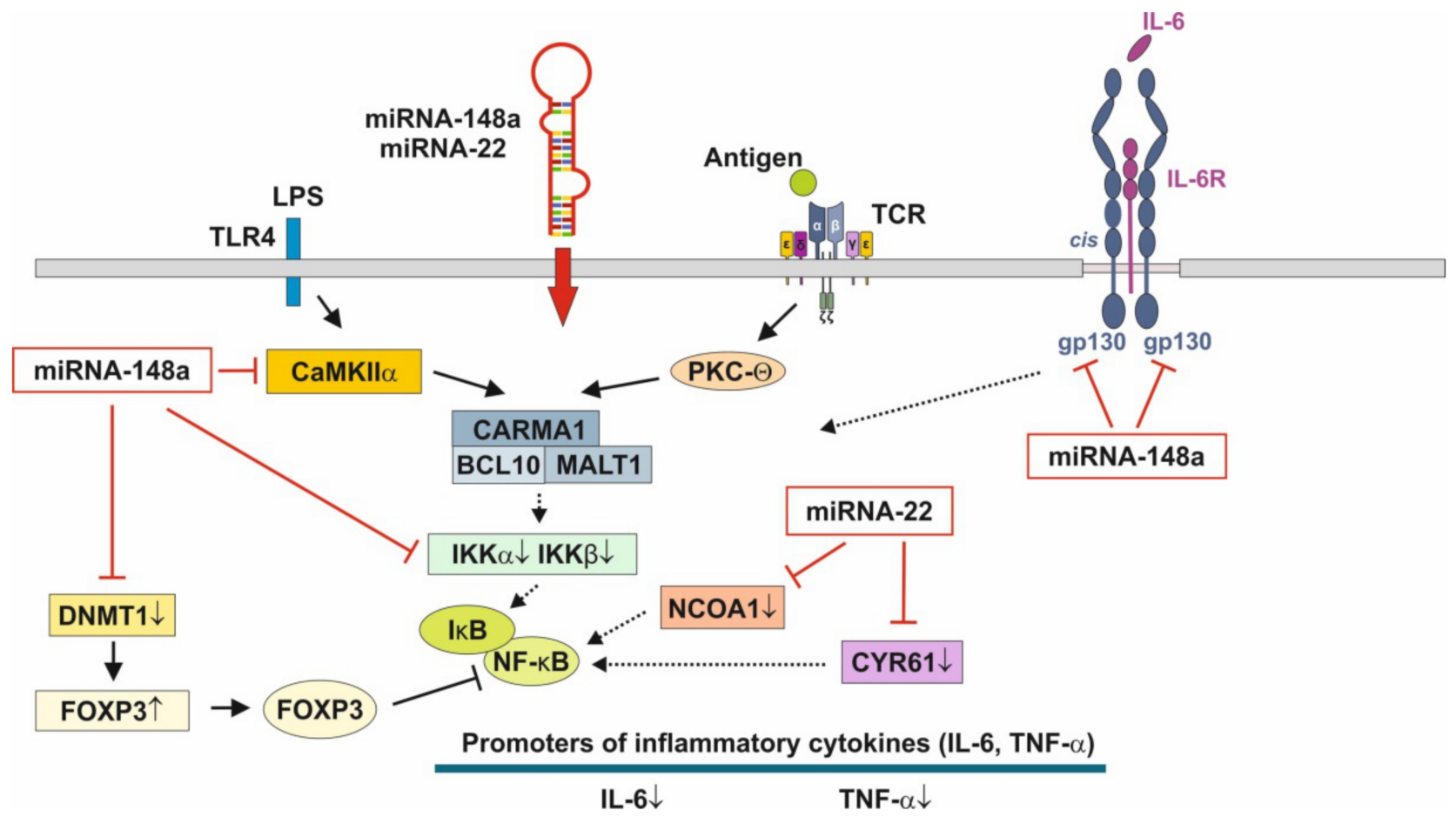

Figure 3. Anti-inflammatory actions of miRNA-148a and miRNA-22 on nuclear factor $\kappa \mathrm{B}$ signaling. miRNA-148a via suppression of DNA methyltransferase 1 (DNMT1) enhances the expression of FOXP3, which is a negative regulator of nuclear factor $\mathrm{\kappa B}$. miRNA-148a directly targets calcium/calmodulin-dependent protein kinase II $\alpha(\mathrm{CaMKII} \alpha)$, which phosphorylates CARD-containing MAGUK protein 1 (CARMA1) involved in the activation of IkB kinase $\alpha$ (IKK $\alpha$ ) and I $\mathrm{B}$ kinase $\beta$ (IKK $\beta$ ), Notably, miRNA-148a directly targets IKK $\alpha$ and IKK $\beta$, thereby enhancing the inhibitory effect of IKB on NF- $\kappa$ B. In addition, miRNA-148a targets the interleukin 6 (IL-6) signal transducer gp130. miRNA-22, which is highly expressed in preterm MEX, targets nuclear receptor co-activator 1 (NCOA1) and cystein-rich protein 61 (CYR61), which both activate NF- $\mathrm{kB}$. miRNA-30b via targeting RIP140 suppresses IL-6 expression. MEX-derived miRNAs thus provide anti-inflammatory signaling.

\subsection{Adaptive Maternal Responses of Milk Exosomes in Preterm Infants}

The expression of miRNAs in the lipid and skim milk fractions of preterm HM differs significantly from term HM fractions one month after delivery. Carney et al. [184] reported nine miRNAs "altered" across both fractions and these miRNAs target a number of transcripts involved in metabolic processes. The pathway with the most significant enrichment in miRNA targets from preterm HM is glycosphingolipid biosynthesis [184], 
which is important for neurodevelopment, membrane function and signal transduction of lipid rafts [184]. Kahn et al. [15] demonstrated significant differences in MEX miRNA composition between the $\mathrm{HM}$ of mothers delivering preterm infants compared to the HM produced for term infants. The abundant miRNAs in preterm MEX are similar to those from term MEX, whereas 21 low abundance miRNAs are specifically expressed in preterm MEX compared to early term MEX [15]. Notably, miRNA-22 is highly expressed in extremely preterm MEX followed by miRNA-148a [15].

miRNA-22 is an evolutionally conserved miRNA that is highly expressed in the heart and plays an important role in cardiac remodeling [185]. Furthermore, miRNA-22 is involved in the regulation of metabolism, energy expenditure and immune functions. Important targets of miRNA-22 are PTEN, purine rich element binding protein B (PURB), caveolin 3 (CAV3), histone deacetylase 4 (HDAC4), peroxisome proliferator-activated receptor- $\gamma$ co-activator $1 \alpha$ (PGC- $1 \alpha)$, peroxisome proliferator-activated receptor- $\alpha$ (PPAR $\alpha)$ and sirtuin 1 (SIRT1), which coordinate fatty acid metabolism, mitochondrial biogenesis and energy homeostasis [186,187]. Loss of miRNA-22 reduces fat mass gain induced by high-fat diet and enhanced energy expenditure $[186,188]$.

miRNA-22 exerts strong anti-inflammatory activities via targeting the mRNA of cysteine-rich protein 61 (CYR61/CCN1) [189], a component of the extracellular matrix, which is produced and secreted by several cell types including endothelial cells, fibroblasts and smooth muscle cells. miRNA-22 directly targets the $3^{\prime}$-untranslated ( $\left.3^{\prime} \mathrm{UTR}\right)$ region of the messenger RNA of CYR61 [189] and has been implicated in leukocyte migration and inflammation (Figure 3) [190]. miRNA-22 was found to be one of the most significantly up-regulated miRNAs in LPS-stimulated RAW264.7 macrophages after treatment with simvastatin [191]. CYR61 was mainly up-regulated in intestinal mucosa after intestinal ischemia/reperfusion injury in pigs [192]. In addition, miRNA-22 attenuates myocardial ischemia-reperfusion injury via an anti-inflammatory mechanism in rats [193] and via targeting CREB binding protein (CBP) protects against myocardial ischemia-reperfusion injury through anti-apoptosis in rats [194].

It has been demonstrated in murine macrophages that CYR61 activates NF- $\mathrm{kB}$-mediated transcription, and induces a pro-inflammatory genetic program characteristic of classically activated M1 macrophages that participates in Th1 responses. The effects of CYR61 include up-regulation of TNF- $\alpha$, IL- $1 \alpha$, IL-1 $\beta$, IL- 6 and IL-12b [195]. miRNA-22 over- expression significantly inhibited NF- $\mathrm{KB}$ activity by decreasing nuclear receptor co-activator 1 (NCOA1) expression (Figure 3) [196,197]. Furthermore, miRNA-22 suppresses the function of DCs via targeting p38 mRNA [198]. p38 down-regulation reduced the synthesis of DCderived IL-6 and the differentiation of DC-driven Th17 cells [198]. Thus, over-expressed miRNA-22 in MEX delivered to preterm infants with low birthweight appear to promote growth, weight gain, tissue maturation and attenuates inflammatory responses. This suggests that preterm milk and their MEX-derived miRNAs may have adaptive functions for growth and maturation in premature infants.

circRNAs and lncRNAs are also delivered by human, bovine and porcine MEX, that are stable to in vitro digestion [199-201]. circRNAs have been shown to promote ISC self-renewal [202]. Murine and human Lgr5 $5^{+}$ISCs showed high expression of the immune cell-associated circRNA circPan3 [202]. circRNAs are related to inflammatory bowel disease and intestinal barrier formation [203]. Recent studies have shown that exosomal circRNAs play critical roles in the development of neonatal tissue and organ, such as the brain [204] and the nervous system [205]. Zhou et al. [199] identified 6756 circRNAs both in preterm human colostrum and term colostrum, of which 66 were up-regulated and 42 were downregulated in preterm colostrum. Pathway analysis showed that the vascular epithelial growth factor (VEGF) signaling pathway was involved. In particular, MEX found in preterm colostrum and term colostrum promoted VEGF protein expression and induced the proliferation and migration of small IECs [199]. 
Taken together, the physiological adaptations of colostrum and MEX RNAs in the milk of mothers, who delivered preterm infants, may accelerate intestinal maturation, barrier function and innate immunity, critical factors for the prevention of NEC.

\section{Necrotizing Enterocolitis}

\subsection{Pathogenesis}

Necrotizing enterocolitis (NEC), which mostly affects premature neonates, is a lifethreatening inflammatory intestinal disease that can result in sepsis, multiorgan failure, short gut syndrome, which requires long-term intravenous nutrition, subsequent liver damage and death [206-208]. Prematurity, formula feeding [209], systemic stress, sepsis, hypoxia [209], aberrant microbiome (dysbiosis) [210,211], deviated innate immunity with exaggerated NF- $\kappa B$ signaling $[210,212,213]$, intestinal ischemia and necrosis and gut barrier disruption [214] all lead to fulminant organ failure. Prematurity and formula feeding have been emphasized as major risk factors for NEC [209]. Formula feeding and immature gut microcirculation promote intestinal hypoxia promoting NEC. One of the most important pathways that mediates the balance between injury and repair in the premature intestine, and that plays a key role in NEC pathogenesis, is TLR4, which recognizes lipopolysaccharide (LPS) on Gram-negative bacteria [215]. TLR4 promotes NEC by inducing inflammation, inhibiting enterocyte proliferation and reducing intestinal microcirculation [216,217]. Indeed, formula feeding and systemic hypoxia synergistically induced intestinal hypoxia in experimental NEC [218]. TLR4-dependent Th17 polarization was required for NEC development, as inhibition of STAT3 or IL-17 receptor signaling attenuated NEC in mice, while IL-17 release impaired enterocyte TJs, increased enterocyte apoptosis and reduced enterocyte proliferation, leading to NEC [216]. Recently, a higher proportion of CCR9 ${ }^{+}$ $\mathrm{CD}^{+} \mathrm{T}$ cells occurred in peripheral blood of both patients and mice with NEC as compared to controls [219]. Elevated CCR9 ${ }^{+} \mathrm{CD}^{+}{ }^{+} \mathrm{T}$ cells were primarily CCR9 ${ }^{+}$IL-17-producing Treg cells, possessing features of conventional Treg cells, but their suppressive activity was seriously impaired and negatively correlated with the severity of intestinal tissue injury. IL-6 promoted polarization of CCR9 ${ }^{+}$Treg cells to CCR9 ${ }^{+}$IL-17-producing Treg cells, and blocking IL-6 signaling inhibited this conversion in vitro and ameliorated experimental NEC in vivo [219]. With or without LPS stimulation, monocytes from NEC infants presented elevated TNF- $\alpha$ and IL-6 expression, together with reduced expression of TGF- $\beta$ [220]. When incubated with autologous $\mathrm{CD}^{+} \mathrm{T}$ cells, monocytes from NEC infants preferentially promoted the differentiation of ROR $\gamma$ t-expressing Th17 cells, but not FOXP3-expressing Treg cells [220]. However, using exogenous TGF- $\beta$ and IL-10, the development of FOXP3 expression could be significantly elevated [220]. Notably, a paucity of IL-10 in HM was found in mothers, whose infants developed NEC [221]. TGF- $\beta$, a strong immune suppressor and a constituent in HM and MEX [147,222], has been shown to be protective against NEC [223]. TGF- $\beta 1$ suppressed NF- $\kappa B$ activation, maintained levels of the NF- $\kappa B$ inhibitor $I \kappa B \alpha$ in the intestinal epithelium and systemically decreased serum levels of IL-6 and IFN- $\gamma$ [223]. HM feedings, both from maternal and human donor milk, have been associated with reductions in NEC in preterm infants [224]. Among the various NEC-protective factors delivered by HM, MEX appear to play a dominant role.

\subsection{Milk Exosomes in Experimental Necrotizing Enterocolitis}

While no animal model perfectly mimics human NEC, each has greatly improved our understanding of this serious disease [225]. Nutritional modulation of the gut microbiota and immune system in preterm neonates susceptible to NEC is important for the prevention and treatment of NEC [224,226,227]. In fact, HM is the highly recommended feeding strategy to prevent NEC $[227,228]$. There is recent interest in the role exosomes for intestinal mucosal immunity and inflammatory bowel diseases [229]. Particularly, MEX have emerged as key players in the pathogenesis, prognosis, prevention and treatment of NEC [230]. Human, bovine and porcine MEX have been administered in various intestinal models (IECs, rodent intestine, intestinal organoids, genetically induced colitis) and prior, 
during or after several types of cell injury such as oxidative stress (hydrogen peroxide), hypoxia, hyperosmolar formula, mucosa cell toxins (dioxynivalenol, dextran sulfate sodium) and inflammatory agents such as lipopolysaccharides (LPS). Table 1 presents an overview of the biological outcomes of MEX administration in various colitis and NEC models.

Table 1. Biological effects of milk-derived exosomes (MEX) in colitis and NEC models.

\begin{tabular}{|c|c|c|c|c|}
\hline Model & $\begin{array}{l}\text { MEX } \\
\text { Source }\end{array}$ & Insulting Agents & Biological Effects & References \\
\hline IEC-6 cells & Human & $\mathrm{H}_{2} \mathrm{O}_{2}$ & Increased cell viability; protection from oxidative stress & {$[231]$} \\
\hline IEC-6 & Yak, Cow & Hypoxia & $\begin{array}{l}\text { Yak-MEX increased survival of IEC-6 cells compared } \\
\text { with bovine-MEX; yak-MEX promote oxygen-sensitive } \\
\text { prolyl hydroxylase (PHD)-1 expression and decrease } \\
\text { HIF- } \alpha, \text { VEGF and p53 }\end{array}$ & {$[72]$} \\
\hline IEC & Porcine & LPS & $\begin{array}{l}\text { Decreased LPS-induced TLR4/NF- } \mathrm{BB} \text { signaling } \\
\text { pathway activation; reduced LPS-induced apoptosis via } \\
\text { the p53 pathway }\end{array}$ & [162] \\
\hline $\begin{array}{l}\text { IEC } \\
\text { murine intestine }\end{array}$ & Porcine & Deoxynivalenol & $\begin{array}{l}\text { Up-regulation of miRNA-181a, miRNA-30c, } \\
\text { miRNA-365-5p and miRNA-769-3p in IPEC-J2 cells; } \\
\text { suppression of p53 pathway; increased proliferation } \\
\text { and TJs; inhibition of apoptosis }\end{array}$ & [85] \\
\hline $\begin{array}{l}\text { Premature } \\
\text { Sprague-Dawley rat } \\
\text { pups; IEC-6 cells }\end{array}$ & Human & $\begin{array}{l}\text { Asphyxia, } \\
\text { hypothermia, } \\
\text { hypercaloric feed, } \\
\text { hypoxia }\end{array}$ & $\begin{array}{l}\text { Decrease in histological NEC grade; increased IEC cell } \\
\text { proliferation; decreased apoptosis of IEC }\end{array}$ & [232] \\
\hline $\begin{array}{l}\text { Prominin- } 1^{+} \text {ISCs of } \\
\text { small intestines of } \\
\text { neonatal rat }\end{array}$ & Human & $\mathrm{H}_{2} \mathrm{O}_{2}$ & $\begin{array}{l}\text { Increase in ISC viability; increased expression of LRG5, } \\
\text { axin2, c-myc, cyclin D1, HES1, DII1, DII4 }\end{array}$ & [77] \\
\hline $\begin{array}{l}\text { LS174T human colonic } \\
\text { cells; C57BL/6 mice }\end{array}$ & Bovine & $\begin{array}{l}\text { Hypoxia, } \\
\text { hyperosmolar } \\
\text { formula, LPS }\end{array}$ & $\begin{array}{c}\text { Increased goblet cell numbers and mucin production; } \\
\text { Increased expression trefoil factor } 3 \text { (TFF3) and mucin } 2 \\
\text { (MUC2). Enhanced the expression of glucose-regulated } \\
\text { protein } 94 \text { (GRP94) }\end{array}$ & [47] \\
\hline C57BL/6J mice & Bovine & $\begin{array}{l}\text { Dextran sulfate } \\
\text { sodium }\end{array}$ & $\begin{array}{l}\text { Decreased inflammation through the down-regulation } \\
\text { of colitis-associated miRNAs, especially miRNA-125b, } \\
\text { associated with a higher expression of the NF-kB } \\
\text { inhibitor TNFAIP3 }\end{array}$ & {$[84]$} \\
\hline $\begin{array}{l}\text { Newborn } \\
\text { Sprague-Dawley rat } \\
\text { pups; human intestinal } \\
\text { epithelial FHC }\end{array}$ & $\begin{array}{l}\text { Human, } \\
\text { term/preterm }\end{array}$ & $\begin{array}{l}\text { Hypoxia } \\
\text { formula }\end{array}$ & $\begin{array}{l}\text { Preterm MEX significantly enhanced proliferation and } \\
\text { migration of IECs compared with term MEX }\end{array}$ & [233] \\
\hline $\begin{array}{l}\text { Intestinal organoids; } \\
\text { C57BL/ } 6 \text { mice pups }\end{array}$ & Human & LPS & Decreased expression of TNF- $\alpha$ and TLR4 & {$[163]$} \\
\hline Balb/c mice & Human & $\begin{array}{l}\text { Dextran sulfate } \\
\text { sodium }\end{array}$ & $\begin{array}{l}\text { MEX attenuated the severity of colitis induced by DSS } \\
\text { and statistically reduced the histopathological scoring } \\
\text { grade and shortening of the colon; reduced expression } \\
\text { of IL-6, TNF- } \alpha \text {, DNMT1 and DNMT3; up-regulation of } \\
\text { TGF- } \beta\end{array}$ & [148] \\
\hline $\begin{array}{l}\text { Mdr1 } 1 a^{-/-} \text {mice } \\
\text { (5 weeks old) }\end{array}$ & Bovine & $\begin{array}{l}\text { 60\% MEX-deficient } \\
\text { diet }\end{array}$ & $\begin{array}{l}\text { Higher degree of intestinal lesions; deficiency of } \\
\text { miRNA-200a-3p targeting Cxcl9 mRNA }\end{array}$ & {$[234]$} \\
\hline $\begin{array}{l}\text { Intestine of kindlin } 2 \\
\text { knockout mice }\end{array}$ & Bovine & Kindlin 2 knockout & $\begin{array}{l}\text { Decrease in macroscopic colitis score in MEX-treated } \\
\text { mice compared with untreated mice }\end{array}$ & [235] \\
\hline $\begin{array}{l}\text { Intestinal organoids of } \\
\text { C57BL/ } 6 \text { mouse pups }\end{array}$ & Human & $\begin{array}{l}\text { Hypoxia } \\
\text { formula, LPS }\end{array}$ & $\begin{array}{c}\text { Decreased IL-6 mRNA expression; decreased injury } \\
\text { score and MPO activity; increase in goblet cell number } \\
\text { and MUC2 mRNA expression }\end{array}$ & [92] \\
\hline
\end{tabular}

MEX have been demonstrated to protect IECs from oxidative stress $[77,231]$ and hypoxia $[47,72,232,233]$, stimulate ISC activity [77], improve the proliferation and migration of IECs $[72,148,162]$, improve intestinal barrier function and mucin production $[85,92,234]$, reduce intestinal inflammation $[84,92,162,163,235]$ and lower the incidence and severity of experimental NEC $[84,85,92,148,163,235]$. Importantly, MEX-derived miRNA-148a and 
miRNA-22, two major miRNAs of colostrum and mature HM, attenuate the inflammatory cascade at critical checkpoints.

\subsection{Anti-Inflammatory Action of miRNA-148a, miRNA-22 and miRNA-30b}

miRNA-148a attenuates NF-kB signaling at various regulatory checkpoints (Figure 3). Decreased expression of miRNA-148a has been demonstrated in LPS-stimulated endometrial epithelial cells, where TLR4 has been identified as a direct target of miRNA-148a [236]. In this model, over-expression of miRNA-148a using agomiR markedly reduced the production of pro-inflammatory cytokines, such as IL-1 $\beta$ and TNF- $\alpha$, and suppressed NF- $k B$ p65 activation by targeting the TLR4-mediated pathway [236]. Remarkably, Zhu et al. [237] demonstrated that miRNA-148a inhibits colitis and colitis-associated tumorigenesis in mice. miRNA-148a is down-regulated in human inflammatory bowel disease (IBD) and colorectal cancer (CRC) patient tissues [237]. Of note, miRNA-148a-3p negatively regulates CRC tumor cell PD-L1 expression. Decreased levels of miRNA-148a-3p have been associated with an immunosuppressive tumor microenvironment [238]. Drastically reduced miRNA-148a-3p/5p expression was observed in the colons after DSS treatment of mice [237]. miRNA-148a directly targets several well-accepted upstream regulators of NF- $\mathrm{KB}$ and STAT3 signaling, including GP130, IKK $\alpha$, IKK $\beta$, IL1R1 and TNFR2, which leads to decreased NF- $\mathrm{KB}$ and STAT3 activation in macrophages and colon tissues [237]. GP130, also known as IL-6 signal transducer [239], is conserved in the IL-6 family of cytokines [240] and plays a key role in pro-inflammatory IL-6/GP130-STAT3 signaling (Figure 3) [241,242].

The nuclear receptor-interacting protein 140 (RIP140) promotes the activity of NF- $\mathrm{kB}$ and up-regulates the expression of pro-inflammatory genes such as TNF- $\alpha$ and IL-6 [243]. The function of RIP140 as a co-activator for cytokine gene promoter activity relies on direct protein-protein interactions with the NF- $\kappa$ B subunit RelA and histone acetylase cAMPresponsive element binding protein (CREB)-binding protein (CBP) [243]. Of importance, miRNA-30b-5p, a key immune-regulatory miRNA of human MEX [32], targets the 3'UTR region of the mRNA of RIP140 (NRIP1) [244], thus attenuates pro-inflammatory action of NF-kB.

These findings reveal that miRNA-148a exerts strong anti-inflammatory activities and is an indirect tumor suppressor that modulates colitis and colitis-associated tumorigenesis by suppressing the expression of signaling by NF- $\mathrm{kB}$ and STAT3 and their pro-inflammatory consequences. In contrast to prostate cancer [245-248], commercial milk consumption has been epidemiologically associated with a reduced risk of colon cancer [249-251]. Notably, up-regulated expression of miRNA-148a has been detected in prostate cancer tissue [252], whereas reduced expression of miRNA-148a is a hallmark of colon cancer [253,254]. In contrast to the anti-inflammatory effects of MEX, recently identified bovine meat and milk factors (BMMFs), which are small episomal DNA molecules isolated from milk also from colon cancer tissue, were related to local chronic intestinal inflammation promoting CRC $[255,256]$.

Reif et al. [27] demonstrated that human MEX entered CCD841 normal colon epithelial cells (CCD841) and colonic cancer cells (LS123) and increased intracellular miRNA-148a levels. In contrast to colonic tumor cells, MEX stimulated proliferation of CCD841 normal colon epithelial cells under starvation conditions [27].

MEX-mediated attenuation of the severity of DSS-induced colitis associated with a reduced the histopathological scoring grade and reduced expression of IL-6 and TNF- $\alpha$ [148] may be well explained by the anti-inflammatory action of MEX-derived miRNA-148a.

\subsection{Hormonal Regulation of MiRNA-148a Expression}

There is recent interest in the use of melatonin in oxidative stress-related neonatal diseases including NEC [257-260]. Highest melatonin concentrations were detected in colostrum, followed by transitional and mature HM [261]. Notably, melatonin ameliorates NEC in a neonatal rat model decreasing TNF- $\alpha$ and IL-1 $\beta$ [262]. Recent evidence in an NEC mouse model indicates that melatonin treatment ameliorates inflammation and 
improves intestinal Th17/Treg cell balance [263]. It has recently been demonstrated in MDA-MB-231 cells that melatonin increased the expression of miRNA-148a [264]. Thus, maternal melatonin may modify the expression of anti-inflammatory miRNA-148a in MEX, a potentially supportive effect of melatonin in HM that may induce IEC miRNA-148a expression.

Lactogenic hormones also alter cellular and extracellular miRNA expression in MGECs [265]. Dexamethasone, insulin and prolactin induced lactogenic differentiation of bovine MGECs associated with increased expression of miRNA-148a [265].

Oxytocin is another important hormone of perinatal physiology and component of HM [266]. Recent evidence indicates that colostrum oxytocin modulates cellular stress response, inflammation and autophagy markers in newborn rat gut villi [267]. Notably, colostrum increased inactive p-eIF2a, p-PKR and IкB and reduced p-IкB, BiP and LC3A. LPS increased and oxytocin decreased $\mathrm{p}$-I $\mathrm{KB}$ underlining the anti-inflammatory activity of oxytocin on the postnatal gut [267]. In accordance, administration of oxytocin decreased, while the oxytocin receptor antagonist atosiban exacerbated intestinal inflammation in murine experimental model of NEC [268]. It is thus tempting to speculate that oxytocin in concert with melatonin and prolactin may augment MEX miRNA-148a expression.

\subsection{MEX-Mediated Up-Regulation of TNF- $\alpha$-Induced Protein 3}

Increasing densities of Clostridium perfringens have been associated with NEC in preterm infants $[269,270]$. Total bacterial and C. perfringens densities were higher in NEC versus healthy pigs and correlated positively with NEC severity. In IPEC-J2 cells, expression levels of inflammation-related genes (CCL5, NFKBIA, IL8, IL1RN) and TNF- $\alpha$-induced protein 3 (TNFAIP3) increased, while the expression of the sodium/glucose cotransporter (SLC5A1) decreased, with increasing density of $C$. perfringens [271]. It has been demonstrated that $C$. perfringens type $\mathrm{C}$ activates TLR4/MyD88/NF- $\mathrm{KB}$ signaling in piglet small intestines [272]. TNFAIP3, also known as A20, is a deubiquitinase which operates as a key negative regulator of NF- $\mathrm{KB}$ signaling that is essential for maintaining immune homeostasis and down-regulating inflammation [273,274]. Mice lacking A20 specifically in DCs (precolitic A20fl/fl Cd11c-Cre mice) spontaneously developed lymphocyte-dependent colitis and exhibited an increased susceptibility to DSS-induced colitis. Taken together, these results indicate that DCs require A20 to maintain intestinal immune homeostasis and to restrict epithelial damage-triggered colitis [275]. Importantly, Benmoussa et al. [84] observed a significant increase in A20 expression and decrease in miRNA-125b in DSS-induced murine colitis after administration of bovine MEX supporting the anti-inflammatory activity of MEX in this model of NEC. Notably, increased miRNA-125b expression has been reported in the DSS-induced colitis model, which is suppressed by milk MEVs [84].

\subsection{Milk Exosome Lipidomics and NEC Prevention}

Lipid encapsulation of MEX cargo protects miRNAs and other sensitive components against the harsh conditions in the GI tract [34]. Exosomes are often enriched in cholesterol, sphingomyelin, glycosphingolipids and phosphatidylserine compared to their donor cells. Lipids not only have a structural role in exosomal membranes but also are essential players in exosome formation and release to the extracellular environment and cell signaling [276]. A total of 395 lipids are identified in term and preterm human MEX [277]. Notably, phosphatidylethanolamine (18:1/18:1), phosphatidylcholine (18:0/18:2), phosphatidylcholine (18:1/16:0), phosphatidylserine (18:0/18:1) and phosphatidylserine (18:0/22:6) were enriched in term and preterm human MEX [277]. Pathway analysis indicated that MEX lipids were associated with the ERK/MAPK pathway. LPS treatment increased the expression level of $\mathrm{p}$-ERK, which was reduced after treatment with term and preterm human MEX, suggesting that human MEX lipids may ameliorate NEC phenotypes via the ERK/MAPK signaling [277].

It has recently been demonstrated that HM-specific lipid mediators referred to as 1-Oalkyl-sn-glycerol ether lipids maintain beige adipose tissue (BET) in infants and prevent 
the transdifferentiation of BET into lipid-storing white adipose tissue (WAT) [278]. These aklylglycerols are deficient in cow milk-based infant formula [278].

Various ether lipids have been detected in exosomes [276]. Notably, it has been shown in exosomes derived from PC-3 cells, that the ether lipid precursor hexadecylglycerol stimulates exosome release and changes the protein composition of exosomes [279]. It is thus conceivable that alkylglycerols derived from MGECs may enhance the release of alkylglycerol-loaded MEX that may modify macrophage differentiation $[280,281]$ involved in the transition of BET into WAT [278,282]. MEX may thus function like exosomes from adipose-derived stem cells (ADSC) that attenuate adipose inflammation and obesity through polarizing M2 macrophages and beiging in WAT [282]. MEX-like ADSC-derived exosomes may promote BET, which is important for the maintenance of the body's core temperature of the newborn infant by heat generation due to an uncoupling mitochondrial terminal electron transport chain from ATP generation [283,284].

\subsection{Improvement of Malnutrition-Induced Intestinal Barrier Dysfunction}

Recent evidence in mice fed low protein (1\%) diet showed that malnutrition-induced intestinal villus atrophy and barrier dysfunction could be rescued by oral gavage of bovine MEVs (132 nm; CD9-, CD63-, CD81-positive) [285]. Despite continued low protein diet feeding, MEV/MEX treatment improved intestinal permeability, intestinal architecture and cellular proliferation [285]. These data suggest that MEV administration may be of therapeutic value for the clinical management of malnourished children who are at high risk for morbidity and mortality.

\section{Systemic Bioavailability of Milk Exosomes for Epigenetic Regulation}

Despite an ongoing controversial scientific debate $[7,286]$, accumulating evidence supports the systemic uptake and tissue distribution of MEX and their miRNAs in various animal models $[18,19,161,287]$ and healthy human volunteers $[288,289]$, providing the rationale for the therapeutic use of MEX $[12,17,290-296]$. The suitability of exosomes as delivery vehicles for extracellular RNAs was tested by evaluating the absorption of miRNA148a-3p in hepatic and intestinal cell lines [296]. The appearance of bovine MEX and MEXderived miRNAs in various murine tissues after oral administration of bovine MEX [18,19], the detection of specific bovine MEX miRNAs in the serum of piglets fed on cow milk underline the systemic bioavailability of MEX [287]. Furthermore, the dose-related increase in selected miRNAs in the plasma and blood monocytes of healthy human individuals after consumption of commercial pasteurized cow milk underline the systemic availability of MEX [294,295]. Accumulated evidence confirms the systemic bioavailability of MEX and their gene-regulatory actions $[7,29,30,36,288,289,297]$. The period of development that extends from pre-conception to early infancy is the period of life during which epigenetic DNA imprinting activity is the most active $[298,299]$. The early postnatal period of humans is a critical developmental epigenetic window [300,301]. Physiologically, this critical time period is controlled by signals derived from the human but not from the bovine lactation genome or artificial feeding systems [302,303]. Accumulating evidence identifies MEX as most critical signalosomes of HM that modify postnatal epigenetic regulation [29-31]. MEX-derived miRNA-148a suppresses DNA methylation via targeting DNMT1, which is responsible for maintenance DNA methylation, ensures the fidelity of replication of inherited epigenetic patterns. Notably, DNMT1 has a very distinguishable preference of methylating CpGs on hemimethylated DNA [304,305].

\subsection{Milk Exosomes, Thymic T-Cell Maturation and Atopy Prevention}

Evidence derived from a recent systematic review suggests that feeding HM for short durations or not at all is associated with higher childhood asthma risk [306], whereas breastfeeding offers advantages for the prevention of allergic diseases [307,308]. Maternal atopy is highly associated with food sensitivity among children who were born via Cesarean 
section and were non-exclusively breastfed, whereas no association among children who were vaginally delivered and exclusively breastfed was found [309].

Epigenetic changes and the potential of maternal and postnatal nutrition on the development of allergic disease are in the focus of recent research. Allergic sensitization of mothers modifies their MEX composition. Significantly lower levels of MUC1 were detected on CD63-enriched MEX from sensitized mothers compared with nonsensitized [310]. Notably, mothers whose children developed sensitization had an increased amount of HLA-ABC on their MEX enriched for CD63 [310]. Although several miRNAs (miRNA-4525p, let-7d-3p, miRNA-146b-5p, miRNA-21-5p, miRNA-22-3p, miRNA-375, miRNA-16-5p, miRNA-511-5p, miRNA-26b-5p, let-7f-5p, miRNA-30e-5p, miRNA-374a-5p, miRNA-335$5 p$ ) were differentially expressed between offspring atopic dermatitis (AD) vs. non-AD at 2 years of age, none had an acceptable false discovery rate and their biological significance on the development of $\mathrm{AD}$ was not immediately apparent from functional analysis [311].

Kalliomäki et al. [150] determined the concentrations of TGF- $\beta 1$ and TGF- $\beta 2$ in maternal colostrum and mature milk and hypothesized that TGF- $\beta$ in colostrum may prevent the development of atopic disease during exclusive breastfeeding and promote specific $\operatorname{IgA}$ production in human subjects. Rigotti et al. [151] reported that TGF- $\beta 1$ was significantly less secreted in mature milk of allergic mothers. After 6 months, $46 \%$ infants from allergic mothers, but none from controls, presented AD [151]. Although not yet determined in human MEX, TGF- $\beta$ is a constituent of bovine MEX [147].

Of note, exosomes released by mast cells harbor both active and latent TGF- $\beta 1$ on their surfaces [312]. Remarkably, TGF- $\beta 1$ associated with exosomes has higher signaling stability compared with free TGF- $\beta 1$ and more effectively activates TGF- $\beta 1$ signaling by phosphorylation of SMAD2 [312]. SMAD2/3 are required for the development of tTreg and iTreg cells [313-315]. SMAD2/3 and Treg-specific DNA demethylation has been shown to be important for Treg cell stability $[117-123,125]$. TGF- $\beta$ is another pivotal activator of Treg cell differentiation. In an ovalbumin peptide TCR transgenic adoptive transfer model, TGF- $\beta$-converted transgenic $\mathrm{CD} 4{ }^{+} \mathrm{CD} 25^{+}$suppressor cells proliferated in response to immunization and inhibited antigen-specific naive $\mathrm{CD}^{+} \mathrm{T}$ cell expansion in vivo. In a murine asthma model, co-administration of these TGF- $\beta$-induced suppressor T cells prevented house dust mite-induced allergic pathogenesis in lungs [313]. In accordance, immunosuppressive Treg cells have been induced by intranasal immunization with the live-attenuated pneumococcal vaccine SPY1 via activation of TGF- $\beta 1 / S M A D 2 / 3$ signaling [316]. Thus, deficient exosomal TGF- $\beta$ transfer via HM of atopic mothers as well as missing exosomal TGF- $\beta$ and miRNA-148a signals in artificial formula may impair Treg cell maturation increasing the risk of atopy in infants. Among the multitude of immuneregulatory bioactive compounds in HM, MEX play a key role. Exosomes are natural ancient nanoparticles of life that control critical events in immune regulation $[126,317,318]$.

In fact, MEX belong to the complex signaling system of HM that contributes to the development of the infant's immunity [319]. It has been demonstrated that bovine MEX cross epithelial boarders and reach various murine tissues after oral application $[18,19]$ and may thus reach the thymus supporting MEX miRNA-mediated differentiation of tTreg cells $[124,125]$. Increasing evidence underlines the role of exosomes as important routes of communication within the thymus [320,321] and the induction of Treg cells [322]. It is conceivable that MEX-derived miRNA-148a via targeting DNMT1 as well as MEXmediated transfer of TGF- $\beta$ may augment stable thymic FOXP3 expression and thus tTreg cell development $[130,146]$. The atopy-preventive effect of raw cow milk consumption with abundant transfer of bioavailable bovine MEX [124,125] is abolished by boiling farm milk $[137,141]$. Indeed, boiling and UHT treatment of cow milk dramatically reduces MEX numbers and diminishes their miRNA recovery [139,140]. Notably, the TGF- $\beta 1$ concentration in raw unpasteurized cow milk decreased to $50 \%$ by boiling as well [323]. 


\subsection{Milk Exosomes and Hepatic Metabolism}

The liver is the central organ for glucose and lipid metabolism and is a key frontline immune tissue [324,325]. Substantial accumulation of orally administered bovine MEX in murine liver have been demonstrated [18]. The neonatal crystallizable fragment receptor $(\mathrm{FcRn})$ is responsible for maintaining the long half-life and high levels of the two most abundant circulating proteins, albumin and IgG [326]. Betker et al. [293] proposed that MEX can be taken up as intact particles via transcytosis involving FcRn. In fact, coadministration of bovine IgG with bovine MEX reduced intestinal absorption of fluorescentlabeled bovine MEX [293]. FcRn is significantly expressed in hepatocytes, Kupffer cells, sinusoidal epithelial cells in human liver, apical enterocytes, goblet cells and enterocytes of crypts in the small and large intestine of humans [327]. Organs with the highest FcRn expression are spleen, lymph node, liver and lung [328]. It has recently been shown that exosome-mediated intercellular communication between hepatitis $C$ virus-infected hepatocytes and hepatic stellate cells may be critically involved in pathogenesis of liver fibrosis [329,330].

Over-expression of miRNA-148a in postnatal rat liver reduced the expression of LDL receptor (LDLR), impairing liver cholesterol reverse transport [331], a meaningful mechanism for peripheral cholesterol supply of growing tissues during the breastfeeding period. MEX-mediated transfer of miRNA-148a, which targets hepatic LDLR, may thus direct LDL to peripheral cells required for tissue growth. In a comparable fashion, MEX-derived miRNA-29b via targeting dihydrolipoamide branched chain transacylase (DBT) [332], the core component of branched chain $\alpha$-ketoacid dehydrogenase, may attenuate hepatic catabolism and oxidation of branched-chain amino acids (BCAAs), directing the flux of BCAAs to BCAA-mTORC1-mediated hepatic protein and albumin synthesis [333-335].

\subsection{Milk Exosomes and Neurodevelopment}

Breastfeeding is associated with increased intelligence [4,336,337]. Among 285 participants, each month of exclusive feeding at the breast only was associated with a decreased risk of clinically meaningful executive function (working memory) deficit [338]. Prolonged and exclusive breastfeeding improves children's cognitive development $[339,340]$. As demonstrated by Manca et al. [18], MEX accumulate in the brain of mice after oral administration of bovine MEX. In fact, recent evidence indicates that exosomes are able to cross the blood-brain-barrier [341-344]. The brain undergoes maturation in the early postnatal period. Particularly, the hypothalamic-pituitary axis, an essential regulator of food intake and energy homeostasis, is relatively immature at birth in both rats and mice [345]. During the first 2 weeks of postnatal life, hypothalamic neurons send axonal projections to their target sites and form functional synapses [345]. In early postnatal life, developmental processes are critical for establishing proper neuronal connectivity in the brain requiring the synaptic machinery.

One protein thought to be important in synaptic plasticity is $\alpha$-synuclein ( $\alpha$-syn) [346]. Postnatal expression of $\alpha$-syn is developmentally regulated suggesting that $\alpha$-syn may play a pivotal role in establishing the function of basal ganglia [346]. In the rat, a high level of $\alpha$-syn expression within cell bodies of the substantia nigra pars compacta is observed in the 1st week of postnatal life, which decreases both in intensity and number of immunoreactive cells between postnatal days 7 and 14 [346]. Soluble $\alpha$-syn is an abundant neuronal protein that localizes predominantly to presynaptic terminals [347-350]. Monomeric $\alpha$-syn promotes membrane curvature and assembly of the soluble N-ethyl-maleimide-sensitive factor attachment protein receptor (SNARE) complex, a mediator for vesicle fusion with target membranes [351-353].

Of note, the SNARE protein is also the molecular basis of exocytotic activity for insulin secretion [354]. In addition, $\alpha$-syn contributes to synaptic trafficking, vesicle budding and vesicle recycling, while in the case of dopaminergic neurons, $\alpha$-syn mediates dopamine synthesis, storage and release [355-357]. Furthermore, SNAREs have been proposed 
to facilitate the fusion of multivesicular bodies with the plasma membrane promoting exosome release [358].

Accumulating evidence underlines that hypomethylation of the SNCA promoter increases $\alpha$-syn expression, which is controlled by DNMT1 [359-368]. $\alpha$-syn itself sequesters DNMT1 from the nucleus promoting hypomethylation of SNCA further augmenting $\alpha$-syn expression in a vicious cycle [360]. Remarkably, the depletion of dietary bovine MEX impairs sensorimotor gating and spatial learning in C57BL/6 mice fed an AIN-93G-based, bovine-MEX-deficient diet for up to 20 weeks [369].

\subsection{Milk Exosomes and Potential Impact on Pancreatic $\beta$-Cell Proliferation}

There is recent interest in the role of perinatal nutritional programming of epigenetic processes controlling energy metabolism and body composition maintenance [298-301,370]. Breastfeeding is recommended for the prevention of overweight and type 2 diabetes mellitus (T2DM) [4]. The insulin-secreting pancreatic $\beta$-cells play a central role in glucose homeostasis and metabolic regulation. During the breastfeeding period, pancreatic $\beta$ cells proliferate and extend islet $\beta$-cell mass to provide sufficient capacities for insulin secretion required for the changing demands after weaning and the introduction of solid foods [371-373]. Most $\beta$-cell neogenesis in humans was observed preterm with a burst of $\beta$-cell proliferation, peaking within the first 2 years of life [373]. The $\beta$-cell to $\alpha$-cell ratio doubled neonatally, reflecting increased growth of $\beta$-cells [373]. It is known that the $\beta$-cells ${ }^{\prime}$ proliferative capacity declines postnatally, but the extrinsic cues and intracellular signals that cause this decline remain unknown [374].

Accumulating evidence supports the view that $\beta$-cells are involved in extensive exosome signaling maintaining a metabolic organ cross-talk [375-380]. It has been predicted that MEX derived from HM and pasteurized commercial cow milk may interact with pancreatic $\beta$-cells and promote $\beta$-cells proliferation, a physiological mechanism for postnatal $\beta$-cell mass expansion, but a damaging constellation when MEX-driven $\beta$-cell signaling persists [381,382]. IGF-1/mTORC1 signaling is a key driver of $\beta$-cells proliferation [383-385]. mTORC1 specifically regulates both proliferation and identity maintenance of neonatal $\beta$-cells [385,386]. Milk consumption enhances hepatic IGF-1 secretion and stimulates mTORC1 signaling including $\beta$-cell mTORC1 activation $[6,381,382]$. IGF1 is a DNMT1regulated developmental gene, whose expression is epigenetically enhanced by IGF1 P2 promoter demethylation [66-69]. After weaning, Jafaar et al. [387] observed a switch from increased $\beta$-cell mTORC1 activation toward enhanced 5 -adenosine monophosphateactivated protein kinase (AMPK) signaling. The acquired AMPK-dependent adult $\beta$-cell signature was associated with an increased capacity for glucose-stimulated insulin secretion (GSIS), enhanced $\beta$-cell mitochondrial biogenesis, a shift to oxidative metabolism and functional $\beta$-cell maturation, whereas in T2DM a remarkable reversion of the normal AMPK-dependent adult $\beta$-cell signature to the more neonatal one with increased mTORC1 activation was observed [387]. It has recently been hypothesized that the shift towards higher $\beta$-cell AMPK activity after weaning might be associated with the termination MEX transfer to the infant [382]. During breastfeeding MEX-derived miRNA-148a may suppress $\beta$-cell AMPK activity via targeting the catalytic subunit $\alpha 1$ of AMPK (PRKAA1) as well as the AMPK regulatory subunit $\gamma 2$ (PRKAG2) [382,388]. Further important target genes of miRNA-148a are MAFB (V-MAF musculoaponeurotic fibrosarcoma oncogene family, protein $\mathrm{B}$ ), which is involved in $\beta$-cell differentiation, ESRRG (estrogen-related receptor- $\gamma$ ) and PPARGC1A (peroxisome proliferator-activated receptor- $\gamma$, co-activator $1 \alpha$ ), which regulate mitochondrial function and oxidative metabolism [382]. Furthermore, loss of DNMT1, a key target of miRNA-148a, results in the conversion of pancreatic islet $\alpha$-cells into $\beta$-cells [389].

Taken together, translational evidence links MEX to epigenetic regulation of $\beta$-cell proliferation and $\beta$-cell mass expansion, whereas the decline of MEX miRNA-148a signaling during the weaning period may explain the switch towards functional $\beta$-cell maturation [382]. Notably, increased plasma levels of miRNA-148a have been found in patients 
with T2DM exhibiting correlations with pathological oral glucose tolerance test, glycated hemoglobin $(\mathrm{HbA1c})$, insulinemia and increased homeostasis model assessment for insulin resistance (HOMA-IR) [390].

Recently, aberrant levels of miRNAs have been detected in MEX of mothers with type 1 diabetes mellitus (T1DM) [391]. Nine MEX miRNAs were found differentially expressed in mothers with T1DM compared to healthy mothers. The highly up-regulated miRNAs, hsa-miR-4497 and hsa-miR-3178, increased LPS-induced expression and secretion of TNF- $\alpha$ in human monocytes. The up-regulated miRNA target genes were significantly enriched for longevity-regulating pathways and FOXO signaling [391].

RIP140, the key regulator of metabolic balance, plays also an important role in $\beta$-cell homeostasis and insulin secretion [392]. Over-expression of RIP140 promoted apoptosis but inhibited cell viability in MIN6 cells, and basal insulin secretion and GSIS levels were altered following treatment with glucose and palmitic acid. In addition, oxidative stress was elevated, phosphorylated extracellular signal-regulated kinases $1 / 2$ and uncoupling protein 2 (UCP2) messenger RNA (mRNA) abundance were increased, B-cell lymphoma-2 protein levels were decreased, and PPAR $\gamma$ co-activator $1 \alpha$, phosphoenolpyruvate carboxykinase and pancreatic and duodenal homeobox-1 mRNA levels were down-regulated. Furthermore, glucolipotoxicity-induced damage was reversed when RIP140 expression was down-regulated by small interfering RNA (siRNA) [392]. Thus, MEX miRNA-30b via suppressing RIP140 may enhance $\beta$-cell function and insulin secretion, which is important for mTORC1-dependent postnatal growth.

\subsection{Milk Exosomes and Their Potential Impact on Beige/Brown Adipogenesis}

Breastfeeding is inversely associated with a risk of early obesity in children aged 2 to 6 years. Moreover, there is a dose-response effect between the duration of breastfeeding and reduced risk of early childhood obesity [393-396]. Adipose tissue undergoes profound compositional changes in early life, of which an increased understanding could offer potential interventions to retain brown adipose tissue (BAT) in later life [397]. Like HM-derivedalkylglycerols [278], MEX may also function as signalosomes modifying the homeostasis of BET, BAT and WAT. From a teleological point of view, MEX should promote both BET/BAT and WAT to maintain adequate thermogenesis and storage of energy reservoirs.

Dominant miRNAs of HM, such as miRNA-30b, miRNA-155 and miRNA-148a, are related to adipose tissue development. Recently, Villatoro et al. [398] demonstrated that canine colostrum exosomes (CCE) modified the proliferation and secretory profiles in canine mesenchymal stem cells derived from bone marrow (cBM-MSCs) and adipose tissue (cAd-MSCs). An increase in cAd-MSCs proliferation for 12 days in the presence of CCE, whereas this effect was not observed in cBM-MSCs [397]. Kupsco et al. [40] evaluated MEX miRNA expression in relation to maternal BMI (in $\mathrm{kg} / \mathrm{m}^{2}$ ). Of 419 miRNAs evaluated, 374 were negatively associated with BMI, whereas miRNA-4769-5p was weakly, but significantly, positively associated with BMI. The top four miRNAs most significantly negatively associated with BMI were miRNA-128-3p, miR-130a-3p, miRNA-574-3p and miRNA-6881-5p [40]. Recently, Shah et al. [399] investigated the impact of maternal overweight/obesity on selected HM MEX-derived miRNAs involved in adipogenesis and glucose metabolism to elucidate their relationship with measures of infant body composition in the first 6 months of life. Remarkably, the abundance of miRNA-148a and miRNA-30b in the overweight/obesity group was lower by $30 \%$ and $42 \%$, respectively, compared with the control group at 1 month. miRNA-148a was negatively associated with infant weight, fat mass and fat free mass, while miRNA-30b was positively associated with infant weight, percent body fat content and fat mass at 1 month.

There is translational evidence miRNA-148a and miRNA-30b control the expression of uncoupling protein 1 (UCP1) in BET mitochondria that are functionally thermogenic (Figure 4) [283,400,401]. It has been shown in murine adipose tissue that UCP1 expression is increased by $U C P 1$ enhancer methylation [402,403]. A previous study revealed that RIP140 and DNMT1 are both involved in the methylation of the enhancer and promoter of 
the murine UCP1 gene [404]. In mouse adipocytes, RIP140 has been shown to elicit DNA methylation of the UCP1 enhancer and promoter through binding to DNMT1, leading to transcriptional repression [404]. Tissue-dependent regulation of DNMT1 activity may be involved in the variation of DNA methylation of the UCP1 enhancer and promoter [404]. MEX miRNA-148a-mediated suppression of DNMT1 may thus increase the expression of UCP1 enhancing thermogenesis and conversion of white to beige/brown adipocytes.

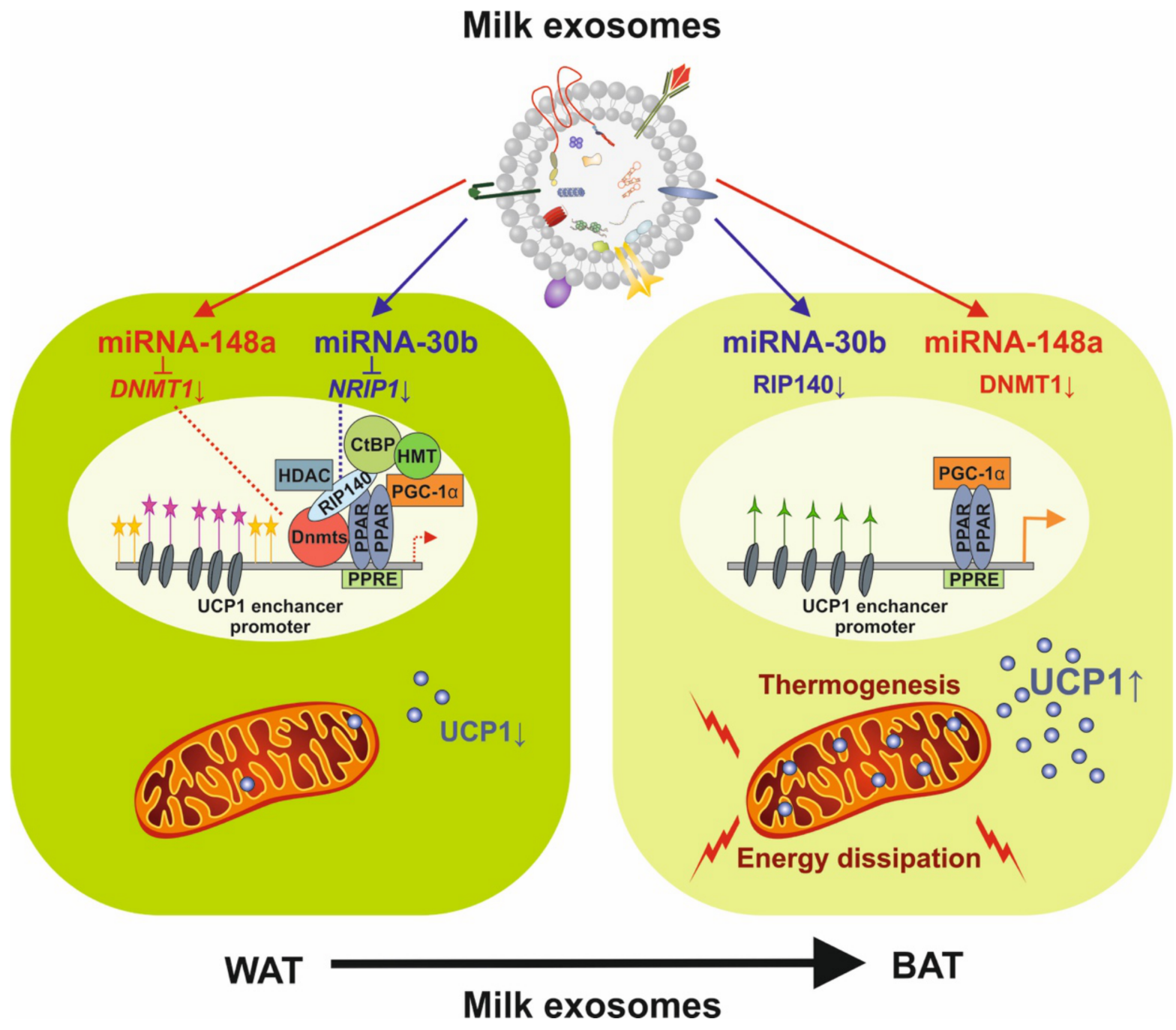

Figure 4. Potential impact of milk exosome-derived miRNA-148a and miRNA-30b on the expression of uncoupling protein 1 (UCP1). miRNA-148a inhibits DNA methyltransferase 1 (DNMT1) and miRNA-30b directly targets the mRNA of NRIP1 encoding receptor-interacting protein 140 (RIP140), activating the enhancer/promoter of UCP1 and increasing UCP1 expression, which drives thermogenesis and the conversion of white adipose tissue (WAT) into brown adipose tissue (BAT).

Xi et al. [405] reported that levels of miRNA-30b, let-7a and miRNA-378 in colostrum were negatively correlated with maternal pre-pregnancy BMI. Intriguingly, miRNA-30b/c concentrations are greatly increased during adipocyte differentiation and are stimulated by cold exposure or the $\beta$-adrenergic receptor activator. Over-expression and knockdown of miRNA-30b and miRNA-30c induced and suppressed the expression of thermogenic genes such as UCP1 and death-inducing DFFA-like effector A (CIDEA) in brown adipocytes [244], respectively. Of note, the promoter activity of the lipid droplet protein CIDEA is repressed by RIP140 and induced by PGC- $1 \alpha$ mediated through the binding of estrogen-related receptor- $\alpha(E R R \alpha)$ and nuclear respiratory factor 1 (NRF-1) to their cognate binding sites [406]. RIP140 interacts directly with PGC- $1 \alpha$ and suppresses its activity [406]. It is widely accepted that PGC- $1 \alpha$ acts as a mediator of mitochondrial biogenesis $[407,408]$. 
Forced expression of miRNA-30b/c also significantly increased thermogenic gene expression and mitochondrial respiration in primary adipocytes derived from subcutaneous WAT, demonstrating a promoting effect of miRNAs on the development of BET. In addition, knockdown of miRNA-30b/c repressed UCP1 expression in BAT in vivo. Notably, miRNA-30b/c targets the $3^{\prime}$ UTR region of the mRNA of RIP140 (NRIP1) [244]. Thus, overexpression of miRNA-30b/c significantly reduced RIP140 expression [244]. Mice devoid of RIP140 are lean, show resistance to high-fat diet-induced obesity and hepatic steatosis and have increased oxygen consumption. Although the process of adipogenesis is unaffected, expression of certain lipogenic enzymes is reduced. In contrast, genes involved in energy dissipation and mitochondrial uncoupling, including UCP1, are markedly increased [409]. Consistent with RIP140 as a target of miRNA-30b/c in regulating thermogenic gene expression, over-expression of RIP140 greatly suppressed the promoting effect of miRNA-30b/c on the expression of UCP1 and CIDEA in brown adipocytes [244]. RIP140 is a co-repressor for nuclear receptors that suppresses transcription from a broad program of metabolic genes and thereby controls energy homoeostasis in vivo [410,411]. Thus, miRNA-30b/c are key regulators of thermogenesis and uncover a new mechanism underlying the regulation of BAT function and the development of BET [244].

In contrast, over-expression of miRNA-155 in mice causes a reduction in BAT mass and impairment of BAT function [412]. miRNA-155 and its target, the adipogenic transcription factor CCAAT/enhancer-binding protein $\beta$ (CEBP $\beta$ ), form a feedback loop integrating hormonal signals that regulate proliferation or differentiation [413].

Obviously, the appropriate balance of miRNA-148a, miRNA-30b/c and miRNA-155 controls the development of BET and BAT. MEX-derived miRNAs may contribute to the proper adjustment of miRNA-mediated adipogenic signaling. It is thus of critical concern that compared to HM, critical thermogenesis-regulating miRNAs are missing in infant formulas $[42,164]$.

\subsection{Milk Exosomes and Their Potential Impact on White Adipogenesis}

There is increasing interest in the role of miRNAs in the regulation of BAT and BET as well as WAT [414]. However, studies on the impact of MEX on mesenchymal stem cell differentiation in humans and their role in the development of WAT, BET and BAT during the breastfeeding period are still missing. There is convincing evidence that miRNA148a promotes the differentiation of pre-adipocytes to adipocytes [415-420]. Analysis of the upstream region of MIR148A locus identified a $3 \mathrm{~kb}$ region containing a functional cAMP-response element-binding protein (CREB) required for miRNA-148a expression in Ad-MSCs. The results suggest that miRNA-148a is a biomarker of obesity in human subjects and mouse models, which represents a CREB-modulated miRNA that acts to repress WNT1, thereby promoting adipocyte differentiation [415]. Furthermore, a potential X-box-binding protein 1 (XBP1) response element was found in the promoter region of MIR148A. An miRNA-148a mimic significantly restored adipogenic potential in XBP1deficient 3T3-L1 cells providing evidence that XBP1s can suppress WNT10b by directly inducing miRNA-148a [417].

Type I procollagen mRNA expression is down-regulated during adipocyte differentiation [421]. Type 1 collagen inhibits adipogenic differentiation via Yes-associated protein (YAP) activation in vitro [422].

miRNA-148a-3p mimics have been shown to inhibit the expression of type I collagen in a model of alcoholic liver fibrosis [423], which may promote adipogenesis. In contrast, Reif et al. [27] demonstrated that HM-derived MEX significantly induced collagen type 1 expression in normal colon cells (CCD841).

It is generally accepted that CCAAT enhancer-binding protein- $\alpha(\mathrm{C} / \mathrm{EBP} \alpha)$ and PPAR $\gamma$ are the key factors in modulating adipocyte differentiation and are the crucial genes for pre-adipocytes [412]. Recent evidence indicates that peroxisome proliferator-activated receptor-co-activator 1- $\beta$ (PGC-1 $\beta$ ) encoded on the PGC1B gene modulates the expression of key genes involved in adipogenesis during pre-adipocyte differentiation [424]. PGC-1 $\beta$ 
interference caused a significant decrease in lipid accumulation in chicken adipocytes with decreasing mRNA and protein abundances of PPAR $\gamma$ and sterol-regulatory element binding protein 1c (SREBP-1c), fatty acid synthase (FAS) and adipocyte type fatty acid binding protein (A-FABP) [424]. PGC-1 $\beta$ is restricted to the maintenance of basal mitochondrial function [408].

Kamei et al. [425] showed that PGC-1 $\beta$ functioned as a ligand for orphan ERRs. Transgenic mice over-expressing PGC-1 $\beta$ exhibited increased expression of medium-chain acyl-CoA dehydrogenase, an ERR target and a pivotal enzyme in mitochondrial $\beta$-oxidation in skeletal muscle. As a result, transgenic mice were hyperphagic, showed elevated energy expenditure and were resistant to obesity induced by a high-fat diet or by genetic abnormality. PGC- $1 \beta$ is an ERR protein ligand, whose expression induces a high-energy expenditure and antagonizes obesity. PGC- $1 \beta$ thus contributes to the control of energy balance $[408,425]$. Importantly, PPARGC1B is a direct target of miRNA-148a-3p. PGC-1 $\beta$ mRNAs were present at very low levels in 3T3-L1 pre-adipocytes and were markedly induced during adipocyte differentiation [425].

Over-expression of PGC-1 $\beta$ up-regulated the expressions of adipogenic and mitochondrial biosynthetic marker genes and promoted triacylglycerol accumulation during 3T3-L1 adipocyte differentiation. These observations suggest that PGC-1 $\beta$ modulates the expression of mitochondrial function and adipogenesis-related genes and affects white pre-adipocyte differentiation [426]. MEX-mediated transfer of miRNA148a via suppressing PGC- $1 \beta$ may thus interfere with the metabolic control of mitochondrial biogenesis and energy expenditure through the PGC-1 family regulatory network [427].

The miRNA-148a target UCP3 is abundant in skeletal muscle and is involved in the regulation of postprandial thermogenesis [428]. The expression of UCP3 directly correlates to UCP1 abundance in BAT [429]. UCP3 abundance directly correlates with the degree of fatty acid $\beta$-oxidation in cell metabolism [430].

Cholecystokinin (CCK), which is secreted from endocrine IECs when the duodenum is filled with food, is a hypothalamic hormone that controls food intake [431]. CCK binds and signals via CCK1 receptor (CCK1R) and CCK2R. Notably, CCK2R knock out mice develop obesity associated with hyperphagia [432]. CCK2R deletion was associated with increased body weight and hypothalamic neuropeptide Y (NPY) content, which explains the increased food intake in CCK2R knockout mice [433]. Notably, the gene expressing CCK2R (CCKBR) is a direct target gene of miRNA-148a [434]. In addition, miRNA-148a attenuates the expression of LDLR and hepatic expression of ATP-binding cassette, subfamily A, member 1 (ABCA1) [435]. ABCA1 is a major regulator of plasma high density-lipoprotein (HDL) cholesterol responsible for the removal of excess cholesterol from peripheral cells and tissues [436,437]. Moreover, RIP140 negatively regulates the expression of ABCA1 by suppressing the expression and activity of liver $X$ receptor (LXR) [438].

Apparently, MEX-derived miRNAs, especially the most abundant miRNA-148a of HM and MEX, have a significant impact on the regulation and programming of adipogenesis, energy, lipid and lipoprotein metabolism during the physiological period of breastfeeding.

\subsection{Milk Exosomes and Bone Homeostasis}

Mesenchymal stem cells (MSC) can differentiate into cells of the mesodermal lineage, such as adipocytes and osteocytes [439]. Postnatal bone development is characterized by substantial longitudinal bone growth and changes in skeletal size and shape. Bone is in a dynamic process of continuous remodeling, which helps to regulate calcium homeostasis, repair micro-damage to bones from everyday stress, and to shape the skeleton during growth [440]. During early childhood, both bone modelling (the formation and shaping of bone) and bone remodelling - the replacement or renewal of old bone-occur. The predominant process in childhood is bone modelling, while in adulthood, bone remodeling predominates [441]. Breastfeeding was beneficially associated with hip and total body areal bone mineral density (BMD) and total, cortical and trabecular volumetric BMD, as well as cortical thickness, porosity, trabecular number, separation and bone volume fraction at 
radius and/or tibia at 25 years of age in participants born prematurely, but there were no associations in those born at term [442]. During bone growth, bone-forming osteoblasts and bone-resorbing osteoclasts interact with blood vessel-forming endothelial cells [443].

There is compelling evidence that exosomes and their miRNA cargo play a crucial role in bone remodeling [444-447]. Notably, miRNA-148a-3p promotes adipocyte but inhibits osteoblast differentiation by targeting lysine-specific demethylase $6 \mathrm{~b}$ [418]. MAF family members appear to play important roles in the regulation of MSC differentiation [448]. Nishikawa et al. [449] demonstrated that decreased expression of MAF in mouse MSCs, which regulated MSC bifurcation into osteoblasts and adipocytes, impaired osteogenesis. In fact, delayed bone formation has been observed in perinatal $\mathrm{Maf}^{-1-}$ mice [450]. Over-expression of miRNA-148a in CD14 ${ }^{+}$PBMCs promoted osteoclastogenesis, whereas inhibition of miRNA-148a attenuated osteoclastogenesis. MAFB is a transcription factor negatively regulating RANKL-induced osteoclastogenesis. miRNA-148a directly targets MAF and MAFB mRNA by binding to the $3^{\prime} \mathrm{UTR}$ and repressed MAFB protein expression [450].

There is recent interest in the impact of MEX and their miRNAs in osteogenesis and bone homeostasis. Intriguingly, Oliveira et al. [451] demonstrated that bovine MEX promoted osteoclast differentiation associated with an increased expression of c-Fos, which is important for the differentiation of pre-osteoclasts to osteoclasts [452]. The exposure of human MSCs to bovine MEX during 21 days resulted in less mineralization but higher cell proliferation and enhanced the expression of genes characteristic for immature osteoblasts [453]. Oral delivery of bovine MEX to female DBA1/J mice for 7 weeks increased osteoclast numbers but did not lead to more bone resorption [454]. In a model of bone loss induced by ovariectomy, increased osteoclast numbers in the femur were lowered by treatment with bovine MEX [454]. Yun et al. [455] recently reported that bovine colostrumderived exosomes reduced osteoclast differentiation. The investigators induced osteoporosis in a mouse model using glucocorticoid pellets after orally administering colostrum exosomes for 2 months. Interestingly, the bone mineral density of colostrum exosome-fed mouse groups was significantly improved compared with the glucocorticoid-induced osteoporosis group without exosome treatment [455].

Recently, a potentially novel role for RIP140 in osteoclast differentiation, activity and bone turnover was reported [456]. RIP140 plays a physiological role in osteoclast precursors by regulating osteoclast differentiation through the formation of a suppressive transcription regulatory complex with testicular receptor 4 (TR4). RIP140 functions primarily by inhibiting osteoclast differentiation through forming a transcription-suppressor complex with TR4 to repress osteoclastogenic genes. These data reveal that monocyte/macrophage RIP140/TR4 complexes may serve as a critical transcription regulatory complex maintaining homeostasis of osteoclast differentiation, activity and coupling with osteoblast formation. MEX miRNA-30b mediated suppression of RIP140 may thus modify the balance of osteoclastogenesis towards osteoblastogenesis, which may be a meaningful mechanism for bone growth and bone modeling of the immobile newborn infant because bone formation of osteocytes physiologically requires mechanical stimuli [457].

Cortical bone development includes both pore closure and accumulation of high density bone. These processes require suppression of GP130-STAT3 signalling in osteocytes [458], which may be supported by MEX miRNA-148a-mediated suppression of GP130.

Taken together, translational evidence indicates that MEX under physiological conditions promote osteoclasts formation compared to osteoblasts during the postnatal period.

The potential impact of MEX miRNA-148a on adipocyte differentiation in relation to osteogenesis may secure energy reserves for the newborn. MEX-mediated promotion of osteoclast activity is of pivotal importance for the growing bone. In fact, osteoclasts not only resorb bone, but they also secrete anabolic signals that induce MSCs and osteoblasts to initiate osteogenesis in resorption lacuna (remodeling) or another non-resorbed site (modeling) [459]. 
Table 2 presents selected key targets of miRNA-148a, the predominant miRNA of MEX

Table 2. Selected targets of MEX-derived miRNA-148a-3p and functional outcomes.

\begin{tabular}{|c|c|}
\hline $\begin{array}{l}\text { miRNA-148a 3p } \\
\text { Target Genes }\end{array}$ & Potential Functional Outcomes During Breastfeeding \\
\hline PRKAA1 & $\begin{array}{l}\text { Inhibition of AMPK; suppression of pancreatic } \beta \text {-cell activation; } \\
\text { increased IEC-and } \beta \text {-cell mTORC1 activity with IEC and } \beta \text {-cell proliferation }\end{array}$ \\
\hline PRKAG2 & $\begin{array}{l}\text { Inhibition of AMPK; suppression of } \beta \text {-cell activation; } \\
\text { increased IEC and } \beta \text {-cell mTORC1 activity with IEC- and } \beta \text { cell proliferation }\end{array}$ \\
\hline PPARGC1B & Inhibition of PCG-1 $\beta$; Reduced mitochondrial function \\
\hline UCP3 & Reduced fatty acid $\beta$-oxidation and energy expenditure \\
\hline CCK2R & Reduced satiety signals increasing milk/food intake \\
\hline$M A F B$ & Increased osteoclastogenesis \\
\hline$L D L R$ & Reduced hepatic LDL cholesterol uptake \\
\hline$A B C A 1$ & Reduced HDL-mediated reverse cholesterol transport \\
\hline COL1A1 & Reduced collagen I synthesis \\
\hline IL6ST (GP130) & $\begin{array}{l}\text { Reduced expression of GP130 resulting in attenuated IL-6 signaling, } \\
\text { increased cortical bone maturation }\end{array}$ \\
\hline$I K B K A$ & Inhibition of IкB kinase $\alpha$ and NF-кB signaling, suppression of inflammation \\
\hline$I K B K B$ & Inhibition of I $\mathrm{\kappa B}$ kinase $\beta$ and NF- $\kappa \mathrm{B}$ signaling, suppression of inflammation \\
\hline$C A M K 2 A$ & $\begin{array}{l}\text { Inhibition of calcium/calmodulin-dependent protein kinase II } \alpha \text { and downstream } \\
\text { TLR4 signaling }\end{array}$ \\
\hline DNMT1 & $\begin{array}{c}\text { Inhibition of DNA methyltransferase } 1 \text { increasing epigenetic expression of } \\
\text { developmental genes (INS, IGF1; SNCA, FOXP3) and suppression of RIP140 } \\
\text { expression and RIP140-dependent nuclear receptors and transcription factors such } \\
\text { as PGC-1 } \alpha\end{array}$ \\
\hline
\end{tabular}

\section{Milk Processing and Exosome Bioavailability}

There is recent interest to use MEX and their miRNA cargo for the treatment and prevention of NEC [230] and to supplement MEX-deficient artificial formula [460]. The recovery of MEX after heat treatment depends on temperature and heat exposure time. Whereas UHT $\left(135^{\circ} \mathrm{C},>1 \mathrm{~s}\right)$ and boiling $\left(100{ }^{\circ} \mathrm{C}\right)$ of commercial cow milk destroys MEVs and MEX and their miRNA cargo [139,140], pasteurization $\left(72-78{ }^{\circ} \mathrm{C},>15 \mathrm{~s}\right)$ of commercial cow milk did not affect MEV numbers and preserved nearly $25-40 \%$ of milk's total small RNAs [139]. HoP of $\mathrm{HM}\left(62.5^{\circ} \mathrm{C}, 30 \mathrm{~min}\right)$ resulted in a significant decrease in MEX [22]. High pressure processing (HPP) of HM caused a statistically insignificant decrease in the number of miRNA reads compared to unprocessed material, whereas HoP led to a 302-fold decrease in exosomes not leaving enough reads for miRNA analysis [22]. It has been suggested that UV-C irradiation (UVC) is potentially a gentler method than HoP for pasteurizing donor milk for preterm infants preserving HM's bioactive factors [461]. However, the effects of UV-C irradiation on MEX structure and bioavailbilty have not yet been studied. Other recent preservation methods of HM focus on freezing, lyophilization and freeze-drying [462-465]. These studies as well do not yet provide data on MEX and MEX miRNA bioavailability. Notably, lyophilization of exosomes without the cryoprotectant trehalose results in exosome aggregation, while the addition of trehalose prevents aggregation during lyophilization [466,467].

\section{Conclusions}

Human milk is a complex biological liquid comparable to blood that contains cells and multifaceted biological compounds including carrier systems, which provide nutrition to infants and help to develop their immune and metabolic systems $[319,468]$. The presence of secretory immunoglobulins (IgA), leukocytes, stem cells, lysozyme, lactoferrin, etc., in HM and their role in imparting passive immunity to infants, as well as modulating development 
of an infant's immune system, is well-established. There is compelling evidence that MEX, a special subclass of HM's large spectrum of MEVs, represent critical signalosomes that transfer regulatory RNAs, signaling proteins and mediator lipids that orchestrate epigenetic programming of the immune system and metabolism during a critical postnatal window of mammalian development [29,30,33,35,124,125].

Although the majority of studies presented here focused on biological information provided by MEX and their miRNAs, especially miRNA-148a, the whole spectrum of MEVs and their multiple RNAs contributes to milk's functionality and complex signaling that requires further studies to appreciate the physiology and signaling capacity of milk, the masterpiece of mammalian evolution.

Obviously, MEVs and MEX relay biological "big data" originating from the highly conserved lactation genome from the mother to her infant. In a highly responsive manner, MEX quantities and composition vary depending on the time of delivery (preterm/term), the course of lactation (colostrum, mature milk), environmental factors (maternal obesity, allergic sensitization) and hormonal factors (oxytocin, prolactin and melatonin). MEX stabilize IEC proliferation maturation and ISC activity and improve intestinal barrier function, including the formation of TJs, the mucus barrier and anti-microbial barrier. In addition, MEX and their miRNA cargo attenuate local intestinal inflammation, underlining their most favorable impact for the prevention and treatment of NEC. Apart from the beneficial effects of MEX on the intestine, we are beginning to appreciate their potential systemic interactions with the thymus, brain, liver, pancreatic $\beta$-cells, adipose tissues and bones during the restricted life period of breastfeeding.

Starting out with an only rudimentary scientific knowledge of milk, milk's complex biology and functionality was misconceived by pediatrics of the 1920s and has been erroneously over-simplified as "just food", allowing the large-scale introduction of unsweetened evaporated milk for the preparation of infant feeding formulas [469]. The artificial replacement of breastfeeding was promoted by rigorous marketing of formula as "the better milk for babies" [470]. After years of laborious adjustments of formula protein overload [471-473] with adipogenic mTORC1-activating amino acids [474,475], we are now facing another formula deficit, i.e., the absence of MEVs, MEX and MEX-delivered miRNAs [42,164]. The highly dynamic and complex biosynthesis and signaling of MEX and their miRNAs, including their incompletely understood lncRNAs and circRNAs, make a "static" formulation with selected miRNAs a bold venture. We should appreciate all signaling effectors of HM developed by millions of years of evolution of mammalian lactation [476]. The enrichment of MEX in all mammals and their highly conserved nucleotide sequence homology of the major MEX miRNAs underlines that MEX play a prominent evolutionary role during a most critical epigenetic and metabolic window of mammalian development. The potential impact of MEX and their cargo on global epigenetic and metabolic regulators such as DNMT1 and RIP140 exemplifies the complexity of this evolutionary system which is impossible to copy. It is incomprehensible that we expose our offspring to insufficiently controlled artificial feeding systems that we have not yet understood in detail.

The only secure way to guarantee optimized epigenetic and metabolic programming during the postnatal period is a strict return to the belief into the confidence and functionality of our own lactation genome. A normal BMI during pregnancy and avoidance of unnecessary Casarean sections and formula feeding but sufficient breastfeeding/programming may offer a great chance for the prevention of noncommunicable diseases of civilization, which appear to be communicable by a better understanding of HM's postnatal imprinting mechansisms. For mothers unable to provide adequate breastfeeding, human donor milk may be a substitute but may already lead to deviations in epigenetic programming, as recently shown in a murine model [31].

At present, the processing and conservation methods of human donor milk have not been sufficiently controlled for the bioavailability of MEX and their complex cargo. The presented epigenetic impact of MEX miRNA signaling among other complex milk- 
derived signals allows the conclusion that babies are not simply "breast-fed" but are most importanly "programmed by the breast", the charateristic gland defining mammals.

In 1913, Sir Truby King, a prominent child health reformer and proponent of breastfeeding, stated that breastfeeding is not only the best for the mother and her baby, but is a baby's birthright [477]. With our contemporary knowledge of milk's sophisticated and still mysterious molecular biology, we recommend that breastfeeding is best for infant health and development [478], offering a great chance for prevention of diseases of civilization [4].

Author Contributions: Conceptualization B.C.M., who performed translational research, collected data and prepared the original draft of the manuscript. W.S. reviewed the manuscript with special attention to gastrointestinal physiology and pathophysiology. S.M.J. reviewed and improved the manuscript with special focus on immunological aspects and allergy prevention. R.W. checked pathways of inflammatory signaling and liver metabolisn and improved the visualization of the data. G.S. supervised the publication project and controlled data of lipidomics, miRNA and exosome biology. All authors have read and agreed to the published version of the manuscript.

Funding: This research received no external funding.

Institutional Review Board Statement: Not applicable.

Informed Consent Statement: Not applicable.

Data Availability Statement: All data are derived from the PubMed database and are in agreement with MDPI Research Data Policies.

Acknowledgments: The authors appreciate continued and critical scientific discussions on milk's biology and pathology with Harald zur Hausen and Claus Leitzmann. We thank Sabine Weiskirchen for her excellent art work and Helena Ord for language improvements of the manuscript.

Conflicts of Interest: The authors declare no conflict of interest.

\section{List of Abbreviations (in Alphabetical Order)}

$\begin{array}{ll}\text { AD } & \text { atopic dermatitis } \\ \text { AMPK } & \text { adenosine monophosphate-activated protein kinase } \\ \alpha \text {-syn } & \alpha \text {-synuclein } \\ \text { BAT } & \text { brown adipose tissue } \\ \text { BCAA } & \text { branched-chain amino acid } \\ \text { BCKD } & \text { branched-chain } \alpha \text {-ketoacid dehydrogenase } \\ \text { BET } & \text { beige adipose tissue } \\ \text { BLG } & \beta \text {-lactoglobulin } \\ \text { BMI } & \text { body mass index } \\ \text { BMMF } & \text { bovine meat and milk factor } \\ \text { CAV3 } & \text { caveolin 3 } \\ \text { CaMKII } \alpha & \text { calcium/calmodulin-dependent protein kinase II } \alpha \\ \text { CARMA1 } & \text { CARD-containing MAGUK protein 1 } \\ \text { CCK } & \text { cholecystokinin } \\ \text { CCKR } & \text { cholecystokinin receptor } \\ \text { CCR } & \text { chemokine, CC motif, receptor } \\ \text { CDX2 } & \text { caudal-type homeobox transcription factor } 2 \\ \text { CEBP } & \text { CCAAT/enhancer-binding protein } \\ \text { CIDEA } & \text { death-inducing DFFA-like effector A } \\ \text { circRNA } & \text { circular RNA } \\ \text { CLDN1 } & \text { claudin 1 } \\ \text { CMA } & \text { cow milk allergy } \\ \text { CRC } & \text { colorectal cancer } \\ \text { CYR61 } & \text { cystein-rich protein 61 } \\ \text { DBT } & \text { dihydrolipoamide branched-chain transacylase } \\ \text { DC } & \text { dendritic cell } \\ \text { DMBT1 } & \text { deleted in malignant brain tumors 1 } \\ \text { DNMT1 } & \text { DNA methyltransferase 1 } \\ \text { DON } & \text { deoxynivalenol } \\ \text { DSS } & \text { dextran sodium sulfate } \\ \text { ERR } \alpha & \text { estrogen-related receptor- } \alpha \\ \text { ER } & \text { endoplasmic reticulum } \\ \text { EV } & \text { neonatal crystallizable fragment receptor } \\ \text { FCRn } & \end{array}$




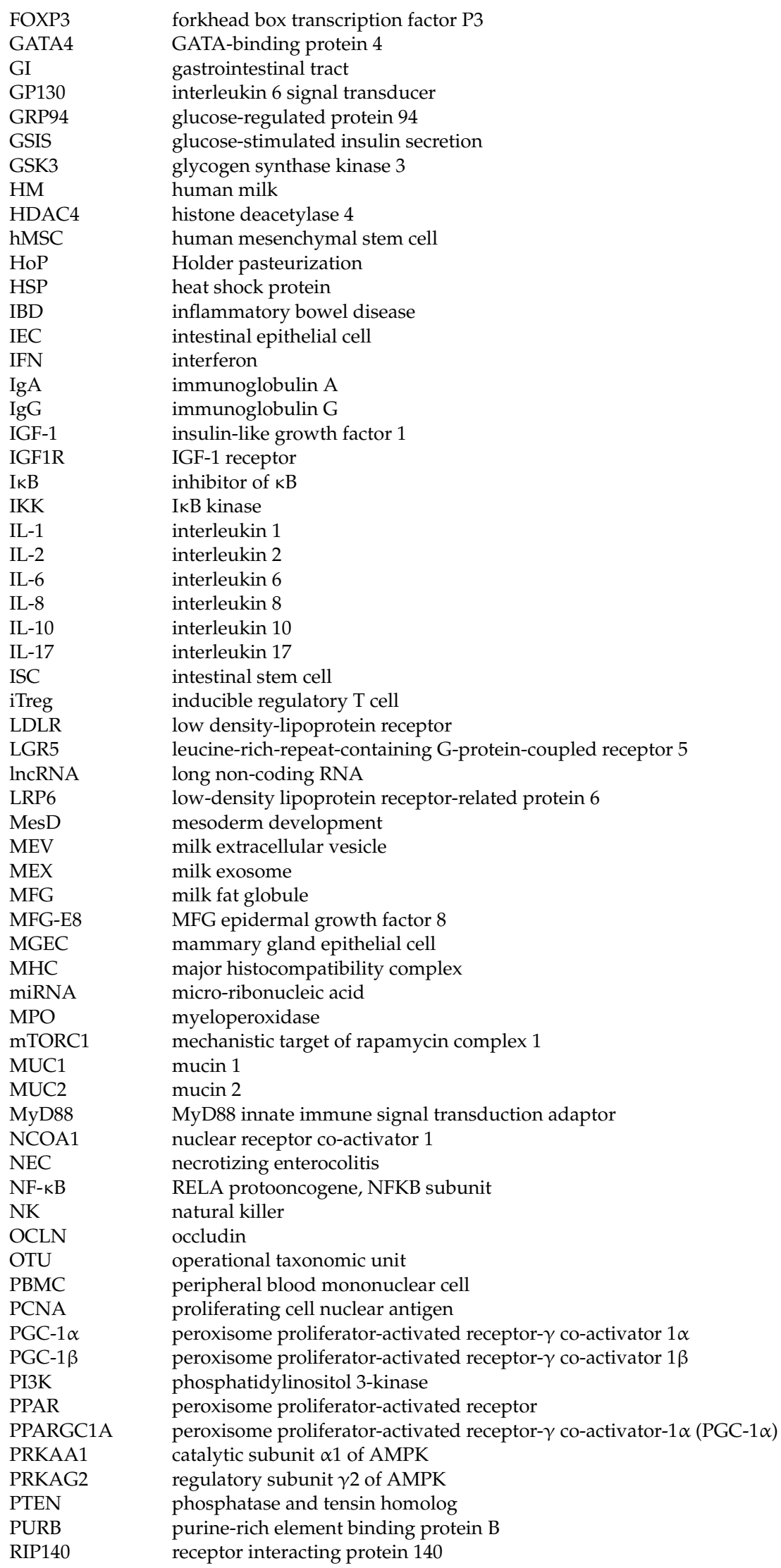




$\begin{array}{ll}\text { RegIII } \gamma & \text { regenerating islet-derived } 3 \gamma \\ \text { ROR } & \text { RAR-related orphan receptor } \\ \text { SIRT1 } & \text { sirtuin } 1 \\ \text { SNARE } & \text { soluble N-ethylmaleimide-sensitive factor attachment protein receptor } \\ \text { SOCS1 } & \text { signal transducer and activator of transcription 1 } \\ \text { SNCA } & \alpha \text {-synuclein } \\ \text { STAT } & \text { signal transducer and activator of transcription } \\ \text { TCR } & \text { T cell receptor } \\ \text { TGF } \beta & \text { transforming growth factor- } \beta \\ \text { TJ } & \text { tight junction } \\ \text { TLR } & \text { toll-like receptor } \\ \text { TNF } \alpha & \text { tumor necrosis factor- } \alpha \\ \text { TNFAIP3 } & \text { TNF } \alpha \text {-induced protein } 3 \\ \text { TFF3 } & \text { trefoil factor 3 } \\ \text { T2DM } & \text { type 2 diabetes mellitus } \\ \text { Treg } & \text { FOXP3+ regulatory T cell } \\ \text { TSDR } & \text { Treg-specific demethylated region } \\ \text { TSG101 } & \text { tumor susceptibility gene 101 } \\ \text { UCP1 } & \text { uncoupling protein 1 } \\ \text { UCP2 } & \text { uncoupling protein 2 } \\ \text { UCP3 } & \text { uncoupling protein 3 } \\ \text { UHT } & \text { ultraheat-treated } \\ 3^{\prime} \text { UTR } & 3^{\prime} \text {-untranslated region } \\ \text { VEGF } & \text { vascular endothelial growth factor } \\ \text { WAT } & \text { white adipose tissue } \\ \text { WNT } & \text { wingless } \\ \text { ZO-1 } & \text { zonula occludens 1 } \\ & \end{array}$

\section{References}

1. Renz, H.; Brandtzaeg, P.; Hornef, M. The impact of perinatal immune development on mucosal homeostasis and chronic inflammation. Nat. Rev. Immunol. 2011, 12, 9-23. [CrossRef] [PubMed]

2. Zonneveld, M.I.; van Herwijnen, M.J.C.; Fernandez-Gutierrez, M.M.; Giovanazzi, A.; de Groot, A.M.; Kleinjan, M.; van Capel, T.M.M.; Sijts, A.J.A.M.; Taams, L.S.; Garssen, J.; et al. Human milk extracellular vesicles target nodes in interconnected signalling pathways that enhance oral epithelial barrier function and dampen immune responses. J. Extracell. Vesicles 2021, 10 , e12071. [CrossRef] [PubMed]

3. Carr, L.E.; Virmani, M.D.; Rosa, F.; Munblit, D.; Matazel, K.S.; Elolimy, A.A.; Yeruva, L. Role of human milk bioactives on infants' gut and immune health. Front. Immunol. 2021, 12, 604080. [CrossRef] [PubMed]

4. Victora, C.G.; Bahl, R.; Barros, A.J.; França, G.V.; Horton, S.; Krasevec, J.; Murch, S.; Sankar, M.J.; Walker, N.; Rollins, N.C.; et al. Breastfeeding in the 21st century: Epidemiology, mechanisms, and lifelong effect. Lancet 2016, 387, 475-490. [CrossRef]

5. Melnik, B.C.; John, S.M.; Schmitz, G. Milk is not just food but most likely a genetic transfection system activating mTORC1 signaling for postnatal growth. Nutr. J. 2013, 12, 103. [CrossRef]

6. Melnik, B.C. Milk-A nutrient system of mammalian evolution promoting mTORC1-dependent translation. Int. J. Mol. Sci. 2015, 16, 17048-17087. [CrossRef]

7. Melnik, B.C.; Kakulas, F.; Geddes, D.T.; Hartmann, P.E.; John, S.M.; Carrera-Bastos, P.; Cordain, L.; Schmitz, G. Milk miRNAs: Simple nutrients or systemic functional regulators? Nutr. Metab. 2016, 13, 42. [CrossRef]

8. Weber, J.A.; Baxter, D.H.; Zhang, S.; Huang, D.Y.; Huang, K.H.; Lee, M.J.; Galas, D.J.; Wang, K. The microRNA spectrum in 12 body fluids. Clin. Chem. 2010, 56, 1733-1741. [CrossRef]

9. Benmoussa, A.; Ly, S.; Shan, S.T.; Laugier, J.; Boilard, E.; Gilbert, C.; Provost, P. A subset of extracellular vesicles carries the bulk of microRNAs in commercial dairy cow's milk. J. Extracell. Vesicles 2017, 6, 1401897. [CrossRef]

10. Benmoussa, A.; Laugier, J.; Beauparlant, C.J.; Lambert, M.; Droit, A.; Provost, P. Complexity of the microRNA transcriptome of cow milk and milk-derived extracellular vesicles isolated via differential ultracentrifugation. J. Dairy Sci. 2020, $103,16-29$. [CrossRef]

11. De la Torre Gomez, C.; Goreham, R.V.; Bech Serra, J.J.; Nann, T.; Kussmann, M. “Exosomics”—A review of biophysics, biology and biochemistry of exosomes with a focus on human breast milk. Front. Genet. 2018, 9, 92. [CrossRef]

12. Adriano, B.; Cotto, N.M.; Chauhan, N.; Jaggi, M.; Chauhan, S.C.; Yallapu, M.M. Milk exosomes: Nature's abundant nanoplatform for theranostic applications. Bioact. Mater. 2021, 6, 2479-2490. [CrossRef]

13. Alsaweed, M.; Lai, C.T.; Hartmann, P.E.; Geddes, D.T.; Kakulas, F. Human milk miRNAs primarily originate from the mammary gland resulting in unique miRNA profiles of fractionated milk. Sci. Rep. 2016, 6, 20680. [CrossRef]

14. Liao, Y.; Du, X.; Li, J.; Lönnerdal, B. Human milk exosomes and their microRNAs survive digestion in vitro and are taken up by human intestinal cells. Mol. Nutr. Food Res. 2017, 61, 1700082. [CrossRef]

15. Kahn, S.; Liao, Y.; Du, X.; Xu, W.; Li, J.; Lönnerdal, B. Exosomal microRNAs in milk from mothers delivering preterm infants survive in vitro digestion and are taken up by human intestinal cells. Mol. Nutr. Food Res. 2018, 62, e1701050. [CrossRef] 
16. Lönnerdal, B. Human milk microRNAs/exosomes: Composition and biological effects. Nestle Nutr. Inst. Workshop Ser. 2019, 90, 83-92.

17. Sanwlani, R.; Fonseka, P.; Chitti, S.V.; Mathivanan, S. Milk-derived extracellular vesicles in inter-organism, cross-species communication and drug delivery. Proteomes 2020, 8, 11. [CrossRef]

18. Manca, S.; Upadhyaya, B.; Mutai, E.; Desaulniers, A.T.; Cederberg, R.A.; White, B.R.; Zempleni, J. Milk exosomes are bioavailable and distinct microRNA cargos have unique tissue distribution patterns. Sci. Rep. 2018, 8, 11321. [CrossRef]

19. Sadri, M.; Shu, J.; Kachman, S.D.; Cui, J.; Zempleni, J. Milk exosomes and miRNA cross the placenta and promote embryo survival in mice. Reproduction 2020, 160, 501-509. [CrossRef]

20. Golan-Gerstl, R.; Elbaum Shiff, Y.; Moshayoff, V.; Schecter, D.; Leshkowitz, D.; Reif, S. Characterization and biological function of milk-derived miRNAs. Mol. Nutr. Food Res. 2017, 61, 1700009. [CrossRef]

21. Rubio, M.; Bustamante, M.; Hernandez-Ferrer, C.; Fernandez-Orth, D.; Pantano, L.; Sarria, Y.; Piqué-Borras, M.; Vellve, K.; Agramunt, S.; Carreras, R.; et al. Circulating miRNAs, isomiRs and small RNA clusters in human plasma and breast milk. PLoS ONE 2018, 13, e0193527. [CrossRef] [PubMed]

22. Smyczynska, U.; Bartlomiejczyk, M.A.; Stanczak, M.M.; Sztromwasser, P.; Wesolowska, A.; Barbarska, O.; Pawlikowska, E.; Fendler, W. Impact of processing method on donated human breast milk microRNA content. PLoS ONE 2020, 15, e0236126. [CrossRef] [PubMed]

23. Munch, E.M.; Harris, R.A.; Mohammad, M.; Benham, A.L.; Pejerrey, S.M.; Showalter, L.; Hu, M.; Shope, C.D.; Maningat, P.D.; Gunaratne, P.H.; et al. Transcriptome profiling of microRNA by Next-Gen deep sequencing reveals known and novel miRNA species in the lipid fraction of human breast milk. PLoS ONE 2013, 8, e50564. [CrossRef] [PubMed]

24. Chen, Z.; Luo, J.; Sun, S.; Cao, D.; Shi, H.; Loor, J.J. miR-148a and miR-17-5p synergistically regulate milk TAG synthesis via PPARGC1A and PPARA in goat mammary epithelial cells. RNA Biol. 2017, 14, 326-338. [CrossRef] [PubMed]

25. Van Herwijnen, M.J.C.; Driedonks, T.A.P.; Snoek, B.L.; Kroon, A.M.T.; Kleinjan, M.; Jorritsma, R.; Pieterse, C.M.J.; Hoen, E.N.M.N.; Wauben, M.H.M. Abundantly present miRNAs in milk-derived extracellular vesicles are conserved between mammals. Front. Nutr. 2018, 5, 81. [CrossRef]

26. Chen, Z.; Xie, Y.; Luo, J.; Chen, T.; Xi, Q.; Zhang, Y.; Sun, J. Milk exosome-derived miRNAs from water buffalo are implicated in immune response and metabolism process. BMC Vet. Res. 2020, 16, 123. [CrossRef]

27. Reif, S.; Elbaum Shiff, Y.; Golan-Gerstl, R. Milk-derived exosomes (MDEs) have a different biological effect on normal fetal colon epithelial cells compared to colon tumor cells in a miRNA-dependent manner. J. Transl. Med. 2019, 17, 325. [CrossRef]

28. Pan, W.; Zhu, S.; Yuan, M.; Cui, H.; Wang, L.; Luo, X.; Li, J.; Zhou, H.; Tang, Y.; Shen, N. MicroRNA-21 and microRNA-148a contribute to DNA hypomethylation in lupus $\mathrm{CD}^{+} \mathrm{T}$ cells by directly and indirectly targeting DNA methyltransferase 1 . J. Immunol. 2010, 184, 6773-6781. [CrossRef]

29. Melnik, B.C.; Schmitz, G. MicroRNAs: Milk's epigenetic regulators. Best Pract. Res. Clin. Endocrinol. Metab. 2017, 31, 427-442. [CrossRef]

30. Melnik, B.C.; Schmitz, G. Milk's role as an epigenetic regulator in health and disease. Diseases 2017, 5, 12. [CrossRef]

31. Ozkan, H.; Tuzun, F.; Taheri, S.; Korhan, P.; Akokay, P.; Yılmaz, O.; Duman, N.; Özer, E.; Tufan, E.; Kumral, A.; et al. Epigenetic programming through breast milk and its impact on milk-siblings mating. Front. Genet. 2020, 11, 569232. [CrossRef]

32. Zhou, Q.; Li, M.; Wang, X.; Li, Q.; Wang, T.; Zhu, Q.; Zhou, X.; Wang, X.; Gao, X.; Li, X. Immune-related microRNAs are abundant in breast milk exosomes. Int. J. Biol. Sci. 2012, 8, 118-123. [CrossRef]

33. Zempleni, J.; Aguilar-Lozano, A.; Sadri, M.; Sukreet, S.; Manca, S.; Wu, D.; Zhou, F.; Mutai, E. Biological activities of extracellular vesicles and their cargos from bovine and human milk in humans and implications for infants. J. Nutr. 2017, 147, 3-10. [CrossRef]

34. Tomé-Carneiro, J.; Fernández-Alonso, N.; Tomás-Zapico, C.; Visioli, F.; Iglesias-Gutierrez, E.; Dávalos, A. Breast milk microRNAs harsh journey towards potential effects in infant development and maturation. Lipid encapsulation can help. Pharmacol. Res. 2018, 132, 21-32. [CrossRef]

35. Zempleni, J.; Sukreet, S.; Zhou, F.; Wu, D.; Mutai, E. Milk-derived exosomes and metabolic regulation. Annu. Rev. Anim. Biosci. 2019, 7, 245-262. [CrossRef]

36. Benmoussa, A.; Provost, P. Milk microRNAs in health and disease. Compr. Rev. Food Sci. Food Saf. 2019, 18, 703-722. [CrossRef]

37. Galley, J.D.; Besner, G.E. The therapeutic potential of breast milk-derived extracellular vesicles. Nutrients 2020, $12,745$.

38. Kim, K.U.; Kim, W.H.; Jeong, C.H.; Yi, D.Y.; Min, H. More than nutrition: Therapeutic potential of breast milk-derived exosomes in cancer. Int. J. Mol. Sci. 2020, 21, 7327. [CrossRef]

39. Carrillo-Lozano, E.; Sebastián-Valles, F.; Knott-Torcal, C. Circulating microRNAs in breast milk and their potential impact on the infant. Nutrients 2020, 12, 3066. [CrossRef]

40. Kupsco, A.; Prada, D.; Valvi, D.; Hu, L.; Petersen, M.S.; Coull, B.; Grandjean, P.; Weihe, P.; Baccarelli, A.A. Human milk extracellular vesicle miRNA expression and associations with maternal characteristics in a population-based cohort from the Faroe Islands. Sci. Rep. 2021, 11, 5840.

41. O'Reilly, D.; Dorodnykh, D.; Avdeenko, N.V.; Nekliudov, N.A.; Garssen, J.; Elolimy, A.A.; Petrou, L.; Simpson, M.R.; Yeruva, L.; Munblit, D. Perspective: The role of human breast-milk extracellular vesicles in child health and disease. Adv. Nutr. 2021, 12, 59-70. [CrossRef]

42. Leiferman, A.; Shu, J.; Upadhyaya, B.; Cui, J.; Zempleni, J. Storage of extracellular vesicles in human milk, and microRNA profiles in human milk exosomes and infant formulas. J. Pediatr. Gastroenterol. Nutr. 2019, 69, 235-238. [CrossRef] 
43. Mulcahy, L.A.; Pink, R.C.; Carter, D.R. Routes and mechanisms of extracellular vesicle uptake. J. Extracell. Vesicles $2014,3,24641$. [CrossRef]

44. Abels, E.R.; Breakefield, X.O. Introduction to extracellular vesicles: Biogenesis, RNA cargo selection, content, release, and uptake. Cell Mol. Neurobiol. 2016, 36, 301-312. [CrossRef] [PubMed]

45. Jadli, A.S.; Ballasy, N.; Edalat, P.; Patel, V.B. Inside(sight) of tiny communicator: Exosome biogenesis, secretion, and uptake. Mol. Cell Biochem. 2020, 467, 77-94. [CrossRef] [PubMed]

46. Wolf, T.; Baier, S.R.; Zempleni, J. The intestinal transport of bovine milk exosomes is mediated by endocytosis in human colon carcinoma Caco-2 cells and rat small intestinal IEC-6 Cells. J. Nutr. 2015, 145, 2201-2206. [CrossRef] [PubMed]

47. Li, B.; Hock, A.; Wu, R.Y.; Minich, A.; Botts, S.R.; Lee, C.; Antounians, L.; Miyake, H.; Koike, Y.; Chen, Y.; et al. Bovine milk-derived exosomes enhance goblet cell activity and prevent the development of experimental necrotizing enterocolitis. PLoS ONE 2019, 14, e0211431. [CrossRef] [PubMed]

48. Argon, Y.; Bresson, S.E.; Marzec, M.T.; Grimberg, A. Glucose-regulated protein 94 (GRP94): A novel regulator of insulin-like growth factor production. Cells 2020, 9, 1844. [CrossRef] [PubMed]

49. Ghiasi, S.M.; Dahlby, T.; Hede Andersen, C.; Haataja, L.; Petersen, S.; Omar-Hmeadi, M.; Yang, M.; Pihl, C.; Bresson, S.E.; Khilji, M.S.; et al. Endoplasmic reticulum chaperone glucose-regulated protein 94 is essential for proinsulin handling. Diabetes 2019, 68, 747-760. [CrossRef]

50. Liu, B.; Staron, M.; Hong, F.; Wu, B.X.; Sun, S.; Morales, C.; Crosson, C.E.; Tomlinson, S.; Kim, I.; Wu, D.; et al. Essential roles of grp94 in gut homeostasis via chaperoning canonical Wnt pathway. Proc. Natl. Acad. Sci. USA 2013, 110, 6877-6882. [CrossRef]

51. Shelby, R.D.; Cromeens, B.; Rager, T.M.; Besner, G.E. Influence of growth factors on the development of necrotizing enterocolitis. Clin. Perinatol. 2019, 46, 51-64. [CrossRef]

52. Hoeflich, A.; Meyer, Z. Functional analysis of the IGF-system in milk. Best Pract. Res. Clin. Endocrinol. Metab. 2017, 31, 409-418. [CrossRef]

53. Freier, S.; Eran, M.; Reinus, C.; Ariel, I.; Faber, J.; Wilschanski, M.; Braverman, D. Relative expression and localization of the insulin-like growth factor system components in the fetal, child and adult intestine. J. Pediatr. Gastroenterol. Nutr. 2005, 40, 202-209. [CrossRef]

54. Chen, T.; Xie, M.Y.; Sun, J.J.; Ye, R.S.; Cheng, X.; Sun, R.P.; Wei, L.M.; Li, M.; Lin, D.L.; Jiang, Q.Y.; et al. Porcine milk-derived exosomes promote proliferation of intestinal epithelial cells. Sci. Rep. 2016, 6, 33862. [CrossRef]

55. Ozen, S.; Akisu, M.; Baka, M.; Yalaz, M.; Sozmen, E.Y.; Berdeli, A.; Kultursay, N. Insulin-like growth factor attenuates apoptosis and mucosal damage in hypoxia/reoxygenation-induced intestinal injury. Biol. Neonate 2005, 87, 91-96. [CrossRef]

56. Wilkins, H.R.; Ohneda, K.; Keku, T.O.; D'Ercole, A.J.; Fuller, C.R.; Williams, K.L.; Lund, P.K. Reduction of spontaneous and irradiation-induced apoptosis in small intestine of IGF-I transgenic mice. Am. J. Physiol. Gastrointest. Liver Physiol. 2002, 283, G457-G464. [CrossRef]

57. Jeschke, M.G.; Bolder, U.; Chung, D.H.; Przkora, R.; Mueller, U.; Thompson, J.C.; Wolf, S.E.; Herndon, D.N. Gut mucosal homeostasis and cellular mediators after severe thermal trauma and the effect of insulin-like growth factor-I in combination with insulin-like growth factor binding protein-3. Endocrinology 2007, 148, 354-362. [CrossRef]

58. Baregamian, N.; Rychahou, P.G.; Hawkins, H.K.; Evers, B.M.; Chung, D.H. Phosphatidylinositol 3-kinase pathway regulates hypoxia-inducible factor-1 to protect from intestinal injury during necrotizing enterocolitis. Surgery 2007, 142, 295-302. [CrossRef]

59. Tian, F.; Liu, G.R.; Li, N.; Yuan, G. Insulin-like growth factor I reduces the occurrence of necrotizing enterocolitis by reducing inflammatory response and protecting intestinal mucosal barrier in neonatal rats model. Eur. Rev. Med. Pharmacol. Sci. 2017, 21, 4711-4719.

60. Ni, F.; Sun, R.; Fu, B.; Wang, F.; Guo, C.; Tian, Z.; Wei, H. IGF-1 promotes the development and cytotoxic activity of human NK cells. Nat. Commun. 2013, 4, 1479. [CrossRef]

61. Zhang, W.; Frankel, W.L.; Adamson, W.T.; Roth, J.A.; Mantell, M.P.; Bain, A.; Ziegler, T.R.; Smith, R.J.; Rombeau, J.L. Insulin-like growth factor-I improves mucosal structure and function in transplanted rat small intestine. Transplantation 1995, 59, 755-761. [CrossRef]

62. Lorenzo-Zúñiga, V.; Rodríguez-Ortigosa, C.M.; Bartolí, R.; Martínez-Chantar, M.L.; Martínez-Peralta, L.; Pardo, A.; Ojanguren, I.; Quiroga, J.; Planas, R.; Prieto, J. Insulin-like growth factor I improves intestinal barrier function in cirrhotic rats. Gut 2006, 55, 1306-1312. [CrossRef]

63. Hunninghake, G.W.; Doerschug, K.C.; Nymon, A.B.; Schmidt, G.A.; Meyerholz, D.K.; Ashare, A. Insulin-like growth factor-1 levels contribute to the development of bacterial translocation in sepsis. Am. J. Respir. Crit. Care Med. 2010, 182, 517-525. [CrossRef]

64. Corpeleijn, W.E.; van Vliet, I.; de Gast-Bakker, D.A.; van der Schoor, S.R.; Alles, M.S.; Hoijer, M.; Tibboel, D.; van Goudoever, J.B. Effect of enteral IGF-1 supplementation on feeding tolerance, growth, and gut permeability in enterally fed premature neonates. J. Pediatr. Gastroenterol. Nutr. 2008, 46, 184-190. [CrossRef]

65. Rowland, K.J.; Choi, P.M.; Warner, B.W. The role of growth factors in intestinal regeneration and repair in necrotizing enterocolitis. Semin. Pediatr. Surg. 2013, 22, 101-111. [CrossRef]

66. Ouni, M.; Gunes, Y.; Belot, M.P.; Castell, A.L.; Fradin, D.; Bougnères, P. The IGF1 P2 promoter is an epigenetic QTL for circulating IGF1 and human growth. Clin. Epigenetics 2015, 7, 22. 
67. Ouni, M.; Castell, A.L.; Linglart, A.; Bougnères, P. Genetic and epigenetic modulation of growth hormone sensitivity studied with the IGF-1 generation test. J. Clin. Endocrinol. Metab. 2015, 100, E919-E925. [CrossRef]

68. Ouni, M.; Belot, M.P.; Castell, A.L.; Fradin, D.; Bougnères, P. The P2 promoter of the IGF1 gene is a major epigenetic locus for GH responsiveness. Pharmacogenomics J. 2016, 16, 102-106. [CrossRef]

69. Ma, M.; Zhou, Q.J.; Xiong, Y.; Li, B.; Li, X.T. Preeclampsia is associated with hypermethylation of IGF-1 promoter mediated by DNMT1. Am. J. Transl. Res. 2018, 10, 16-39. [PubMed]

70. Yu, S.; Zhao, Z.; Sun, L.; Li, P. Fermentation results in quantitative changes in milk-derived exosomes and different effects on cell growth and survival. J. Agric. Food Chem. 2017, 65, 1220-1228. [CrossRef] [PubMed]

71. Hock, A.; Miyake, H.; Li, B.; Lee, C.; Ermini, L.; Koike, Y.; Chen, Y.; Määttänen, P.; Zani, A.; Pierro, A. Breast milk-derived exosomes promote intestinal epithelial cell growth. J. Pediatr. Surg. 2017, 52, 755-759. [CrossRef] [PubMed]

72. Gao, H.N.; Guo, H.Y.; Zhang, H.; Xie, X.L.; Wen, P.C.; Ren, F.Z. Yak-milk-derived exosomes promote proliferation of intestinal epithelial cells in an hypoxic environment. J. Dairy Sci. 2019, 102, 985-996. [CrossRef]

73. Gao, H.N.; Ren, F.Z.; Wen, P.C.; Xie, L.X.; Wang, R.; Yang, Z.N.; Li, Y.X. Yak milk-derived exosomal microRNAs regulate intestinal epithelial cells on proliferation in hypoxic environment. J. Dairy Sci. 2021, 104, 1291-1303. [CrossRef] [PubMed]

74. Ross, M.; Atalla, H.; Karrow, N.; Mallard, B.A. The bioactivity of colostrum and milk exosomes of high, average, and low immune responder cows on human intestinal epithelial cells. J. Dairy Sci. 2021, 104, 2499-2510. [CrossRef]

75. Barker, N.; van Es, J.H.; Kuipers, J.; Kujala, P.; van den Born, M.; Cozijnsen, M.; Haegebarth, A.; Korving, J.; Begthel, H.; Peters, P.J.; et al. Identification of stem cells in small intestine and colon by marker gene Lgr5. Nature 2007, 449, 1003-1007. [CrossRef]

76. Fernandez Vallone, V.; Leprovots, M.; Ribatallada-Soriano, D.; Gerbier, R.; Lefort, A.; Libert, F.; Vassart, G.; Garcia, M.I. LGR5 controls extracellular matrix production by stem cells in the developing intestine. EMBO Rep. 2020, 21, e49224. [CrossRef]

77. Dong, P.; Zhang, Y.; Yan, D.Y.; Wang, Y.; Xu, X.; Zhao, Y.C.; Xiao, T.T. Protective effects of human milk-derived exosomes on intestinal stem cells damaged by oxidative stress. Cell Transplant. 2020, 29, 963689720912690. [CrossRef]

78. Buckley, A.; Turner, J.R. Cell biology of tight junction barrier regulation and mucosal disease. Cold Spring Harb. Perspect. Biol. 2018, 10, a029314. [CrossRef]

79. Ravisankar, S.; Tatum, R.; Garg, P.M.; Herco, M.; Shekhawat, P.S.; Chen, Y.H. Necrotizing enterocolitis leads to disruption of tight junctions and increase in gut permeability in a mouse model. BMC Pediatr. 2018, 18, 372. [CrossRef]

80. Liu, D.; Xu, Y.; Feng, J.; Yu, J.; Huang, J.; Li, Z. Mucins and tight junctions are severely altered in necrotizing enterocolitis neonates. Am. J. Perinatol. 2020. [CrossRef]

81. Camilleri, M.; Madsen, K.; Spiller, R.; Greenwood-Van Meerveld, B.; Verne, G.N. Intestinal barrier function in health and gastrointestinal disease. Neurogastroenterol. Motil. 2012, 24, 503-512. [CrossRef]

82. Furuse, M.; Hata, M.; Furuse, K.; Yoshida, Y.; Haratake, A.; Sugitani, Y.; Noda, T.; Kubo, A.; Tsukita, S. Claudin-based tight junctions are crucial for the mammalian epidermal barrier: A lesson from claudin-1-deficient mice. J. Cell Biol. 2002, 156, 1099-1111. [CrossRef]

83. Fanning, A.S.; Jameson, B.J.; Jesaitis, L.A.; Anderson, J.M. The tight junction protein ZO-1 establishes a link between the transmembrane protein occludin and the actin cytoskeleton. J. Biol. Chem. 1998, 273, 29745-29753. [CrossRef]

84. Benmoussa, A.; Diallo, I.; Salem, M.; Michel, S.; Gilbert, C.; Sévigny, J.; Provost, P. Concentrates of two subsets of extracellular vesicles from cow's milk modulate symptoms and inflammation in experimental colitis. Sci. Rep. 2019, 9, 14661. [CrossRef]

85. Xie, M.Y.; Chen, T.; Xi, Q.Y.; Hou, L.J.; Luo, J.Y.; Zeng, B.; Li, M.; Sun, J.J.; Zhang, L. Porcine milk exosome miRNAs protect intestinal epithelial cells against deoxynivalenol-induced damage. Biochem. Pharmacol. 2020, 175, 113898. [CrossRef]

86. He, S.; Liu, G.; Zhu, X. Human breast milk-derived exosomes may help maintain intestinal epithelial barrier integrity. Pediatr. Res. 2021. [CrossRef]

87. Cornick, S.; Tawiah, A.; Chadee, K. Roles and regulation of the mucus barrier in the gut. Tissue Barriers 2015, 3, e982426. [CrossRef]

88. Paone, P.; Cani, P.D. Mucus barrier, mucins and gut microbiota: The expected slimy partners? Gut 2020, 69, 2232-2243. [CrossRef]

89. Forstner, G. Signal transduction, packaging and secretion of mucins. Annu. Rev. Physiol. 1995, 57, 585-605. [CrossRef] [PubMed]

90. Johansson, M.E.; Hansson, G.C. Immunological aspects of intestinal mucus and mucins. Nat. Rev. Immunol. 2016, 16, 639-649. [CrossRef] [PubMed]

91. Tong, L.; Hao, H.; Zhang, X.; Zhang, Z.; Lv, Y.; Zhang, L.; Yi, H. Oral administration of bovine milk-derived extracellular vesicles alters the gut microbiota and enhances intestinal immunity in mice. Mol. Nutr. Food Res. 2020, 64, e1901251. [CrossRef] [PubMed]

92. Miyake, H.; Lee, C.; Chusilp, S.; Bhalla, M.; Li, B.; Pitino, M.; Seo, S.; O'Connor, D.L.; Pierro, A. Human breast milk exosomes attenuate intestinal damage. Pediatr. Surg. Int. 2020, 36, 155-163. [CrossRef] [PubMed]

93. Camilleri, M. Leaky gut: Mechanisms, measurement and clinical implications in humans. Gut 2019, 68, 1516-1526. [CrossRef] [PubMed]

94. Hansson, G.C. Mucins and the microbiome. Annu. Rev. Biochem. 2020, 89, 769-793. [CrossRef]

95. Johansson, M.E.V.; Sjövall, H.; Hansson, G.C. The gastrointestinal mucus system in health and disease. Nat. Rev. Gastroenterol. Hepatol. 2013, 10, 352-361. [CrossRef]

96. Pelaseyed, T.; Bergström, J.H.; Gustafsson, J.K.; Ermund, A.; Birchenough, G.M.; Schütte, A.; van der Post, S.; Svensson, F.; Rodríguez-Piñeiro, A.M.; Nyström, E.E.; et al. The mucus and mucins of the goblet cells and enterocytes provide the first defense line of the gastrointestinal tract and interact with the immune system. Immunol. Rev. 2014, 260, 8-20. [CrossRef] 
97. Schroeder, B.O. Fight them or feed them: How the intestinal mucus layer manages the gut microbiota. Gastroenterol. Rep. 2019, 7, 3-12. [CrossRef]

98. Vaishnava, S.; Yamamoto, M.; Severson, K.M.; Ruhn, K.A.; Yu, X.; Koren, O.; Ley, R.; Wakeland, E.K.; Hooper, L.V. The antibacterial lectin RegIIIgamma promotes the spatial segregation of microbiota and host in the intestine. Science 2011, 334, 255-258. [CrossRef]

99. Santaolalla, R.; Abreu, M.T. Innate immunity in the small intestine. Curr. Opin. Gastroenterol. 2012, 28, 124-129. [CrossRef]

100. Friedrich, C.; Mamareli, P.; Thiemann, S.; Kruse, F.; Wang, Z.; Holzmann, B.; Strowig, T.; Sparwasser, T.; Lochner, M. MyD88 signaling in dendritic cells and the intestinal epithelium controls immunity against intestinal infection with C. rodentium. PLoS Pathog. 2017, 13, e1006357. [CrossRef]

101. Ronellenfitsch, S.; Weiß, C.; Frommhold, D.; Koch, L.; Mollenhauer, J.; Poeschl, J.; Müller, H. High DMBT1 concentrations in breast milk correlate with increased risk of infection in preterm and term neonates. BMC Pediatr. 2012, 12, 157. [CrossRef]

102. Chen, C.Y.; Rao, S.S.; Ren, L.; Hu, X.K.; Tan, Y.J.; Hu, Y.; Luo, J.; Liu, Y.W.; Yin, H.; Huang, J.; et al. Exosomal DMBT1 from human urine-derived stem cells facilitates diabetic wound repair by promoting angiogenesis. Theranostics 2018, 8, 1607-1623. [CrossRef]

103. Yu, S.; Zhao, Z.; Xu, X.; Li, M.; Li, P. Characterization of three different types of extracellular vesicles and their impact on bacterial growth. Food Chem. 2019, 272, 372-378. [CrossRef]

104. Zhou, F.; Paz, H.A.; Sadri, M.; Cui, J.; Kachman, S.D.; Fernando, S.C.; Zempleni, J. Dietary bovine milk exosomes elicit changes in bacterial communities in C57BL/6 mice. Am. J. Physiol. Gastrointest. Liver Physiol. 2019, 317, G618-G624. [CrossRef]

105. Zhang, J.; Song, L.; Wang, Y.; Liu, C.; Zhang, L.; Zhu, S.; Liu, S.; Duan, L. Beneficial effect of butyrate-producing Lachnospiraceae on stress-induced visceral hypersensitivity in rats. J. Gastroenterol. Hepatol. 2019, 34, 1368-1376. [CrossRef]

106. Sasaki, K.; Inoue, J.; Sasaki, D.; Hoshi, N.; Shirai, T.; Fukuda, I.; Azuma, T.; Kondo, A.; Osawa, R. Construction of a model culture system of human colonic microbiota to detect decreased Lachnospiraceae abundance and butyrogenesis in the feces of ulcerative colitis patients. Biotechnol. J. 2019, 14, e1800555. [CrossRef]

107. Arpaia, N.; Campbell, C.; Fan, X.; Dikiy, S.; van der Veeken, J.; deRoos, P.; Liu, H.; Cross, J.R.; Pfeffer, K.; Coffer, P.J.; et al. Metabolites produced by commensal bacteria promote peripheral regulatory T-cell generation. Nature 2013, 504, 451-455. [CrossRef]

108. Furusawa, Y.; Obata, Y.; Fukuda, S.; Endo, T.A.; Nakato, G.; Takahashi, D.; Nakanishi, Y.; Uetake, C.; Kato, K.; Kato, T.; et al. Commensal microbe-derived butyrate induces the differentiation of colonic regulatory T cells. Nature 2013, 504, 446-450. [CrossRef]

109. Ruohtula, T.; de Goffau, M.C.; Nieminen, J.K.; Honkanen, J.; Siljander, H.; Hämäläinen, A.M.; Peet, A.; Tillmann, V.; Ilonen, J.; Niemelä, O.; et al. Maturation of gut microbiota and circulating regulatory T cells and development of IgE sensitization in early life. Front. Immunol. 2019, 10, 2494. [CrossRef]

110. Feuerer, M.; Hill, J.A.; Mathis, D.; Benoist, C. Foxp3+ regulatory T cells:differentiation, specification, subphenotypes. Nat. Immunol. 2009, 10, 689-695. [CrossRef]

111. Yamashiro, Y. Gut microbiota in health and disease. Ann. Nutr. Metab. 2017, 71, 242-246. [CrossRef]

112. Figliuolo da Paz, V.R.; Jamwal, D.R.; Kiela, P.R. Intestinal regulatory T cells. Adv. Exp. Med. Biol. 2021, 1278, 141-190. [PubMed]

113. Weitkamp, J.H.; Rudzinski, E.; Koyama, T.; Correa, H.; Matta, P.; Alberty, B.; Polk, D.B. Ontogeny of FOXP3(+) regulatory T cells in the postnatal human small intestinal and large intestinal lamina propria. Pediatr. Dev. Pathol. 2009, 12, 443-449. [CrossRef] [PubMed]

114. Tanoue, T.; Atarashi, K.; Honda, K. Development and maintenance of intestinal regulatory T cells. Nat. Rev. Immunol. 2016, 16, 295-309. [CrossRef]

115. Hadis, U.; Wahl, B.; Schulz, O.; Hardtke-Wolenski, M.; Schippers, A.; Wagner, N.; Müller, W.; Sparwasser, T.; Förster, R.; Pabst, O. Intestinal tolerance requires gut homing and expansion of FoxP3+ regulatory T cells in the lamina propria. Immunity 2011, 34, 237-246. [CrossRef]

116. Tordesillas, L.; Berin, M.C. Mechanisms of oral tolerance. Clin. Rev. Allergy Immunol. 2018, 55, 107-117. [CrossRef] [PubMed]

117. Huehn, J.; Beyer, M. Epigenetic and transcriptional control of Foxp3+ regulatory T cells. Semin. Immunol. 2015, $27,10-18$. [CrossRef]

118. Bellanti, J.A.; Li, D. Treg cells and epigenetic regulation. Adv. Exp. Med. Biol. 2021, 1278, 95-114.

119. Polansky, J.K.; Kretschmer, K.; Freyer, J.; Floess, S.; Garbe, A.; Baron, U.; Olek, S.; Hamann, A.; von Boehmer, H.; Huehn, J. DNA methylation controls Foxp3 gene expression. Eur. J. Immunol. 2008, 38, 1654-1663. [CrossRef]

120. Toker, A.; Engelbert, D.; Garg, G.; Polansky, J.K.; Floess, S.; Miyao, T.; Baron, U.; Düber, S.; Geffers, R.; Giehr, P.; et al. Active demethylation of the Foxp3 locus leads to the generation of stable regulatory T cells within the thymus. J. Immunol. 2013, 190, 3180-3188. [CrossRef]

121. Schreiber, L.; Pietzsch, B.; Floess, S.; Farah, C.; Jänsch, L.; Schmitz, I.; Huehn, J. The Treg-specific demethylated region stabilizes Foxp3 expression independently of NF-kB signaling. PLoS ONE 2014, 9, e88318. [CrossRef]

122. Lal, G.; Bromberg, J.S. Epigenetic mechanisms of regulation of Foxp3 expression. Blood 2009, 114, 3727-3735. [CrossRef]

123. Lal, G.; Zhang, N.; van der Touw, W.; Ding, Y.; Ju, W.; Bottinger, E.P.; Reid, S.P.; Levy, D.E.; Bromberg, J.S. Epigenetic regulation of Foxp3 expression in regulatory T cells by DNA methylation. J. Immunol. 2009, 182, 259-273. [CrossRef]

124. Melnik, B.C.; John, S.M.; Schmitz, G. Milk: An exosomal microRNA transmitter promoting thymic regulatory T cell maturation preventing the development of atopy? J. Transl. Med. 2014, 12, 43. [CrossRef] 
125. Melnik, B.C.; John, S.M.; Carrera-Bastos, P.; Schmitz, G. Milk: A postnatal imprinting system stabilizing FoxP3 expression and regulatory T cell differentiation. Clin. Transl. Allergy 2016, 6, 18. [CrossRef]

126. Robbins, P.D.; Morelli, A.E. Regulation of immune responses by extracellular vesicles. Nat. Rev. Immunol. 2014, 14, 195-208. [CrossRef]

127. Seo, N. Exosome-mediated immune regulation and its clinical application. Trends Immunother. 2020, 4, 36-41. [CrossRef]

128. Wani, S.; Man Law, I.K.; Pothoulakis, C. Role and mechanisms of exosomal miRNAs in IBD pathophysiology. Am. J. Physiol. Gastrointest. Liver Physiol. 2020, 319, G646-G654. [CrossRef]

129. Ocansey, D.K.W.; Zhang, L.; Wang, Y.; Yan, Y.; Qian, H.; Zhang, X.; Xu, W.; Mao, F. Exosome-mediated effects and applications in inflammatory bowel disease. Biol. Rev. Camb. Philos. Soc. 2020, 95, 1287-1307. [CrossRef]

130. Admyre, C.; Johansson, S.M.; Qazi, K.R.; Filén, J.J.; Lahesmaa, R.; Norman, M.; Neve, E.P.; Scheynius, A.; Gabrielsson, S. Exosomes with immune modulatory features are present in human breast milk. J. Immunol. 2007, 179, 1969-1978. [CrossRef]

131. Tooley, K.L.; El-Merhibi, A.; Cummins, A.G.; Grose, R.H.; Lymn, K.A.; DeNichilo, M.; Penttila, I.A. Maternal milk, but not formula, regulates the immune response to beta-lactoglobulin in allergy-prone rat pups. J. Nutr. 2009, 139, 2145-2151. [CrossRef]

132. Paparo, L.; Nocerino, R.; Cosenza, L.; Aitoro, R.; D’Argenio, V.; Del Monaco, V.; Di Scala, C.; Amoroso, A.; Di Costanzo, M.; Salvatore, F.; et al. Epigenetic features of FoxP3 in children with cow's milk allergy. Clin. Epigenetics 2016, 8, 86. [CrossRef]

133. Kanjarawi, R.; Dercamp, C.; Etchart, N.; Adel-Patient, K.; Nicolas, J.F.; Dubois, B.; Kaiserlian, D. Regulatory T cells control type I food allergy to beta-lactoglobulin in mice. Int. Arch. Allergy Immunol. 2011, 156, 387-396. [CrossRef]

134. Wang, M.; Yang, I.V.; Davidson, E.J.; Joetham, A.; Takeda, K.; O'Connor, B.P.; Gelfand, E.W. Forkhead box protein 3 demethylation is associated with tolerance induction in peanut-induced intestinal allergy. J. Allergy Clin. Immunol. 2018, 141, 659-670. [CrossRef]

135. Okoye, I.S.; Coomes, S.M.; Pelly, V.S.; Czieso, S.; Papayannopoulos, V.; Tolmachova, T.; Seabra, M.C.; Wilson, M.S. MicroRNAcontaining T-regulatory-cell-derived exosomes suppress pathogenic T helper 1 cells. Immunity 2014, 41, 89-103. [CrossRef]

136. Lluis, A.; Depner, M.; Gaugler, B.; Saas, P.; Casaca, V.I.; Raedler, D.; Michel, S.; Tost, J.; Liu, J.; Genuneit, J.; et al. Increased regulatory T-cell numbers are associated with farm milk exposure and lower atopic sensitization and asthma in childhood. J. Allergy Clin. Immunol. 2014, 133, 551-559.

137. Loss, G.; Apprich, S.; Waser, M.; Kneifel, W.; Genuneit, J.; Büchele, G.; Weber, J.; Sozanska, B.; Danielewicz, H.; Horak, E.; et al. The protective effect of farm milk consumption on childhood asthma and atopy: The GABRIELA study. J. Allergy Clin. Immunol. 2011, 128, 766-773. [CrossRef]

138. Brick, T.; Hettinga, K.; Kirchner, B.; Pfaffl, M.W.; Ege, M.J. The beneficial effect of farm milk consumption on asthma, allergies, and infections: From meta-analysis of evidence to clinical trial. J. Allergy Clin. Immunol. Pract. 2020, 8, 878-889. [CrossRef]

139. Kirchner, B.; Pfaffl, M.W.; Dumpler, J.; von Mutius, E.; Ege, M.J. microRNA in native and processed cow's milk and its implication for the farm milk effect on asthma. J. Allergy Clin. Immunol. 2016, 137, 1893-1895. [CrossRef]

140. Kleinjan, M.; van Herwijnen, M.J.; Libregts, S.F.; van Neerven, R.J.; Feitsma, A.L.; Wauben, M.H. Regular industrial processing of bovine milk impacts the integrity and molecular composition of extracellular vesicles. J. Nutr. 2021. [CrossRef]

141. Sozańska, B.; Pearce, N.; Dudek, K.; Cullinan, P. Consumption of unpasteurized milk and its effects on atopy and asthma in children and adult inhabitants in rural Poland. Allergy 2013, 68, 644-650. [CrossRef] [PubMed]

142. Ismail, R.I.H.; Awad, H.A.; Imam, S.S.; Gad, G.I.; Aboushady, N.M.; Abdou, R.M.; Eissa, D.S.; Azzam, N.T.; Barakat, M.M.; Yassin, M.M.; et al. Gut priming with bovine colostrum and T regulatory cells in preterm neonates: A randomized controlled trial. Pediatr. Res. 2021. [CrossRef] [PubMed]

143. Zheng, S.G.; Gray, J.D.; Ohtsuka, K.; Yamagiwa, S.; Horwitz, D.A. Generation ex vivo of TGF-beta-producing regulatory T cells from CD4+CD25- precursors. J. Immunol. 2002, 169, 4183-4189. [CrossRef] [PubMed]

144. Zheng, S.G.; Wang, J.H.; Gray, J.D.; Soucier, H.; Horwitz, D.A. Natural and induced CD4+CD25+ cells educate CD4+CD25- cells to develop suppressive activity: The role of IL-2, TGF-beta, and IL-10. J. Immunol. 2004, 172, 5213-5221. [CrossRef] [PubMed]

145. Kanamori, M.; Nakatsukasa, H.; Okada, M.; Lu, Q.; Yoshimura, A. Induced regulatory T cells: Their development, stability, and applications. Trends Immunol. 2016, 37, 803-811. [CrossRef]

146. Li, C.; Ebert, P.J.; Li, Q.J. T cell receptor (TCR) and transforming growth factor $\beta$ (TGF- $\beta$ ) signaling converge on DNA (cytosine5)-methyltransferase to control forkhead box protein 3 (foxp3) locus methylation and inducible regulatory T cell differentiation. J. Biol. Chem. 2013, 288, 19127-19139. [CrossRef]

147. Pieters, B.C.; Arntz, O.J.; Bennink, M.B.; Broeren, M.G.; van Caam, A.P.; Koenders, M.I.; van Lent, P.L.; van den Berg, W.B.; de Vries, M.; van der Kraan, P.M.; et al. Commercial cow milk contains physically stable extracellular vesicles expressing immunoregulatory TGF- $\beta$. PLoS ONE 2015, 10, e0121123. [CrossRef]

148. Reif, S.; Elbaum-Shiff, Y.; Koroukhov, N.; Shilo, I.; Musseri, M.; Golan-Gerstl, R. Cow and human milk-derived exosomes ameliorate colitis in DSS murine model. Nutrients 2020, 12, 2589. [CrossRef]

149. Qin, W.; Tsukasaki, Y.; Dasgupta, S.; Mukhopadhyay, N.; Ikebe, M.; Sauter, E.R. Exosomes in human breast milk promote EMT. Clin. Cancer Res. 2016, 22, 4517-4524. [CrossRef]

150. Kalliomäki, M.; Ouwehand, A.; Arvilommi, H.; Kero, P.; Isolauri, E. Transforming growth factor-beta in breast milk: A potential regulator of atopic disease at an early age. J. Allergy Clin. Immunol. 1999, 104, 1251-1257. [CrossRef]

151. Rigotti, E.; Piacentini, G.L.; Ress, M.; Pigozzi, R.; Boner, A.L.; Peroni, D.G. Transforming growth factor-beta and interleukin-10 in breast milk and development of atopic diseases in infants. Clin. Exp. Allergy 2006, 36, 614-618. [CrossRef] 
152. Kohlhaas, S.; Garden, O.A.; Scudamore, C.; Turner, M.; Okkenhaug, K.; Vigorito, E. Cutting edge: The Foxp3 target miR-155 contributes to the development of regulatory T cells. J. Immunol. 2009, 182, 2578-2582. [CrossRef]

153. Yao, R.; Ma, Y.L.; Liang, W.; Li, H.H.; Ma, Z.J.; Yu, X.; Liao, Y.H. MicroRNA-155 modulates Treg and Th17 cells differentiation and Th17 cell function by targeting SOCS1. PLOS ONE 2012, 7, e46082. [CrossRef]

154. Na, R.S.; E, G.X.; Sun, W.; Sun, X.W.; Qiu, X.Y.; Chen, L.P.; Huang, Y.F. Expressional analysis of immune-related miRNAs in breast milk. Genet. Mol. Res. 2015, 14, 11371-11376. [CrossRef]

155. Izumi, H.; Kosaka, N.; Shimizu, T.; Sekine, K.; Ochiya, T.; Takase, M. Bovine milk contains microRNA and messenger RNA that are stable under degradative conditions. J. Dairy Sci. 2012, 95, 4831-4841. [CrossRef]

156. Lu, L.F.; Thai, T.H.; Calado, D.P.; Chaudhry, A.; Kubo, M.; Tanaka, K.; Loeb, G.B.; Lee, H.; Yoshimura, A.; Rajewsky, K.; et al. Foxp3-dependent microRNA155 confers competitive fitness to regulatory T cells by targeting SOCS1 protein. Immunity 2009, 30, 80-91. [CrossRef]

157. Zeng, Q.; Liu, W.; Luo, R.; Lu, G. MicroRNA-181a and microRNA-155 are involved in the regulation of the differentiation and function of regulatory $T$ cells in allergic rhinitis children. Pediatr. Allergy Immunol. 2019, 30, 434-442. [CrossRef]

158. Li, D.P.; Fan, J.; Wu, Y.J.; Xie, Y.F.; Zha, J.M.; Zhou, X.M. MiR-155 up-regulated by TGF- $\beta$ promotes epithelial-mesenchymal transition, invasion and metastasis of human hepatocellular carcinoma cells in vitro. Am. J. Transl. Res. 2017, 9, $2956-2965$.

159. Elton, T.S.; Selemon, H.; Elton, S.M.; Parinandi, N.L. Regulation of the MIR155 host gene in physiological and pathological processes. Gene 2013, 532, 1-12. [CrossRef]

160. O'Connor, E.B.; Muñoz-Wolf, N.; Leon, G.; Lavelle, E.C.; Mills, K.H.G.; Walsh, P.T.; Porter, R.K. UCP3 reciprocally controls CD4+ Th17 and Treg cell differentiation. PLoS ONE 2020, 15, e0239713. [CrossRef]

161. Arntz, O.J.; Pieters, B.C.; Oliveira, M.C.; Broeren, M.G.; Bennink, M.B.; de Vries, M.; van Lent, P.L.; Koenders, M.I.; van den Berg, W.B.; van der Kraan, P.M.; et al. Oral administration of bovine milk derived extracellular vesicles attenuates arthritis in two mouse models. Mol. Nutr. Food Res. 2015, 59, 1701-1712. [CrossRef] [PubMed]

162. Xie, M.Y.; Hou, L.J.; Sun, J.J.; Zeng, B.; Xi, Q.Y.; Luo, J.Y.; Chen, T.; Zhang, Y.L. Porcine milk exosome miRNAs attenuate LPS-induced apoptosis through inhibiting TLR4/NF-kB and p53 pathways in intestinal epithelial cells. J. Agric. Food Chem. 2019, 67, 9477-9491. [CrossRef] [PubMed]

163. Gao, R.; Zhang, R.; Qian, T.; Peng, X.; He, W.; Zheng, S.; Cao, Y.; Pierro, A.; Shen, C. A comparison of exosomes derived from different periods breast milk on protecting against intestinal organoid injury. Pediatr. Surg. Int. 2019, 35, 1363-1368. [CrossRef] [PubMed]

164. Chen, X.; Gao, C.; Li, H.; Huang, L.; Sun, Q.; Dong, Y.; Tian, C.; Gao, S.; Dong, H.; Guan, D.; et al. Identification and characterization of microRNAs in raw milk during different periods of lactation, commercial fluid, and powdered milk products. Cell Res. 2010, 20, 1128-1137. [CrossRef]

165. Taganov, K.D.; Boldin, M.P.; Chang, K.J.; Baltimore, D. NF-kappaB-dependent induction of microRNA miR-146, an inhibitor targeted to signaling proteins of innate immune responses. Proc. Natl. Acad. Sci. USA 2006, 103, 12481-12486. [CrossRef]

166. Hou, J.; Wang, P.; Lin, L.; Liu, X.; Ma, F.; An, H.; Wang, Z.; Cao, X. MicroRNA-146a feedback inhibits RIG-I-dependent type I IFN production in macrophages by targeting TRAF6, IRAK1, and IRAK2. J. Immunol. 2009, 183, 2150-2158. [CrossRef]

167. O'Connell, R.M.; Taganov, K.D.; Boldin, M.P.; Cheng, G.; Baltimore, D. MicroRNA-155 is induced during the macrophage inflammatory response. Proc. Natl. Acad. Sci. USA 2007, 104, 1604-1609. [CrossRef]

168. Tili, E.; Michaille, J.J.; Cimino, A.; Costinean, S.; Dumitru, C.D.; Adair, B.; Fabbri, M.; Alder, H.; Liu, C.G.; Calin, G.A.; et al. Modulation of miR-155 and miR-125b levels following lipopolysaccharide/TNF-alpha stimulation and their possible roles in regulating the response to endotoxin shock. J. Immunol. 2007, 179, 5082-5089. [CrossRef]

169. Sheedy, F.J.; Palsson-McDermott, E.; Hennessy, E.J.; Martin, C.; O’Leary, J.J.; Ruan, Q.; Johnson, D.S.; Chen, Y.; O’Neill, L.A. Negative regulation of TLR4 via targeting of the proinflammatory tumor suppressor PDCD4 by the microRNA miR-21. Nat. Immunol. 2010, 11, 141-147. [CrossRef]

170. Herrmann, T.L.; Morita, C.T.; Lee, K.; Kusner, D.J. Calmodulin kinase II regulates the maturation and antigen presentation of human dendritic cells. J. Leukoc. Biol. 2005, 78, 1397-1407. [CrossRef]

171. Turner, M.L.; Schnorfeil, F.M.; Brocker, T. MicroRNAs regulate dendritic cell differentiation and function. J. Immunol. 2011, 187, 3911-3917. [CrossRef]

172. Liu, X.; Zhan, Z.; Xu, L.; Ma, F.; Li, D.; Guo, Z.; Li, N.; Cao, X. MicroRNA-148/152 impair innate response and antigen presentation of TLR-triggered dendritic cells by targeting CaMKII $\alpha$. J. Immunol. 2010, 185, 7244-7251. [CrossRef]

173. Herrmann, T.L.; Agrawal, R.S.; Connolly, S.F.; McCaffrey, R.L.; Schlomann, J.; Kusner, D.J. MHC Class II levels and intracellular localization in human dendritic cells are regulated by calmodulin kinase II. J. Leukoc. Biol. 2007, 82, 686-699. [CrossRef]

174. Hughes, K.; Edin, S.; Antonsson, A.; Grundström, T. Calmodulin-dependent kinase II mediates T cell receptor/CD3- and phorbol ester-induced activation of IkappaB kinase. J. Biol. Chem. 2001, 276, 36008-36013. [CrossRef]

175. Ishiguro, K.; Green, T.; Rapley, J.; Wachtel, H.; Giallourakis, C.; Landry, A.; Cao, Z.; Lu, N.; Takafumi, A.; Goto, H.; et al. $\mathrm{Ca}+$ /calmodulin-dependent protein kinase II is a modulator of CARMA1-mediated NF-kappaB activation. Mol. Cell. Biol. 2006, 26, 5497-5508. [CrossRef]

176. Patel, V.; Carrion, K.; Hollands, A.; Hinton, A.; Gallegos, T.; Dyo, J.; Sasik, R.; Leire, E.; Hardiman, G.; Mohamed, S.A.; et al. The stretch responsive microRNA miR-148a-3p is a novel repressor of IKBKB, NF- $\mathrm{KB}$ signaling, and inflammatory gene expression in human aortic valve cells. FASEB J. 2015, 29, 1859-1868. [CrossRef] 
177. Lawrence, T. The nuclear factor NF-kappaB pathway in inflammation. Cold Spring Harb. Perspect. Biol. 2009, 1, a001651. [CrossRef]

178. Wullaert, A.; Bonnet, M.C.; Pasparakis, M. NF-kB in the regulation of epithelial homeostasis and inflammation. Cell Res. 2011, 21, 146-158. [CrossRef]

179. Bettelli, E.; Dastrange, M.; Oukka, M. Foxp3 interacts with nuclear factor of activated T cells and NF-kappa B to repress cytokine gene expression and effector functions of T helper cells. Proc. Natl. Acad. Sci. USA 2005, 102, 5138-5143. [CrossRef]

180. Kim, C.H. FOXP3 and its role in the immune system. Adv. Exp. Med. Biol. 2009, 665, 17-29.

181. Auphan, N.; DiDonato, J.A.; Rosette, C.; Helmberg, A.; Karin, M. Immunosuppression by glucocorticoids: Inhibition of NF-kappa B activity through induction of I kappa B synthesis. Science 1995, 270, 286-290. [CrossRef]

182. Scheinman, R.I.; Cogswell, P.C.; Lofquist, A.K.; Baldwin, A.S., Jr. Role of transcriptional activation of I kappa B alpha in mediation of immunosuppression by glucocorticoids. Science 1995, 270, 283-286. [CrossRef]

183. Almawi, W.Y.; Melemedjian, O.K. Negative regulation of nuclear factor-kappaB activation and function by glucocorticoids. J. Mol. Endocrinol. 2002, 28, 69-78. [CrossRef]

184. Carney, M.C.; Tarasiuk, A.; DiAngelo, S.L.; Silveyra, P.; Podany, A.; Birch, L.L.; Paul, I.M.; Kelleher, S.; Hicks, S.D. Metabolismrelated microRNAs in maternal breast milk are influenced by premature delivery. Pediatr. Res. 2017, 82, 226-236. [CrossRef]

185. Huang, Z.P.; Wang, D.Z. miR-22 in cardiac remodeling and disease. Trends Cardiovasc. Med. 2014, 24, 267-272. [CrossRef]

186. Diniz, G.P.; Huang, Z.P.; Liu, J.; Chen, J.; Ding, J.; Fonseca, R.I.; Barreto-Chaves, M.L.; Donato, J., Jr.; Hu, X.; Wang, D.Z. Loss of microRNA-22 prevents high-fat diet induced dyslipidemia and increases energy expenditure without affecting cardiac hypertrophy. Clin. Sci. 2017, 131, 2885-2900. [CrossRef]

187. Yang, Z.; Qin, W.; Huo, J.; Zhuo, Q.; Wang, J.; Wang, L. MiR-22 modulates the expression of lipogenesis-related genes and promotes hepatic steatosis in vitro. FEBS Open Bio 2021, 11, 322-332. [CrossRef]

188. Thibonnier, M.; Esau, C.; Ghosh, S.; Wargent, E.; Stocker, C. Metabolic and energetic benefits of microRNA-22 inhibition. BMJ Open Diabetes Res. Care 2020, 8, e001478. [CrossRef] [PubMed]

189. Lin, J.; Huo, R.; Xiao, L.; Zhu, X.; Xie, J.; Sun, S.; He, Y.; Zhang, J.; Sun, Y.; Zhou, Z.; et al. A novel p53/microRNA-22/Cyr61 axis in synovial cells regulates inflammation in rheumatoid arthritis. Arthritis Rheumatol. 2014, 66, 49-59. [CrossRef] [PubMed]

190. Emre, Y.; Imhof, B.A. Matricellular protein CCN1/CYR61: A new player in inflammation and leukocyte trafficking. Semin. Immunopathol. 2014, 36, 253-259. [CrossRef] [PubMed]

191. Hu, T.; Chen, B.; Zhou, S.; Mao, J. Simvastatin inhibits inflammatory response in lipopolysaccharide (LPS)-stimulated RAW264.7 macrophages through the microRNA-22/Cyr61 axis. Int. J. Clin. Exp. Pathol. 2018, 11, 3925-3933.

192. Shegarfi, H.; Krohn, C.D.; Gundersen, Y.; Kjeldsen, S.F.; Hviid, C.V.; Ruud, T.E.; Aasen, A.O. Regulation of CCN1 (Cyr61) in a porcine model of intestinal ischemia/reperfusion. Innate Immun. 2015, 21, 453-462. [CrossRef]

193. Yang, J.; Fan, Z.; Yang, J.; Ding, J.; Yang, C.; Chen, L. microRNA-22 attenuates myocardial ischemia-reperfusion injury via an anti-inflammatory mechanism in rats. Exp. Ther. Med. 2016, 12, 3249-3255. [CrossRef]

194. Yang, J.; Chen, L.; Yang, J.; Ding, J.; Li, S.; Wu, H.; Zhang, J.; Fan, Z.; Dong, W.; Li, X. MicroRNA-22 targeting CBP protects against myocardial ischemia-reperfusion injury through anti-apoptosis in rats. Mol. Biol. Rep. 2014, 41, 555-561. [CrossRef]

195. Bai, T.; Chen, C.C.; Lau, L.F. Matricellular protein CCN1 activates a proinflammatory genetic program in murine macrophages. J. Immunol. 2010, 184, 3223-3232. [CrossRef]

196. Yu, H.; Wu, M.; Zhao, P.; Huang, Y.; Wang, W.; Yin, W. Neuroprotective effects of viral overexpression of microRNA-22 in rat and cell models of cerebral ischemia-reperfusion injury. J. Cell Biochem. 2015, 116, 233-241. [CrossRef]

197. Takata, A.; Otsuka, M.; Kojima, K.; Yoshikawa, T.; Kishikawa, T.; Yoshida, H.; Koike, K. MicroRNA-22 and microRNA-140

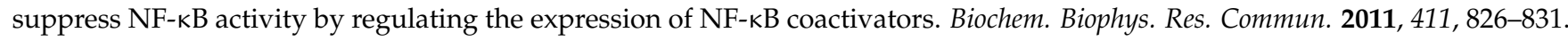
[CrossRef]

198. Liang, X.; Liu, Y.; Mei, S.; Zhang, M.; Xin, J.; Zhang, Y.; Yang, R. MicroRNA-22 impairs anti-tumor ability of dendritic cells by targeting p38. PLoS ONE 2015, 10, e0121510. [CrossRef]

199. Zhou, Y.; Yu, Z.; Wang, X.; Chen, W.; Liu, Y.; Zhang, Y.; Yin, J.; Han, S. Exosomal circRNAs contribute to intestinal development via the VEGF signalling pathway in human term and preterm colostrum. Aging 2021. [CrossRef]

200. Zeng, B.; Chen, T.; Xie, M.Y.; Luo, J.Y.; He, J.J.; Xi, Q.Y.; Sun, J.J.; Zhang, Y.L. Exploration of long noncoding RNA in bovine milk exosomes and their stability during digestion in vitro. J. Dairy Sci. 2019, 102, 6726-6737. [CrossRef]

201. Zeng, B.; Chen, T.; Luo, J.; Xie, M.; Wei, L.; Xi, Q.; Sun, J.; Zhang, Y. Exploration of long non-coding RNAs and circular RNAs in porcine milk exosomes. Front. Genet. 2020, 11, 652. [CrossRef]

202. Zhu, P.; Zhu, X.; Wu, J.; He, L.; Lu, T.; Wang, Y.; Liu, B.; Ye, B.; Sun, L.; Fan, D.; et al. IL-13 secreted by ILC2s promotes the self-renewal of intestinal stem cells through circular RNA circPan3. Nat. Immunol. 2019, 20, 183-194. [CrossRef]

203. Rankin, C.R.; Lokhandwala, Z.A.; Huang, R.; Pekow, J.; Pothoulakis, C.; Padua, D. Linear and circular CDKN2B-AS1 expression is associated with inflammatory bowel disease and participates in intestinal barrier formation. Life Sci. 2019, 231, 116571. [CrossRef]

204. Marell, P.S.; Blohowiak, S.E.; Evans, M.D.; Georgieff, M.K.; Kling, P.J.; Tran, P.V. Cord blood-derived exosomal CNTN2 and BDNF: Potential molecular markers for brain health of neonates at risk for iron deficiency. Nutrients 2019, 11, 2478. [CrossRef]

205. Lu, D.; Xu, A.D. Mini Review: Circular RNAs as potential clinical biomarkers for disorders in the central nervous system. Front. Genet. 2016, 7, 53. [CrossRef]

206. Rich, B.S.; Dolgin, S.E. Necrotizing enterocolitis. Pediatr. Rev. 2017, 38, 552-559. [CrossRef] 
207. Jin, Y.T.; Duan, Y.; Deng, X.K.; Lin, J. Prevention of necrotizing enterocolitis in premature infants-An updated review. World J. Clin. Pediatr. 2019, 8, 23-32. [CrossRef]

208. Markel, T.A.; Martin, C.A.; Chaaban, H.; Canvasser, J.; Tanner, H.; Denchik, H.; Good, M. New directions in necrotizing enterocolitis with early-stage investigators. Pediatr. Res. 2020, 88 (Suppl. S1), 35-40. [CrossRef]

209. Chen, Y.; Koike, Y.; Chi, L.; Ahmed, A.; Miyake, H.; Li, B.; Lee, C.; Delgado-Olguín, P.; Pierro, A. Formula feeding and immature gut microcirculation promote intestinal hypoxia, leading to necrotizing enterocolitis. Dis. Model. Mech. 2019, 12, dmm040998. [CrossRef]

210. Neu, J.; Pammi, M. Necrotizing enterocolitis: The intestinal microbiome, metabolome and inflammatory mediators. Semin. Fetal Neonatal Med. 2018, 23, 400-405. [CrossRef]

211. Baranowski, J.R.; Claud, E.C. Necrotizing enterocolitis and the preterm infant microbiome. Adv. Exp. Med. Biol. 2019, 1125, 25-36. [PubMed]

212. Martin, C.R.; Walker, W.A. Intestinal immune defences and the inflammatory response in necrotising enterocolitis. Semin. Fetal Neonatal Med. 2006, 11, 369-377. [CrossRef] [PubMed]

213. Denning, T.L.; Bhatia, A.M.; Kane, A.F.; Patel, R.M.; Denning, P.W. Pathogenesis of NEC: Role of the innate and adaptive immune response. Semin. Perinatol. 2017, 41, 15-28. [CrossRef]

214. Anand, R.J.; Leaphart, C.L.; Mollen, K.P.; Hackam, D.J. The role of the intestinal barrier in the pathogenesis of necrotizing enterocolitis. Shock 2007, 27, 124-133. [CrossRef]

215. Hackam, D.J.; Sodhi, C.P. Toll-like receptor-mediated intestinal inflammatory imbalance in the pathogenesis of necrotizing enterocolitis. Cell Mol. Gastroenterol. Hepatol. 2018, 6, 229-238. [CrossRef] [PubMed]

216. Egan, C.E.; Sodhi, C.P.; Good, M.; Lin, J.; Jia, H.; Yamaguchi, Y.; Lu, P.; Ma, C.; Branca, M.F.; Weyandt, S.; et al. Toll-like receptor 4-mediated lymphocyte influxinduces neonatal necrotizing enterocolitis. J. Clin. Invest. 2016, 126, 495-508. [CrossRef] [PubMed]

217. Yazji, I.; Sodhi, C.P.; Lee, E.K.; Good, M.; Egan, C.E.; Afrazi, A.; Neal, M.D.; Jia, H.; Lin, J.; Ma, C.; et al. Endothelial TLR4 activation impairs intestinal microcirculatory perfusion in necrotizing enterocolitis via eNOS-NO-nitrite signaling. Proc. Natl. Acad. Sci. USA 2013, 110, 9451-9456. [CrossRef] [PubMed]

218. Chen, Y.; Koike, Y.; Miyake, H.; Li, B.; Lee, C.; Hock, A.; Zani, A.; Pierro, A. Formula feeding and systemic hypoxia synergistically induce intestinal hypoxia in experimental necrotizing enterocolitis. Pediatr. Surg. Int. 2016, 32, 1115-1119. [CrossRef]

219. Ma, F.; Li, S.; Gao, X.; Zhou, J.; Zhu, X.; Wang, D.; Cai, Y.; Li, F.; Yang, Q.; Gu, X.; et al. Interleukin-6-mediated CCR9+interleukin17-producing regulatory $\mathrm{T}$ cells polarization increases the severity of necrotizing enterocolitis. EBioMedicine 2019, 44, 71-85. [CrossRef]

220. Pang, Y.; Du, X.; Xu, X.; Wang, M.; Li, Z. Monocyte activation and inflammation can exacerbate Treg/Th17 imbalance in infants with neonatal necrotizing enterocolitis. Int. Immunopharmacol. 2018, 59, 354-360. [CrossRef]

221. Fituch, C.C.; Palkowetz, K.H.; Goldman, A.S.; Schanler, R.J. Concentrations of IL-10 in preterm human milk and in milk from mothers of infants with necrotizing enterocolitis. Acta Paediatr. 2004, 93, 1496-1500. [CrossRef]

222. Chatterton, D.E.; Nguyen, D.N.; Bering, S.B.; Sangild, P.T. Anti-inflammatory mechanisms of bioactive milk proteins in the intestine of newborns. Int. J. Biochem. Cell Biol. 2013, 45, 1730-1747. [CrossRef]

223. Shiou, S.R.; Yu, Y.; Guo, Y.; Westerhoff, M.; Lu, L.; Petrof, E.O.; Sun, J.; Claud, E.C. Oral administration of transforming growth factor- $\beta 1$ (TGF- $\beta 1$ ) protects the immature gut from injury via Smad protein-dependent suppression of epithelial nuclear factor кB (NF-кB) signaling and proinflammatory cytokine production. J. Biol. Chem. 2013, 288, 34757-34766. [CrossRef]

224. Patel, A.L.; Kim, J.H. Human milk and necrotizing enterocolitis. Semin. Pediatr. Surg. 2018, 27, 34-38. [CrossRef]

225. Ares, G.J.; McElroy, S.J.; Hunter, C.J. The science and necessity of using animal models in the study of necrotizing enterocolitis. Semin. Pediatr. Surg. 2018, 27, 29-33. [CrossRef]

226. Siggers, R.H.; Siggers, J.; Thymann, T.; Boye, M.; Sangild, P.T. Nutritional modulation of the gut microbiota and immune system in preterm neonates susceptible to necrotizing enterocolitis. J. Nutr. Biochem. 2011, 22, 511-521. [CrossRef]

227. Maffei, D.; Schanler, R.J. Human milk is the feeding strategy to prevent necrotizing enterocolitis! Semin. Perinatol. 2017, 41, 36-40. [CrossRef]

228. Ou, J.; Courtney, C.M.; Steinberger, A.E.; Tecos, M.E.; Warner, B.W. Nutrition in necrotizing enterocolitis and following intestinal resection. Nutrients 2020, 12, 520. [CrossRef]

229. Xu, A.T.; Lu, J.T.; Ran, Z.H.; Zheng, Q. Exosome in intestinal mucosal immunity. J. Gastroenterol. Hepatol. 2016, 31, 1694-1699. [CrossRef]

230. Chen, W.; Wang, X.; Yan, X.; Yu, Z.; Zhang, J.; Han, S. The emerging role of exosomes in the pathogenesis, prognosis and treatment of necrotizing enterocolitis. Am. J. Transl. Res. 2020, 12, 7020-7033.

231. Martin, C.; Patel, M.; Williams, S.; Arora, H.; Brawner, K.; Sims, B. Human breast milk-derived exosomes attenuate cell death in intestinal epithelial cells. Innate Immun. 2018, 24, 278-284. [CrossRef] [PubMed]

232. Pisano, C.; Galley, J.; Elbahrawy, M.; Wang, Y.; Farrell, A.; Brigstock, D.; Besner, G.E. Human breast milk-derived extracellular vesicles in the protection against experimental necrotizing enterocolitis. J. Pediatr. Surg. 2020, 55, 54-58. [CrossRef] [PubMed]

233. Wang, X.; Yan, X.; Zhang, L.; Cai, J.; Zhou, Y.; Liu, H.; Hu, Y.; Chen, W.; Xu, S.; Liu, P.; et al. Identification and peptidomic profiling of exosomes in preterm human milk: Insights into necrotizing enterocolitis prevention. Mol. Nutr. Food Res. 2019, 63, e1801247. [CrossRef] [PubMed] 
234. Wu, D.; Kittana, H.; Shu, J.; Kachman, S.D.; Cui, J.; Ramer-Tait, A.E.; Zempleni, J. Dietary depletion of milk exosomes and their microRNA cargos elicits a depletion of miR-200a-3p and elevated intestinal inflammation and chemokine (C-X-C motif) ligand 9 expression in Mdr1a-/- mice. Curr. Dev. Nutr. 2019, 3, nzz122.

235. Stremmel, W.; Weiskirchen, R.; Melnik, B.C. Milk exosomes prevent intestinal inflammation in a genetic mouse model of ulcerative colitis: A pilot experiment. Inflamm. Intest. Dis. 2020, 5, 117-123. [CrossRef]

236. Jiang, K.; Yang, J.; Yang, C.; Zhang, T.; Shaukat, A.; Yang, X.; Dai, A.; Wu, H.; Deng, G. miR-148a suppresses inflammation in lipopolysaccharide-induced endometritis. J. Cell. Mol. Med. 2020, 24, 405-417. [CrossRef]

237. Zhu, Y.; Gu, L.; Li, Y.; Lin, X.; Shen, H.; Cui, K.; Chen, L.; Zhou, F.; Zhao, Q.; Zhang, J.; et al. miR-148a inhibits colitis and colitis-associated tumorigenesis in mice. Cell Death Differ. 2017, 24, 2199-2209. [CrossRef]

238. Ashizawa, M.; Okayama, H.; Ishigame, T.; Thar Min, A.K.; Saito, K.; Ujiie, D.; Murakami, Y.; Kikuchi, T.; Nakayama, Y.; Noda, M.; et al. MiRNA-148a-3p regulates immunosuppression in DNA mismatch repair-deficient colorectal cancer by targeting PD-L1. Mol. Cancer Res. 2019, 17, 1403-1413.

239. Murakami, M.; Narazaki, M.; Hibi, M.; Yawata, H.; Yasukawa, K.; Hamaguchi, M.; Taga, T.; Kishimoto, T. Critical cytoplasmic region of the interleukin 6 signal transducer gp130 is conserved in the cytokine receptor family. Proc. Natl. Acad. Sci. USA 1991, 88, 11349-11353. [CrossRef]

240. Taga, T.; Kishimoto, T. Gp130 and the interleukin-6 family of cytokines. Annu. Rev. Immunol. 1997, 15, 797-819. [CrossRef]

241. Garbers, C.; Aparicio-Siegmund, S.; Rose-John, S. The IL-6/gp130/STAT3 signaling axis: Recent advances towards specific inhibition. Curr. Opin. Immunol. 2015, 34, 75-82. [CrossRef]

242. Uciechowski, P.; Dempke, W.C.M. Interleukin-6: A masterplayer in the cytokine network. Oncology 2020, 98, 131-137. [CrossRef]

243. Zschiedrich, I.; Hardeland, U.; Krones-Herzig, A.; Berriel Diaz, M.; Vegiopoulos, A.; Müggenburg, J.; Sombroek, D.; Hofmann, T.G.; Zawatzky, R.; Yu, X.; et al. Coactivator function of RIP140 for NFkappaB/RelA-dependent cytokine gene expression. Blood 2008, 112, 264-276. [CrossRef]

244. Hu, F.; Wang, M.; Xiao, T.; Yin, B.; He, L.; Meng, W.; Dong, M.; Liu, F. miR-30 promotes thermogenesis and the development of beige fat by targeting RIP140. Diabetes 2015, 64, 2056-2068. [CrossRef]

245. Melnik, B.C.; John, S.M.; Carrera-Bastos, P.; Cordain, L. The impact of cow's milk-mediated mTORC1-signaling in the initiation and progression of prostate cancer. Nutr. Metab. 2012, 9, 74. [CrossRef]

246. Song, Y.; Chavarro, J.E.; Cao, Y.; Qiu, W.; Mucci, L.; Sesso, H.D.; Stampfer, M.J.; Giovannucci, E.; Pollak, M.; Liu, S.; et al. Whole milk intake is associated with prostate cancer-specific mortality among U.S. male physicians. J. Nutr. 2013, 143, 189-196. [CrossRef]

247. Lu, W.; Chen, H.; Niu, Y.; Wu, H.; Xia, D.; Wu, Y. Dairy products intake and cancer mortality risk: A meta-analysis of 11 population-based cohort studies. Nutr. J. 2016, 15, 91. [CrossRef]

248. Melnik, B.C.; Schmitz, G. Exosomes of pasteurized milk: Potential pathogens of Western diseases. J. Transl. Med. 2019, 17, 3. [CrossRef]

249. Aune, D.; Lau, R.; Chan, D.S.M.; Vieira, R.; Greenwood, D.C.; Kampman, E.; Norat, T. Dairy products and colorectal cancer risk: A systematic review and meta-analysis of cohort studies. Ann. Oncol. 2012, 23, 37-45. [CrossRef]

250. Ralston, R.A.; Truby, H.; Palermo, C.E.; Walker, K.Z. Colorectal cancer and nonfermented milk, solid cheese, and fermented milk consumption: A systematic review and meta-analysis of prospective studies. Crit. Rev. Food Sci. Nutr. 2014, 54, 1167-1179. [CrossRef]

251. Vieira, A.R.; Abar, L.; Chan, D.S.M.; Vingeliene, S.; Polemiti, E.; Stevens, C.; Greenwood, D.; Norat, T. Foods and beverages and colorectal cancer risk: A systematic review and meta-analysis of cohort studies, an update of the evidence of the WCRF-AICR Continuous Update Project. Ann. Oncol. 2017, 28, 1788-1802. [CrossRef] [PubMed]

252. Dybos, S.A.; Flatberg, A.; Halgunset, J.; Viset, T.; Rolfseng, T.; Kvam, S.; Skogseth, H. Increased levels of serum miR-148a-3p are associated with prostate cancer. APMIS 2018, 126, 722-731. [CrossRef] [PubMed]

253. Tsai, H.L.; Yang, I.P.; Huang, C.W.; Ma, C.J.; Kuo, C.H.; Lu, C.Y.; Juo, S.H.; Wang, J.Y. Clinical significance of microRNA-148a in patients with early relapse of stage II stage and III colorectal cancer after curative resection. Transl. Res. 2013, 162, 258-268. [CrossRef] [PubMed]

254. Baltruskeviciene, E.; Schveigert, D.; Stankevicius, V.; Mickys, U.; Zvirblis, T.; Bublevic, J.; Suziedelis, K.; Aleknavicius, E. Downregulation of miRNA-148a and miRNA-625-3p in colorectal cancer is associated with tumor budding. BMC Cancer 2017, 17,607. [CrossRef] [PubMed]

255. Eilebrecht, S.; Hotz-Wagenblatt, A.; Sarachaga, V.; Burk, A.; Falida, K.; Chakraborty, D.; Nikitina, E.; Tessmer, C.; Whitley, C.; Sauerland, C.; et al. Expression and replication of virus-like circular DNA in human cells. Sci. Rep. 2018, 8, 2851. [CrossRef] [PubMed]

256. Bund, T.; Nikitina, E.; Chakraborty, D.; Ernst, C.; Gunst, K.; Boneva, B.; Tessmer, C.; Volk, N.; Brobeil, A.; Weber, A.; et al. Analysis of chronic inflammatory lesions of the colon for BMMF Rep antigen expression and CD68 macrophage interactions. Proc. Natl. Acad. Sci. USA 2021, 118, e2025830118. [CrossRef] [PubMed]

257. Gitto, E.; Marseglia, L.; Manti, S.; D’Angelo, G.; Barberi, I.; Salpietro, C.; Reiter, R.J. Protective role of melatonin in neonatal diseases. Oxid. Med. Cell. Longev. 2013, 2013, 980374. [CrossRef]

258. D'Angelo, G.; Chimenz, R.; Reiter, R.J.; Gitto, E. Use of melatonin in oxidative stress related neonatal diseases. Antioxidants 2020, 9, 477. [CrossRef] 
259. Esteban-Zubero, E.; López-Pingarrón, L.; Alatorre-Jiménez, M.A.; Ochoa-Moneo, P.; Buisac-Ramón, C.; Rivas-Jiménez, M.; Castán-Ruiz, S.; Antoñanzas-Lombarte, Á.; Tan, D.X.; García, J.J.; et al. Melatonin's role as a co-adjuvant treatment in colonic diseases: A review. Life Sci. 2017, 170, 72-81. [CrossRef]

260. Kim, J.M.; Lee, S.Y.; Lee, J.Y. Melatonin for the prevention of fetal injury associated with intrauterine inflammation. Am. J. Reprod. Immunol. 2021, e13402. [CrossRef]

261. Qin, Y.; Shi, W.; Zhuang, J.; Liu, Y.; Tang, L.; Bu, J.; Sun, J.; Bei, F. Variations in melatonin levels in preterm and term human breast milk during the first month after delivery. Sci. Rep. 2019, 9, 17984. [CrossRef]

262. Guven, A.; Uysal, B.; Gundogdu, G.; Oztas, E.; Ozturk, H.; Korkmaz, A. Melatonin ameliorates necrotizing enterocolitis in a neonatal rat model. J. Pediatr. Surg. 2011, 46, 2101-2107. [CrossRef]

263. Ma, F.; Hao, H.; Gao, X.; Cai, Y.; Zhou, J.; Liang, P.; Lv, J.; He, Q.; Shi, C.; Hu, D.; et al. Melatonin ameliorates necrotizing enterocolitis by preventing Th17/Treg imbalance through activation of the AMPK/SIRT1 pathway. Theranostics 2020, 10, 7730-7746. [CrossRef]

264. Lacerda, J.Z.; Ferreira, L.C.; Lopes, B.C.; Aristizábal-Pachón, A.F.; Bajgelman, M.C.; Borin, T.F.; Zuccari, D.A.P.C. Therapeutic potential of melatonin in the regulation of miR-148a-3p and angiogenic factors in breast cancer. MicroRNA 2019, 8, $237-247$. [CrossRef]

265. Muroya, S.; Hagi, T.; Kimura, A.; Aso, H.; Matsuzaki, M.; Nomura, M. Lactogenic hormones alter cellular and extracellular microRNA expression in bovine mammary epithelial cell culture. J. Anim. Sci. Biotechnol. 2016, 7, 8. [CrossRef]

266. Takeda, S.; Kuwabara, Y.; Mizuno, M. Concentrations and origin of oxytocin in breast milk. Endocrinol. Jpn. 1986, 33, 821-826. [CrossRef]

267. Klein, B.Y.; Tamir, H.; Ludwig, R.J.; Glickstein, S.B.; Welch, M.G.; Anwar, M. Colostrum oxytocin modulates cellular stress response, inflammation, and autophagy markers in newborn rat gut villi. Biochem. Biophys. Res. Commun. 2017, 487, 47-53. [CrossRef]

268. Gross Margolis, K.; Vittorio, J.; Talavera, M.; Gluck, K.; Li, Z.; Iuga, A.; Stevanovic, K.; Saurman, V.; Israelyan, N.; Welch, M.G.; et al. Enteric serotonin and oxytocin: Endogenous regulation of severity in a murine model of necrotizing enterocolitis. Am. J. Physiol. Gastrointest. Liver Physiol. 2017, 313, G386-G398. [CrossRef]

269. Kosloske, A.M.; Ball, W.S., Jr.; Umland, E.; Skipper, B. Clostridial necrotizing enterocolitis. J. Pediatr. Surg. 1985, $20,155-159$. [CrossRef]

270. Schönherr-Hellec, S.; Aires, J. Clostridia and necrotizing enterocolitis in preterm neonates. Anaerobe 2019, 58, 6-12. [CrossRef]

271. Støy, A.C.; Mølbak, L.; Delègue, C.L.; Thymann, T.; Sangild, P.T.; Heegaard, P.M.; Manurung, S.; Skovgaard, K. Necrotizing enterocolitis in preterm pigs is associated with increased density of intestinal mucosa-associated bacteria including Clostridium perfringens. Neonatology 2015, 108, 188-195. [CrossRef] [PubMed]

272. Shi, H.; Huang, X.; Yan, Z.; Yang, Q.; Wang, P.; Li, S.; Sun, W.; Gun, S. Effect of Clostridium perfringens type C on TLR4/MyD88/NF-kB signaling pathway in piglet small intestines. Microb. Pathog. 2019, 135, 103567. [CrossRef] [PubMed]

273. Verstrepen, L.; Verhelst, K.; van Loo, G.; Carpentier, I.; Ley, S.C.; Beyaert, R. Expression, biological activities and mechanisms of action of A20 (TNFAIP3). Biochem. Pharmacol. 2010, 80, 2009-2020. [CrossRef] [PubMed]

274. Shembade, N.; Harhaj, E.W. Regulation of NF-кB signaling by the A20 deubiquitinase. Cell. Mol. Immunol. 2012, 9, 123-130. [CrossRef]

275. Hammer, G.E.; Turer, E.E.; Taylor, K.E.; Fang, C.J.; Advincula, R.; Oshima, S.; Barrera, J.; Huang, E.J.; Hou, B.; Malynn, B.A.; et al. Expression of A20 by dendritic cells preserves immune homeostasis and prevents colitis and spondyloarthritis. Nat. Immunol. 2011, 12, 1184-1193. [CrossRef]

276. Skotland, T.; Hessvik, N.P.; Sandvig, K.; Llorente, A. Exosomal lipid composition and the role of ether lipids and phosphoinositides in exosome biology. J. Lipid Res. 2019, 60, 9-18. [CrossRef]

277. Chen, W.; Chen, X.; Qian, Y.; Wang, X.; Zhou, Y.; Yan, X.; Yu, B.; Yao, S.; Yu, Z.; Zhu, J.; et al. Lipidomic profiling of human milk derived exosomes and their emerging Roles in the prevention of necrotizing enterocolitis. Mol. Nutr. Food Res. 2021, e2000845. [CrossRef]

278. Yu, H.; Dilbaz, S.; Coßmann, J.; Hoang, A.C.; Diedrich, V.; Herwig, A.; Harauma, A.; Hoshi, Y.; Moriguchi, T.; Landgraf, K.; et al. Breast milk alkylglycerols sustain beige adipocytes through adipose tissue macrophages. J. Clin. Invest. 2019, 129, 2485-2499. [CrossRef]

279. Phuyal, S.; Skotland, T.; Hessvik, N.P.; Simolin, H.; Øverbye, A.; Brech, A.; Parton, R.G.; Ekroos, K.; Sandvig, K.; Llorente, A. The ether lipid precursor hexadecylglycerol stimulates the release and changes the composition of exosomes derived from PC-3 cells. J. Biol. Chem. 2015, 290, 4225-4237. [CrossRef]

280. Wallner, S.; Grandl, M.; Konovalova, T.; Sigrüner, A.; Kopf, T.; Peer, M.; Orsó, E.; Liebisch, G.; Schmitz, G. Monocyte to macrophage differentiation goes along with modulation of the plasmalogen pattern through transcriptional regulation. PLoS ONE 2014, 9, e94102. [CrossRef]

281. Wallner, S.; Orsó, E.; Grandl, M.; Konovalova, T.; Liebisch, G.; Schmitz, G. Phosphatidylcholine and phosphatidylethanolamine plasmalogens in lipid loaded human macrophages. PLoS ONE 2018, 13, e0205706. [CrossRef]

282. Zhao, H.; Shang, Q.; Pan, Z.; Bai, Y.; Li, Z.; Zhang, H.; Zhang, Q.; Guo, C.; Zhang, L.; Wang, Q. Exosomes from adipose-derived stem cells attenuate adipose inflammation and obesity through polarizing M2 macrophages and beiging in white adipose tissue. Diabetes 2018, 67, 235-247. [CrossRef] 
283. Ikeda, K.; Maretich, P.; Kajimura, S. The common and distinct features of brown and beige adipocytes. Trends Endocrinol. Metab. 2018, 29, 191-200. [CrossRef]

284. Rui, L. Brown and beige adipose tissues in health and disease. Compr. Physiol. 2017, 7, 1281-1306.

285. Maghraby, M.K.; Li, B.; Chi, L.; Ling, C.; Benmoussa, A.; Provost, P.; Postmus, A.C.; Abdi, A.; Pierro, A.; Bourdon, C.; et al. Extracellular vesicles isolated from milk can improve gut barrier dysfunction induced by malnutrition. Sci. Rep. 2021, 11, 7635 . [CrossRef]

286. Auerbach, A.; Vyas, G.; Li, A.; Halushka, M.; Witwer, K. Uptake of dietary milk miRNAs by adult humans: A validation study. F1000Research 2016, 5, 721. [CrossRef]

287. Lin, D.; Chen, T.; Xie, M.; Li, M.; Zeng, B.; Sun, R.; Zhu, Y.; Ye, D.; Wu, J.; Sun, J.; et al. Oral administration of bovine and porcine milk exosome alter miRNAs profiles in piglet serum. Sci. Rep. 2020, 10, 6983.

288. Baier, S.R.; Nguyen, C.; Xie, F.; Wood, J.R.; Zempleni, J. MicroRNAs are absorbed in biologically meaningful amounts from nutritionally relevant doses of cow milk and affect gene expression in peripheral blood mononuclear cells, HEK-293 kidney cell cultures, and mouse livers. J. Nutr. 2014, 144, 1495-1500. [CrossRef]

289. Wang, L.; Sadri, M.; Giraud, D.; Zempleni, J. RNase H2-dependent polymerase chain reaction and elimination of confounders in sample collection, storage, and analysis atrengthen evidence that microRNAs in bovine milk are bioavailable in humans. J. Nutr. 2018, 148, 153-159. [CrossRef]

290. Aqil, F.; Munagala, R.; Jeyabalan, J.; Agrawal, A.K.; Kyakulaga, A.H.; Wilcher, S.A.; Gupta, R.C. Milk exosomes-Natural nanoparticles for siRNA delivery. Cancer Lett. 2019, 449, 186-195. [CrossRef]

291. Agrawal, A.K.; Aqil, F.; Jeyabalan, J.; Spencer, W.A.; Beck, J.; Gachuki, B.W.; Alhakeem, S.S.; Oben, K.; Munagala, R.; Bondada, S.; et al. Milk-derived exosomes for oral delivery of paclitaxel. Nanomedicine 2017, 13, 1627-1636. [CrossRef] [PubMed]

292. Munagala, R.; Aqil, F.; Jeyabalan, J.; Gupta, R.C. Bovine milk-derived exosomes for drug delivery. Cancer Lett. 2016, 371, 48-61. [CrossRef] [PubMed]

293. Betker, J.L.; Angle, B.M.; Graner, M.W.; Anchordoquy, T.J. The potential of exosomes from cow milk for oral delivery. J. Pharm. Sci. 2019, 108, 1496-1505. [CrossRef] [PubMed]

294. Sedykh, S.; Kuleshova, A.; Nevinsky, G. Milk exosomes: Perspective agents for anticancer drug delivery. Int. J. Mol. Sci. 2020, 21, 6646. [CrossRef]

295. Askenase, P.W. Ancient evolutionary origin and properties of universally produced natural exosomes contribute to their therapeutic superiority compared to artificial nanoparticles. Int. J. Mol. Sci. 2021, 22, 1429. [CrossRef]

296. Del Pozo-Acebo, L.; Hazas, M.L.L.; Tomé-Carneiro, J.; Gil-Cabrerizo, P.; San-Cristobal, R.; Busto, R.; García-Ruiz, A.; Dávalos, A. Bovine milk-derived exosomes as a drug delivery vehicle for miRNA-based therapy. Int. J. Mol. Sci. 2021, 22, 1105. [CrossRef]

297. Zempleni, J. Milk exosomes: Beyond dietary microRNAs. Genes Nutr. 2017, 12, 12. [CrossRef]

298. Simeoni, U.; Yzydorczyk, C.; Siddeek, B.; Benahmed, M. Epigenetics and neonatal nutrition. Early Hum. Dev. 2014, 90 (Suppl. S2), S23-S24. [CrossRef]

299. Reynolds, C.M.; Gray, C.; Li, M.; Segovia, S.A.; Vickers, M.H. Early life nutrition and energy balance disorders in offspring in later life. Nutrients 2015, 7, 8090-8111. [CrossRef]

300. Canani, R.B.; Costanzo, M.D.; Leone, L.; Bedogni, G.; Brambilla, P.; Cianfarani, S.; Nobili, V.; Pietrobelli, A.; Agostoni, C. Epigenetic mechanisms elicited by nutrition in early life. Nutr. Res. Rev. 2011, 24, 198-205. [CrossRef]

301. Marousez, L.; Lesage, J.; Eberlé, D. Epigenetics: Linking early postnatal nutrition to obesity programming? Nutrients 2019, 11, 2966. [CrossRef]

302. Sosa-Castillo, E.; Rodríguez-Cruz, M.; Moltó-Puigmartí, C. Genomics of lactation: Role of nutrigenomics and nutrigenetics in the fatty acid composition of human milk. Br. J. Nutr. 2017, 118, 161-168. [CrossRef]

303. Golan, Y.; Assaraf, Y.G. Genetic and physiological factors affecting human milk production and composition. Nutrients 2020, 12, 1500. [CrossRef]

304. Hermann, A.; Goyal, R.; Jeltsch, A. The Dnmt1 DNA-(cytosine-C5)-methyltransferase methylates DNA processively with high preference for hemimethylated target sites. J. Biol. Chem. 2004, 279, 48350-48359. [CrossRef]

305. Li, E.; Zhang, Y. DNA methylation in mammals. Cold Spring Harb. Perspect. Biol. 2014, 6, a019133. [CrossRef]

306. Güngör, D.; Nadaud, P.; LaPergola, C.C.; Dreibelbis, C.; Wong, Y.P.; Terry, N.; Abrams, S.A.; Beker, L.; Jacobovits, T.; Järvinen, K.M.; et al. Infant milk-feeding practices and food allergies, allergic rhinitis, atopic dermatitis, and asthma throughout the life span: A systematic review. Am. J. Clin. Nutr. 2019, 109 (Suppl. S7), 772S-799S. [CrossRef]

307. Bion, V.; Lockett, G.A.; Soto-Ramírez, N.; Zhang, H.; Venter, C.; Karmaus, W.; Holloway, J.W.; Arshad, S.H. Evaluating the efficacy of breastfeeding guidelines on long-term outcomes for allergic disease. Allergy 2016, 71, 661-760. [CrossRef]

308. Greer, F.R.; Sicherer, S.H.; Burks, A.W.; Committee on Nutrition; Section on Allergy and Immunology. The effects of early nutritional interventions on the development of atopic disease in infants and children: The role of maternal dietary restriction, breastfeeding, hydrolyzed formulas, and timing of introduction of allergenic complementary foods. Pediatrics 2019, 143, e20190281. [CrossRef]

309. Sitarik, A.R.; Kasmikha, N.S.; Kim, H.; Wegienka, G.; Havstad, S.; Ownby, D.; Zoratti, E.; Johnson, C.C. Breast-feeding and delivery mode modify the association between maternal atopy and childhood allergic outcomes. J. Allergy Clin. Immunol. 2018, 142, 2002-2004. [CrossRef] 
310. Torregrosa Paredes, P.; Gutzeit, C.; Johansson, S.; Admyre, C.; Stenius, F.; Alm, J.; Scheynius, A.; Gabrielsson, S. Differences in exosome populations in human breast milk in relation to allergic sensitization and lifestyle. Allergy 2014, 69, 463-471. [CrossRef]

311. Simpson, M.R.; Brede, G.; Johansen, J.; Johnsen, R.; Storrø, O.; Sætrom, P.; Øien, T. Human breast milk miRNA, maternal probiotic supplementation and atopic dermatitis in offspring. PLoS ONE 2015, 10, e0143496. [CrossRef] [PubMed]

312. Shelke, G.V.; Yin, Y.; Jang, S.C.; Lässer, C.; Wennmalm, S.; Hoffmann, H.J.; Li, L.; Gho, Y.S.; Nilsson, J.A.; Lötvall, J. Endosomal signalling via exosome surface TGF $\beta-1$. J. Extracell. Vesicles 2019, 8, 1650458. [CrossRef] [PubMed]

313. Chen, W.; Jin, W.; Hardegen, N.; Lei, K.J.; Li, L.; Marinos, N.; McGrady, G.; Wahl, S.M. Conversion of peripheral CD4+CD25naive $\mathrm{T}$ cells to CD4+CD25+ regulatory T cells by TGF-beta induction of transcription factor Foxp3. J. Exp. Med. 2003, 198, 1875-1886. [CrossRef] [PubMed]

314. Takimoto, T.; Wakabayashi, Y.; Sekiya, T.; Inoue, N.; Morita, R.; Ichiyama, K.; Takahashi, R.; Asakawa, M.; Muto, G.; Mori, T.; et al. Smad2 and Smad3 are redundantly essential for the TGF-beta-mediated regulation of regulatory T plasticity and Th1 development. J. Immunol. 2010, 185, 842-855.

315. Ito, M.; Iizuka-Koga, M.; Ando, M.; Yoshimura, A. Development and functional modulation of regulatory T cells by transcription factors and epigenetics. Cornea 2018, 37 (Suppl. S1), S42-S49. [CrossRef]

316. Liao, H.; Peng, X.; Gan, L.; Feng, J.; Gao, Y.; Yang, S.; Hu, X.; Zhang, L.; Yin, Y.; Wang, H.; et al. Protective regulatory T cell immune response induced by intranasal immunization with the live-attenuated pneumococcal vaccine SPY1 via the transforming growth factor- $\beta 1-S m a d 2 / 3$ pathway. Front. Immunol. 2018, 9, 1754. [CrossRef]

317. Nazimek, K.; Bryniarski, K.; Askenase, P.W. Functions of exosomes and microbial extracellular vesicles in allergy and contact and delayed-type hypersensitivity. Int. Arch. Allergy Immunol. 2016, 171, 1-26. [CrossRef]

318. Pegtel, D.M.; Gould, S.J. Exosomes. Annu. Rev. Biochem. 2019, 88, 487-514. [CrossRef]

319. Le Doare, K.; Holder, B.; Bassett, A.; Pannaraj, P.S. Mother's milk: A purposeful contribution to the development of the infant microbiota and immunity. Front. Immunol. 2018, 9, 361.

320. Skogberg, G.; Telemo, E.; Ekwall, O. Exosomes in the thymus: Antigen transfer and vesicles. Front. Immunol. 2015, 6, 366. [CrossRef]

321. Lundberg, V.; Berglund, M.; Skogberg, G.; Lindgren, S.; Lundqvist, C.; Gudmundsdottir, J.; Thörn, K.; Telemo, E.; Ekwall, O. Thymic exosomes promote the final maturation of thymocytes. Sci. Rep. 2016, 6, 36479. [CrossRef]

322. Wang, G.J.; Liu, Y.; Qin, A.; Shah, S.V.; Deng, Z.B.; Xiang, X.; Cheng, Z.; Liu, C.; Wang, J.; Zhang, L.; et al. Thymus exosomes-like particles induce regulatory T cells. J. Immunol. 2008, 181, 5242-5248. [CrossRef]

323. Peroni, D.G.; Piacentini, G.L.; Bodini, A.; Pigozzi, R.; Boner, A.L. Transforming growth factor-beta is elevated in unpasteurized cow's milk. Pediatr. Allergy Immunol. 2009, 20, 42-44.

324. Jones, J.G. Hepatic glucose and lipid metabolism. Diabetologia 2016, 59, 1098-1103. [CrossRef]

325. Kubes, P.; Jenne, C. Immune responses in the liver. Annu. Rev. Immunol. 2018, 36, 247-277. [CrossRef]

326. Pyzik, M.; Rath, T.; Kuo, T.T.; Win, S.; Baker, K.; Hubbard, J.J.; Grenha, R.; Gandhi, A.; Krämer, T.D.; Mezo, A.R.; et al. Hepatic FcRn regulates albumin homeostasis and susceptibility to liver injury. Proc. Natl. Acad. Sci. USA 2017, 114, E2862-E2871. [CrossRef]

327. Latvala, S.; Jacobsen, B.; Otteneder, M.B.; Herrmann, A.; Kronenberg, S. Distribution of FcRn across species and tissues. J. Histochem. Cytochem. 2017, 65, 321-333. [CrossRef]

328. Fan, Y.Y.; Farrokhi, V.; Caiazzo, T.; Wang, M.; O’Hara, D.M.; Neubert, H. Human FcRn tissue expression profile and half-life in PBMCs. Biomolecules 2019, 9, 373. [CrossRef]

329. Devhare, P.B.; Sasaki, R.; Shrivastava, S.; Di Bisceglie, A.M.; Ray, R.; Ray, R.B. Exosome-mediated intercellular communication between hepatitis C virus-infected hepatocytes and hepatic stellate cells. J. Virol. 2017, 91, e02225-e02316. [CrossRef]

330. Weiskirchen, R.; Tacke, F. Cellular and molecular functions of hepatic stellate cells in inflammatory responses and liver immunology. Hepatobiliary Surg. Nutr. 2014, 3, 344-363.

331. Li, L.; Hu, W.; Liu, K.; Zhang, D.; Liu, M.; Li, X.; Wang, H. miR-148a/LDLR mediates hypercholesterolemia induced by prenatal dexamethasone exposure in male offspring rats. Toxicol. Appl. Pharmacol. 2020, 395, 114979. [CrossRef]

332. Mersey, B.D.; Jin, P.; Danner, D.J. Human microRNA (miR29b) expression controls the amount of branched chain alpha-ketoacid dehydrogenase complex in a cell. Hum. Mol. Genet. 2005, 14, 3371-3377. [CrossRef]

333. Kimball, S.R.; Jefferson, L.S. Regulation of protein synthesis by branched-chain amino acids. Curr. Opin. Clin. Nutr. Metab. Care 2001, 4, 39-43. [CrossRef]

334. Suryawan, A.; Davis, T.A. Regulation of protein synthesis by amino acids in muscle of neonates. Front. Biosci. 2011, 16, 1445-1460. [CrossRef]

335. Ijichi, C.; Matsumura, T.; Tsuji, T.; Eto, Y. Branched-chain amino acids promote albumin synthesis in rat primary hepatocytes through the mTOR signal transduction system. Biochem. Biophys. Res. Commun. 2003, 303, 59-64. [CrossRef]

336. Horta, B.L.; Loret de Mola, C.; Victora, C.G. Breastfeeding and intelligence: A systematic review and meta-analysis. Acta Paediatr. 2015, 104, 14-19. [CrossRef]

337. Koh, K. Maternal breastfeeding and children's cognitive development. Soc. Sci. Med. 2017, 187, 101-108. [CrossRef]

338. Keim, S.A.; Sullivan, J.A.; Sheppard, K.; Smith, K.; Ingol, T.; Boone, K.M.; Malloy-McCoy, A.; Oza-Frank, R. Feeding infants at the breast or feeding expressed human milk: Long-term cognitive, executive function, and eating behavior outcomes at age 6 years. J. Pediatr. 2021. [CrossRef] 
339. Kramer, M.S.; Aboud, F.; Mironova, E.; Vanilovich, I.; Platt, R.W.; Matush, L.; Igumnov, S.; Fombonne, E.; Bogdanovich, N.; Ducruet, T.; et al. Promotion of Breastfeeding Intervention Trial (PROBIT) Study Group. Breastfeeding and child cognitive development: New evidence from a large randomized trial. Arch. Gen. Psychiatry 2008, 65, 578-584.

340. Horta, B.L.; de Sousa, B.A.; de Mola, C.L. Breastfeeding and neurodevelopmental outcomes. Curr. Opin. Clin. Nutr. Metab. Care 2018, 21, 174-178. [CrossRef]

341. Chen, C.C.; Liu, L.; Ma, F.; Wong, C.W.; Guo, X.E.; Chacko, J.V.; Farhoodi, H.P.; Zhang, S.X.; Zimak, J.; Ségaliny, A.; et al. Elucidation of exosome migration across the blood-brain barrier model in vitro. Cell. Mol. Bioeng. 2016, 9, 509-529. [CrossRef] [PubMed]

342. Patel, M.M.; Patel, B.M. Crossing the blood-brain barrier: Recent advances in drug delivery to the brain. CNS Drugs 2017, 31, 109-133. [CrossRef] [PubMed]

343. Jakubec, M.; Maple-Grødem, J.; Akbari, S.; Nesse, S.; Halskau, Ø.; Mork-Jansson, A.E. Plasma-derived exosome-like vesicles are enriched in lyso-phospholipids and pass the blood-brain barrier. PLoS ONE 2020, 15, e0232442. [CrossRef] [PubMed]

344. Saint-Pol, J.; Gosselet, F.; Duban-Deweer, S.; Pottiez, G.; Karamanos, Y. Targeting and crossing the blood-brain barrier with extracellular vesicles. Cells 2020, 9, 851. [CrossRef] [PubMed]

345. Bouret, S.G. Nutritional programming of hypothalamic development: Critical periods and windows of opportunity. Int. J. Obes. Suppl. 2012, 2 (Suppl. S2), S19-S24. [CrossRef]

346. Jakowec, M.W.; Donaldson, D.M.; Barba, J.; Petzinger, G.M. Postnatal expression of alpha-synuclein protein in the rodent substantia nigra and striatum. Dev. Neurosci. 2001, 23, 91-99. [CrossRef]

347. Yavich, L.; Tanila, H.; Vepsäläinen, S.; Jäkälä, P. Role of alpha-synuclein in presynaptic dopamine recruitment. J. Neurosci. 2004, 24, 11165-11170. [CrossRef]

348. Burré, J. The synaptic function of $\alpha$-synuclein. J. Parkinsons Dis. 2015, 5, 699-713. [CrossRef]

349. Burré, J.; Sharma, M.; Südhof, T.C. Cell biology and pathophysiology of $\alpha$-synuclein. Cold Spring Harb. Perspect. Med. 2018, 8, a024091. [CrossRef]

350. Sulzer, D.; Edwards, R.H. The physiological role of $\alpha$-synuclein and its relationship to Parkinson's Disease. J. Neurochem. 2019, 150, 475-486. [CrossRef]

351. Westphal, C.H.; Chandra, S.S. Monomeric synucleins generate membrane curvature. J. Biol. Chem. 2013, 288, 1829-1840. [CrossRef]

352. Burré, J.; Sharma, M.; Tsetsenis, T.; Buchman, V.; Etherton, M.R.; Südhof, T.C. Alpha-synuclein promotes SNARE-complex assembly in vivo and in vitro. Science 2010, 329, 1637-1663. [CrossRef]

353. Lou, X.; Kim, J.; Hawk, B.J.; Shin, Y.K. $\alpha$-Synuclein may cross-bridge v-SNARE and acidic phospholipids to facilitate SNAREdependent vesicle docking. Biochem. J. 2017, 474, 2039-2049. [CrossRef]

354. Xiong, Q.Y.; Yu, C.; Zhang, Y.; Ling, L.; Wang, L.; Gao, J.L. Key proteins involved in insulin vesicle exocytosis and secretion. Biomed. Rep. 2017, 6, 134-139. [CrossRef]

355. Varkey, J.; Isas, J.M.; Mizuno, N.; Jensen, M.B.; Bhatia, V.K.; Jao, C.C.; Petrlova, J.; Voss, J.C.; Stamou, D.G.; Steven, A.C.; et al. Membrane curvature induction and tubulation are common features of synucleins and apolipoproteins. J. Biol. Chem. 2010, 285, 32486-32493. [CrossRef]

356. Mor, D.E.; Tsika, E.; Mazzulli, J.R.; Gould, N.S.; Kim, H.; Daniels, M.J.; Doshi, S.; Gupta, P.; Grossman, J.L.; Tan, V.X.; et al. Dopamine induces soluble $\alpha$-synuclein oligomers and nigrostriatal degeneration. Nat. Neurosci. 2017, 20, 1560-1568. [CrossRef]

357. Zhang, J.; Li, X.; Li, J.D. The roles of post-translational modifications on $\alpha$-synuclein in the pathogenesis of Parkinson's diseases. Front. Neurosci. 2019, 13, 381. [CrossRef]

358. Xu, J.; Camfield, R.; Gorski, S.M. The interplay between exosomes and autophagy-Partners in crime. J. Cell Sci. 2018, 131, jcs215210. [CrossRef]

359. Matsumoto, L.; Takuma, H.; Tamaoka, A.; Kurisaki, H.; Date, H.; Tsuji, S.; Iwata, A. CpG demethylation enhances alphasynuclein expression and affects the pathogenesis of Parkinson's disease. PLOS ONE 2010, 5, e15522. [CrossRef]

360. Desplats, P.; Spencer, B.; Coffee, E.; Patel, P.; Michael, S.; Patrick, C.; Adame, A.; Rockenstein, E.; Masliah, E. Alpha-synuclein sequesters Dnmt1 from the nucleus: A novel mechanism for epigenetic alterations in Lewy body diseases. J. Biol. Chem. 2011, 286, 9031-9037. [CrossRef]

361. Wang, Y.; Wang, X.; Li, R.; Yang, Z.F.; Wang, Y.Z.; Gong, X.L.; Wang, X.M. A DNA methyltransferase inhibitor, 5-aza-2'deoxycytidine, exacerbates neurotoxicity and upregulates Parkinson's disease-related genes in dopaminergic neurons. CNS Neurosci. Ther. 2013, 19, 183-190. [CrossRef] [PubMed]

362. Jiang, W.; Li, J.; Zhang, Z.; Wang, H.; Wang, Z. Epigenetic upregulation of alpha-synuclein in the rats exposed to methamphetamine. Eur. J. Pharmacol. 2014, 745, 243-248. [CrossRef] [PubMed]

363. Tan, Y.Y.; Wu, L.; Zhao, Z.B.; Wang, Y.; Xiao, Q.; Liu, J.; Wang, G.; Ma, J.F.; Chen, S.D. Methylation of $\alpha$-synuclein and leucine-rich repeat kinase 2 in leukocyte DNA of Parkinson's disease patients. Parkinsonism Relat. Disord. 2014, 20, 308-313. [CrossRef]

364. Muller, T.; Kohlhepp, W. Hypomethylation in Parkinson's disease: An epigenetic drug effect? Mov. Disord. 2016, $31,605$. [CrossRef] [PubMed]

365. Wullner, U.; Kaut, O.; deBoni, L.; Piston, D.; Schmitt, I. DNA methylation in Parkinson's disease. J. Neurochem. 2016, 139 (Suppl. S1), 108-120. [CrossRef] [PubMed] 
366. Guhathakurta, S.; Bok, E.; Evangelista, B.A.; Kim, Y.S. Deregulation of $\alpha$-synuclein in Parkinson's disease: Insight from epigenetic structure and transcriptional regulation of SNCA. Prog. Neurobiol. 2017, 154, 21-36. [CrossRef] [PubMed]

367. Eryilmaz, I.E.; Cecener, G.; Erer, S.; Egeli, U.; Tunca, B.; Zarifoglu, M.; Elibol, B.; Bora Tokcaer, A.; Saka, E.; Demirkiran, M.; et al. Epigenetic approach to early-onset Parkinson's disease: Low methylation status of SNCA and PARK2 promoter regions. Neurol. Res. 2017, 39, 965-972. [CrossRef] [PubMed]

368. Melnik, B.C. Synergistic effects of milk-derived exosomes and galactose on $\alpha$-synuclein pathology in Parkinson's disease and type 2 diabetes mellitus. Int. J. Mol. Sci. 2021, 22, 1059. [CrossRef]

369. Mutai, E.; Zhou, F.; Zempleni, J. Depletion of dietary bovine milk exosomes impairs sensorimotor gating and spatial learning in C57BL/ 6 mice. FASEB J. 2018, 31, S1.

370. Martínez, J.A.; Cordero, P.; Campión, J.; Milagro, F.I. Interplay of early-life nutritional programming on obesity, inflammation and epigenetic outcomes. Proc. Nutr. Soc. 2012, 71, 276-283. [CrossRef]

371. Jermendy, A.; Toschi, E.; Aye, T.; Koh, A.; Aguayo-Mazzucato, C.; Sharma, A.; Weir, G.C.; Sgroi, D.; Bonner-Weir, S. Rat neonatal beta cells lack the specialised metabolic phenotype of mature beta cells. Diabetologia 2011, 54, 594-604. [CrossRef]

372. Finegood, D.T.; Scaglia, L.; Bonner-Weir, S. Dynamics of beta-cell mass in the growing rat pancreas. Estimation with a simple mathematical model. Diabetes 1995, 44, 249-256. [CrossRef]

373. Gregg, B.E.; Moore, P.C.; Demozay, D.; Hall, B.A.; Li, M.; Husain, A.; Wright, A.J.; Atkinson, M.A.; Rhodes, C.J. Formation of a human $\beta$-cell population within pancreatic islets is set early in life. J. Clin. Endocrinol. Metab. 2012, 97, 3197-3206. [CrossRef]

374. Zeng, C.; Mulas, F.; Sui, Y.; Guan, T.; Miller, N.; Tan, Y.; Liu, F.; Jin, W.; Carrano, A.C.; Huising, M.O.; et al. Pseudotemporal ordering of single cells reveals metabolic control of postnatal $\beta$ cell proliferation. Cell Metab. 2017, 25, 1160-1175. [CrossRef]

375. Deng, Z.B.; Poliakov, A.; Hardy, R.W.; Clements, R.; Liu, C.; Liu, Y.; Wang, J.; Xiang, X.; Zhang, S.; Zhuang, X.; et al. Adipose tissue exosome-like vesicles mediate activation of macrophage-induced insulin resistance. Diabetes 2009, 58, 2498-2505. [CrossRef]

376. Jalabert, A.; Vial, G.; Guay, C.; Wiklander, O.P.; Nordin, J.Z.; Aswad, H.; Forterre, A.; Meugnier, E.; Pesenti, S.; Regazzi, R.; et al. Exosome-like vesicles released from lipid-induced insulin-resistant muscles modulate gene expression and proliferation of beta recipient cells in mice. Diabetologia 2016, 59, 1049-1058. [CrossRef]

377. Guay, C.; Regazzi, R. Exosomes as new players in metabolic organ cross-talk. Diabetes Obes. Metab. 2017, 19 (Suppl. S1), 137-146. [CrossRef]

378. Sun, Y.; Shi, H.; Yin, S.; Ji, C.; Zhang, X.; Zhang, B.; Wu, P.; Shi, Y.; Mao, F.; Yan, Y.; et al. Human mesenchymal stem cell derived exosomes alleviate type 2 diabetes mellitus by reversing peripheral insulin resistance and relieving $\beta$-cell destruction. ACS Nano 2018, 12, 7613-7628. [CrossRef]

379. Ge, Q.; Xie, X.X.; Xiao, X.; Li, X. Exosome-like vesicles as new mediators and therapeutic targets for treating insulin resistance and $\beta$-cell mass failure in type 2 diabetes mellitus. J. Diabetes Res. 2019, 2019, 3256060. [CrossRef]

380. Marzan, A.L.; Nedeva, C.; Mathivanan, S. Extracellular vesicles in metabolism and metabolic diseases. Subcell. Biochem. 2021, 97, 393-410.

381. Melnik, B.C. The pathogenic role of persistent milk signaling in mTORC1- and milk- microRNA-driven type 2 diabetes mellitus. Curr. Diabetes Rev. 2015, 11, 46-62. [CrossRef] [PubMed]

382. Melnik, B.C. Milk exosomal miRNAs: Potential drivers of AMPK-to-mTORC1 switching in $\beta$-cell de-differentiation of type 2 diabetes mellitus. Nutr. Metab. 2019, 16, 85. [CrossRef] [PubMed]

383. Ardestani, A.; Lupse, B.; Kido, Y.; Leibowitz, G.; Maedler, K. mTORC1 signaling: A double-edged sword in diabetic $\beta$ cells. Cell. Metab. 2018, 27, 314-331. [CrossRef] [PubMed]

384. Ma, F.; Wei, Z.; Shi, C.; Gan, Y.; Lu, J.; Frank, S.J.; Balducci, J.; Huang, Y. Signaling cross talk between growth hormone (GH) and insulin-like growth factor-I (IGF-I) in pancreatic islet $\beta$-cells. Mol. Endocrinol. 2011, 25, 2119-2133. [CrossRef]

385. Huang, Y.; Chang, Y. Regulation of pancreatic islet beta-cell mass by growth factor and hormone signaling. Prog. Mol. Biol. Transl. Sci. 2014, 121, 321-349.

386. Wang, Y.; Sun, J.; Ni, Q.; Nie, A.; Gu, Y.; Wang, S.; Zhang, W.; Ning, G.; Wang, W.; Wang, Q. Dual effect of raptor on neonatal $\beta$-cell proliferation and identity maintenance. Diabetes 2019, 68, 1950-1964. [CrossRef]

387. Jaafar, R.; Tran, S.; Shah, A.N.; Sun, G.; Valdearcos, M.; Marchetti, P.; Masini, M.; Swisa, A.; Giacometti, S.; Bernal-Mizrachi, E.; et al. mTORC1 to AMPK switching underlies $\beta$-cell metabolic plasticity during maturation and diabetes. J. Clin. Invest. 2019, 129, 4124-4137. [CrossRef]

388. Gao, W.; Ge, S.; Sun, J. Ailanthone exerts anticancer effect by up-regulating miR-148a expression in MDA-MB-231 breast cancer cells and inhibiting proliferation, migration and invasion. Biomed. Pharmacother. 2019, 109, 1062-1069. [CrossRef]

389. Chakravarthy, H.; Gu, X.; Enge, M.; Dai, X.; Wang, Y.; Damond, N.; Downie, C.; Liu, K.; Wang, J.; Xing, Y.; et al. Converting adult pancreatic islet $\alpha$ cells into $\beta$ cells by targeting both Dnmt1 and Arx. Cell. Metab. 2017, 25, 622-634. [CrossRef]

390. De Candia, P.; Spinetti, G.; Specchia, C.; Sangalli, E.; La Sala, L.; Uccellatore, A.; Lupini, S.; Genovese, S.; Matarese, G.; Ceriello, A. A unique plasma microRNA profile defines type 2 diabetes progression. PLoS ONE 2017, 12, e0188980. [CrossRef]

391. Mirza, A.H.; Kaur, S.; Nielsen, L.B.; Størling, J.; Yarani, R.; Roursgaard, M.; Mathiesen, E.R.; Damm, P.; Svare, J.; Mortensen, H.B.; et al. Breast milk-derived extracellular vesicles enriched in exosomes from mothers with type 1 diabetes contain aberrant levels of microRNAs. Front. Immunol. 2019, 10, 2543. [CrossRef]

392. Xue, L.J.; Huang, Q.; Zeng, J.E.; Zhu, H.; Xu, C.Y. Up-regulation of receptor interaction protein 140 promotes glucolipotoxicityinduced damage in MIN6 cells. Cell. Mol. Biol. 2018, 64, 39-45. [CrossRef] 
393. Yan, J.; Liu, L.; Zhu, Y.; Huang, G.; Wang, P.P. The association between breastfeeding and childhood obesity: A meta-analysis. BMC Public Health 2014, 14, 1267. [CrossRef]

394. Iguacel, I.; Monje, L.; Cabero, M.J.; Moreno Aznar, L.A.; Samper, M.P.; Rodríguez-Palmero, M.; Rivero, M.; Rodríguez, G. Feeding patterns and growth trajectories in breast-fed and formula-fed infants during the introduction of complementary food. Nutr. Hosp. 2019, 36, 777-785. [CrossRef]

395. Rito, A.I.; Buoncristiano, M.; Spinelli, A.; Salanave, B.; Kunešová, M.; Hejgaard, T.; García Solano, M.; Fijałkowska, A.; Sturua, L.; Hyska, J.; et al. Association between characteristics at birth, breastfeeding and obesity in 22 countries: The WHO European Childhood Obesity Surveillance Initiative-COSI 2015/2017. Obes. Facts 2019, 12, 226-243. [CrossRef]

396. Qiao, J.; Dai, L.J.; Zhang, Q.; Ouyang, Y.Q. A meta-analysis of the association between breastfeeding and early childhood obesity. J. Pediatr. Nurs. 2020, 53, 57-66. [CrossRef]

397. Pope, M.; Budge, H.; Symonds, M.E. The developmental transition of ovine adipose tissue through early life. Acta Physiol. 2014, 210, 20-30. [CrossRef]

398. Villatoro, A.J.; Martín-Astorga, M.D.C.; Alcoholado, C.; Becerra, J. Canine colostrum exosomes: Characterization and influence on the canine mesenchymal stem cell secretory profile and fibroblast anti-oxidative capacity. BMC Vet. Res. 2020, 16, 417. [CrossRef]

399. Shah, K.B.; Chernausek, S.D.; Garman, L.D.; Pezant, N.P.; Plows, J.F.; Kharoud, H.K.; Demerath, E.W.; Fields, D.A. Human Milk Exosomal MicroRNA: Associations with maternal overweight/obesity and infant body composition at 1 month of life. Nutrients 2021, 13, 1091. [CrossRef]

400. Shabalina, I.G.; Petrovic, N.; de Jong, J.M.; Kalinovich, A.V.; Cannon, B.; Nedergaard, J. UCP1 in brite/beige adipose tissue mitochondria is functionally thermogenic. Cell. Rep. 2013, 5, 1196-1203. [CrossRef]

401. Bartesaghi, S.; Hallen, S.; Huang, L.; Svensson, P.A.; Momo, R.A.; Wallin, S.; Carlsson, E.K.; Forslöw, A.; Seale, P.; Peng, X.R. Thermogenic activity of UCP1 in human white fat-derived beige adipocytes. Mol. Endocrinol. 2015, 29, 130-139. [CrossRef]

402. Shore, A.; Karamitri, A.; Kemp, P.; Speakman, J.R.; Lomax, M.A. Role of Ucp1 enhancer methylation and chromatin remodelling in the control of Ucp1 expression in murine adipose tissue. Diabetologia 2010, 53, 1164-1173. [CrossRef]

403. Hayashi, K.; Funaba, M.; Murakami, M. Tissue-dependent DNA methylation of carp uncoupling protein 1 promoter. Physiol. Genomics 2019, 51, 623-629. [CrossRef]

404. Kiskinis, E.; Hallberg, M.; Christian, M.; Olofsson, M.; Dilworth, S.M.; White, R.; Parker, M.G. RIP140 directs histone and DNA methylation to silence Ucp1 expression in white adipocytes. EMBO J. 2007, 26, 4831-4840. [CrossRef]

405. Xi, Y.; Jiang, X.; Li, R.; Chen, M.; Song, W.; Li, X. The levels of human milk microRNAs and their association with maternal weight characteristics. Eur. J. Clin. Nutr. 2016, 70, 445-449. [CrossRef]

406. Hallberg, M.; Morganstein, D.L.; Kiskinis, E.; Shah, K.; Kralli, A.; Dilworth, S.M.; White, R.; Parker, M.G.; Christian, M. A functional interaction between RIP140 and PGC-1alpha regulates the expression of the lipid droplet protein CIDEA. Mol. Cell. Biol. 2008, 28, 6785-6795. [CrossRef]

407. Scarpulla, R.C.; Vega, R.B.; Kelly, D.P. Transcriptional integration of mitochondrial biogenesis. Trends Endocrinol. Metab. 2012, 23, 459-466. [CrossRef]

408. Villena, J.A. New insights into PGC-1 coactivators: Redefining their role in the regulation of mitochondrial function and beyond. FEBS J. 2015, 282, 647-672. [CrossRef]

409. Leonardsson, G.; Steel, J.H.; Christian, M.; Pocock, V.; Milligan, S.; Bell, J.; So, P.W.; Medina-Gomez, G.; Vidal-Puig, A.; White, R.; et al. Nuclear receptor corepressor RIP140 regulates fat accumulation. Proc. Natl. Acad. Sci. USA 2004, 101, 8437-8442. [CrossRef]

410. White, R.; Morganstein, D.; Christian, M.; Seth, A.; Herzog, B.; Parker, M.G. Role of RIP140 in metabolic tissues: Connections to disease. FEBS Lett. 2008, 582, 39-45. [CrossRef]

411. Fritah, A.; Christian, M.; Parker, M.G. The metabolic coregulator RIP140: An update. Am. J. Physiol. Endocrinol. Metab. 2010, 299, E335-E340. [CrossRef] [PubMed]

412. Mota de Sá, P.; Richard, A.J.; Hang, H.; Stephens, J.M. Transcriptional regulation of adipogenesis. Compr. Physiol. 2017, 7, 635-674. [PubMed]

413. Chen, Y.; Siegel, F.; Kipschull, S.; Haas, B.; Fröhlich, H.; Meister, G.; Pfeifer, A. miR-155 regulates differentiation of brown and beige adipocytes via a bistable circuit. Nat. Commun. 2013, 4, 1769. [CrossRef] [PubMed]

414. Gharanei, S.; Shabir, K.; Brown, J.E.; Weickert, M.O.; Barber, T.M.; Kyrou, I.; Randeva, H.S. Regulatory microRNAs in brown, brite and white adipose tissue. Cells 2020, 9, 2489. [CrossRef]

415. Shi, C.; Zhang, M.; Tong, M.; Yang, L.; Pang, L.; Chen, L.; Xu, G.; Chi, X.; Hong, Q.; Ni, Y.; et al. miR-148a is associated with obesity and modulates adipocyte differentiation of mesenchymal stem cells through Wnt signaling. Sci. Rep. 2015, 5, 9930. [CrossRef]

416. Shi, C.; Huang, F.; Gu, X.; Zhang, M.; Wen, J.; Wang, X.; You, L.; Cui, X.; Ji, C.; Guo, X. Adipogenic miRNA and meta-signature miRNAs involved in human adipocyte differentiation and obesity. Oncotarget 2016, 7, 40830-40845. [CrossRef]

417. Cho, Y.M.; Kim, T.M.; Hun Kim, D.; Hee Kim, D.; Jeong, S.W.; Kwon, O.J. miR-148a is a downstream effector of X-box-binding protein 1 that silences Wnt10b during adipogenesis of 3T3-L1 cells. Exp. Mol. Med. 2016, 48, e226. [CrossRef]

418. Tian, L.; Zheng, F.; Li, Z.; Wang, H.; Yuan, H.; Zhang, X.; Ma, Z.; Li, X.; Gao, X.; Wang, B. miR-148a-3p regulates adipocyte and osteoblast differentiation by targeting lysine-specific demethylase 6b. Gene 2017, 627, 32-39. [CrossRef]

419. He, H.; Cai, M.; Zhu, J.; Xiao, W.; Liu, B.; Shi, Y.; Yang, X.; Liang, X.; Zheng, T.; Hu, S.; et al. miR-148a-3p promotes rabbit preadipocyte differentiation by targeting PTEN. In Vitro Cell. Dev. Biol. Anim. 2018, 54, 241-249. [CrossRef] 
420. Jin, X.; Hao, Z.; Zhao, M.; Shen, J.; Ke, N.; Song, Y.; Qiao, L.; Lu, Y.; Hu, L.; Wu, X.; et al. MicroRNA-148a regulates the proliferation and differentiation of ovine preadipocytes by targeting PTEN. Animals 2021, 11, 820. [CrossRef]

421. Yi, T.; Choi, H.M.; Park, R.W.; Sohn, K.Y.; Kim, I.S. Transcriptional repression of type I procollagen genes during adipocyte differentiation. Exp. Mol. Med. 2001, 33, 269-275. [CrossRef]

422. Liu, X.; Long, X.; Gao, Y.; Liu, W.; Hayashi, T.; Mizuno, K.; Hattori, S.; Fujisaki, H.; Ogura, T.; Onodera, S.; et al. Type I collagen inhibits adipogenic differentiation via YAP activation in vitro. J. Cell. Physiol. 2020, 235, 1821-1837. [CrossRef]

423. Xiong, J.; Ni, J.; Chen, C.; Wang, K. miR 148a 3p regulates alcoholic liver fibrosis through targeting ERBB3. Int. J. Mol. Med. 2020, 46, 1003-1012. [CrossRef]

424. Song, W.; Zhong, C.; Yuan, Y.; Zhu, Q.; Wang, Y.; Yin, H.; Li, D.; Zhang, Z.; Shu, G.; Yang, C.; et al. Peroxisome proliferatoractivated receptor-coactivator 1-beta (PGC-1 $\beta$ ) modulates the expression of genes involved in adipogenesis during preadipocyte differentiation in chicken. Gene 2020, 741, 144516. [CrossRef]

425. Kamei, Y.; Ohizumi, H.; Fujitani, Y.; Nemoto, T.; Tanaka, T.; Takahashi, N.; Kawada, T.; Miyoshi, M.; Ezaki, O.; Kakizuka, A PPARgamma coactivator 1beta/ERR ligand 1 is an ERR protein ligand, whose expression induces a high-energy expenditure and antagonizes obesity. Proc. Natl. Acad. Sci. USA 2003, 100, 12378-12383. [CrossRef]

426. Ji, H.; Lu, R.H.; Chang, Z.G.; Su, S.S.; Yang, G.S. PGC-1 $\beta$ modulates the expression of genes involved in mitochondrial function and adipogenesis during preadipocyte differentiation. Reprod. Domest. Anim. 2012, 47, 419-427. [CrossRef]

427. Scarpulla, R.C. Metabolic control of mitochondrial biogenesis through the PGC-1 family regulatory network. Biochim. Biophys. Acta 2011, 1813, 1269-1278. [CrossRef]

428. Fuller-Jackson, J.P.; Henry, B.A. Adipose and skeletal muscle thermogenesis: Studies from large animals. J. Endocrinol. 2018, 237, R99-R115. [CrossRef]

429. Hilse, K.E.; Kalinovich, A.V.; Rupprecht, A.; Smorodchenko, A.; Zeitz, U.; Staniek, K.; Erben, R.G.; Pohl, E.E. The expression of UCP3 directly correlates to UCP1 abundance in brown adipose tissue. Biochim. Biophys. Acta 2016, 1857, 72-78. [CrossRef]

430. Pohl, E.E.; Rupprecht, A.; Macher, G.; Hilse, K.E. Important trends in UCP3 investigation. Front. Physiol. 2019, 10, 470. [CrossRef]

431. Zanchi, D.; Depoorter, A.; Egloff, L.; Haller, S.; Mählmann, L.; Lang, U.E.; Drewe, J.; Beglinger, C.; Schmidt, A.; Borgwardt, S. The impact of gut hormones on the neural circuit of appetite and satiety: A systematic review. Neurosci. Biobehav. Rev. 2017, 80, 457-475. [CrossRef]

432. Clerc, P.; Coll Constans, M.G.; Lulka, H.; Broussaud, S.; Guigné, C.; Leung-Theung-Long, S.; Perrin, C.; Knauf, C.; Carpéné, C.; Pénicaud, L.; et al. Involvement of cholecystokinin 2 receptor in food intake regulation: Hyperphagia and increased fat deposition in cholecystokinin 2 receptor-deficient mice. Endocrinology 2007, 148, 1039-1049. [CrossRef]

433. Chen, H.; Kent, S.; Morris, M.J. Is the CCK2 receptor essential for normal regulation of body weight and adiposity? Eur. J. Neurosci. 2006, 24, 1427-1433. [CrossRef]

434. Yu, B.; Lv, X.; Su, L.; Li, J.; Yu, Y.; Gu, Q.; Yan, M.; Zhu, Z.; Liu, B. MiR-148a functions as a tumor suppressor by targeting CCK-BR via inactivating STAT3 and Akt in human gastric cancer. PLoS ONE 2016, 11, e0158961. [CrossRef] [PubMed]

435. Goedeke, L.; Rotllan, N.; Canfrán-Duque, A.; Aranda, J.F.; Ramírez, C.M.; Araldi, E.; Lin, C.S.; Anderson, N.N.; Wagschal, A.; de Cabo, R.; et al. MicroRNA-148a regulates LDL receptor and ABCA1 expression to control circulating lipoprotein levels. Nat. Med. 2015, 21, 1280-1289. [CrossRef] [PubMed]

436. Schmitz, G.; Buechler, C. ABCA1: Regulation, trafficking and association with heteromeric proteins. Ann. Med. 2002, 34, 334-347. [CrossRef] [PubMed]

437. Schmitz, G.; Langmann, T. Transcriptional regulatory networks in lipid metabolism control ABCA1 expression. Biochim. Biophys. Acta 2005, 1735, 1-19. [CrossRef] [PubMed]

438. He, Y.; Zhang, L.; Li, Z.; Gao, H.; Yue, Z.; Liu, Z.; Liu, X.; Feng, X.; Liu, P. RIP140 triggers foam-cell formation by repressing ABCA1/G1 expression and cholesterol efflux via liver $X$ receptor. FEBS Lett. 2015, 589, 455-460. [CrossRef] [PubMed]

439. Uccelli, A.; Moretta, L.; Pistoia, V. Mesenchymal stem cells in health and disease. Nat. Rev. Immunol. 2008, 8, 726-736. [CrossRef]

440. El-Farrash, R.A.; Ali, R.H.; Barakat, N.M. Post-natal bone physiology. Semin. Fetal Neonatal. Med. 2020, 25, 101077. [CrossRef]

441. Katsimbri, P. The biology of normal bone remodelling. Eur. J. Cancer Care 2017, 26, 6. [CrossRef]

442. Yang, Y.; Wu, F.; Dwyer, T.; Antony, B.; Winzenberg, T.; Jones, G. Associations of breastfeeding, maternal smoking, and birth weight with bone density and microarchitecture in young adulthood: A 25-year birth-cohort study. J. Bone Miner. Res. 2020, 35, 1652-1659. [CrossRef]

443. Behera, J.; Tyagi, N. Exosomes: Mediators of bone diseases, protection, and therapeutics potential. Oncoscience 2018, 5, 181-195. [CrossRef]

444. Qin, Y.; Sun, R.; Wu, C.; Wang, L.; Zhang, C. Exosome: A novel approach to stimulate bone regeneration through regulation of osteogenesis and angiogenesis. Int. J. Mol. Sci. 2016, 17, 712. [CrossRef]

445. Liu, M.; Sun, Y.; Zhang, Q. Emerging role of extracellular vesicles in bone remodeling. J. Dent. Res. 2018, 97, 859-868. [CrossRef]

446. Pethő, A.; Chen, Y.; George, A. Exosomes in extracellular matrix bone biology. Curr. Osteoporos. Rep. 2018, 16, 58-64. [CrossRef]

447. Huang, X.; Xiong, X.; Liu, J.; Zhao, Z.; Cen, X. MicroRNAs-containing extracellular vesicles in bone remodeling: An emerging frontier. Life Sci. 2020, 254, 117809. [CrossRef]

448. Blank, V.; Andrews, N.C. The Maf transcription factors: Regulators of differentiation. Trends Biochem. Sci. 1997, $22,437-441$. [CrossRef] 
449. Nishikawa, K.; Nakashima, T.; Takeda, S.; Isogai, M.; Hamada, M.; Kimura, A.; Kodama, T.; Yamaguchi, A.; Owen, M.J.; Takahashi, S.; et al. Maf promotes osteoblast differentiation in mice by mediating the age-related switch in mesenchymal cell differentiation. J. Clin. Invest. 2010, 120, 3455-3465. [CrossRef]

450. Cheng, P.; Chen, C.; He, H.B.; Hu, R.; Zhou, H.D.; Xie, H.; Zhu, W.; Dai, R.C.; Wu, X.P.; Liao, E.Y.; et al. miR-148a regulates osteoclastogenesis by targeting V-maf musculoaponeurotic fibrosarcoma oncogene homolog B. J. Bone Miner. Res. 2013, 28, 1180-1190. [CrossRef]

451. Oliveira, M.C.; Di Ceglie, I.; Arntz, O.J.; van den Berg, W.B.; van den Hoogen, F.H.; Ferreira, A.V.; van Lent, P.L.; van de Loo, F.A. Milk-derived nanoparticle fraction promotes the formation of small osteoclasts but reduces bone resorption. J. Cell. Physiol. 2017, 232, 225-233. [CrossRef]

452. Kelch, S.; Balmayor, E.R.; Seeliger, C.; Vester, H.; Kirschke, J.S.; van Griensven, M. miRNAs in bone tissue correlate to bone mineral density and circulating miRNAs are gender independent in osteoporotic patients. Sci. Rep. 2017, 7, 15861. [CrossRef]

453. Oliveira, M.C.; Arntz, O.J.; Blaney Davidson, E.N.; van Lent, P.L.; Koenders, M.I.; van der Kraan, P.M.; van den Berg, W.B.; Ferreira, A.V.; van de Loo, F.A. Milk extracellular vesicles accelerate osteoblastogenesis but impair bone matrix formation. J. Nutr. Biochem. 2016, 30, 74-84. [CrossRef]

454. Oliveira, M.C.; Pieters, B.C.H.; Guimarães, P.B.; Duffles, L.F.; Heredia, J.E.; Silveira, A.L.M.; Oliveira, A.C.C.; Teixeira, M.M.; Ferreira, A.V.M.; Silva, T.A.; et al. Bovine milk extracellular vesicles are osteoprotective by increasing osteocyte numbers and targeting RANKL/OPG system in experimental models of bone loss. Front. Bioeng. Biotechnol. 2020, 8, 891. [CrossRef]

455. Yun, B.; Maburutse, B.E.; Kang, M.; Park, M.R.; Park, D.J.; Kim, Y.; Oh, S. Short communication: Dietary bovine milk-derived exosomes improve bone health in an osteoporosis-induced mouse model. J. Dairy Sci. 2020, 103, 7752-7760. [CrossRef]

456. Lee, B.; Iwaniec, U.T.; Turner, R.T.; Lin, Y.W.; Clarke, B.L.; Gingery, A.; Wei, L.N. RIP140 in monocytes/macrophages regulates osteoclast differentiation and bone homeostasis. JCI Insight 2017, 2, e90517. [CrossRef]

457. Klein-Nulend, J.; Bacabac, R.G.; Bakker, A.D. Mechanical loading and how it affects bone cells: The role of the osteocyte cytoskeleton in maintaining our skeleton. Eur. Cell Mater. 2012, 24, 278-291. [CrossRef]

458. Walker, E.C.; Truong, K.; McGregor, N.E.; Poulton, I.J.; Isojima, T.; Gooi, J.H.; Martin, T.J.; Sims, N.A. Cortical bone maturation in mice requires SOCS3 suppression of gp130/STAT3 signalling in osteocytes. eLife 2020, 9, e56666. [CrossRef]

459. Kylmaoja, E.; Nakamura, M.; Tuukkanen, J. Osteoclasts and remodeling based bone formation. Curr. Stem Cell Res. Ther. 2016, 11, 626-633. [CrossRef]

460. Zempleni, J.; US Department of Agriculture. Milk Findings May Help Infants Worldwide. Available online: https:/ /www.usda. gov/media/blog/2020/06/01/milk-findings-may-help-infants-worldwide (accessed on 10 May 2021).

461. Li, Y.; Nguyen, D.N.; de Waard, M.; Christensen, L.; Zhou, P.; Jiang, P.; Sun, J.; Bojesen, A.M.; Lauridsen, C.; Lykkesfeldt, J.; et al. Pasteurization procedures for donor human milk affect body growth, intestinal structure, and resistance against bacterial infections in preterm pigs. J. Nutr. 2017, 147, 1121-1130. [CrossRef]

462. Sun, H.; Cao, Y.; Han, S.; Cheng, R.; Liu, L.; Liu, J.; Xia, S.; Zhang, J.; Li, Z.; Cheng, X.; et al. A randomized controlled trial protocol comparing the feeds of fresh versus frozen mother's own milk for preterm infants in the NICU. Trials 2020, 21, 170. [CrossRef] [PubMed]

463. Oliveira, M.M.; Aragon, D.C.; Bomfim, V.S.; Trevilato, T.M.B.; Alves, L.G.; Heck, A.R.; Martinez, F.E.; Camelo, J.S., Jr. Development of a human milk concentrate with human milk lyophilizate for feeding very low birth weight preterm infants: A preclinical experimental study. PLoS ONE 2019, 14, e0210999. [CrossRef] [PubMed]

464. Hahn, W.H.; Kim, J.; Song, S.; Park, S.; Kang, N.M. The human milk oligosaccharides are not affected by pasteurization and freeze-drying. J. Matern. Fetal Neonatal Med. 2019, 32, 985-991. [CrossRef] [PubMed]

465. Hahn, W.H.; Bae, S.P.; Song, S.; Park, S.; Lee, J.; Seo, J.B.; Kang, N.M. The freeze-drying does not influence the proteomic profiles of human milk. J. Matern. Fetal Neonatal Med. 2020, 33, 2069-2074. [CrossRef]

466. Charoenviriyakul, C.; Takahashi, Y.; Nishikawa, M.; Takakura, Y. Preservation of exosomes at room temperature using lyophilization. Int. J. Pharm. 2018, 553, 1-7. [CrossRef]

467. Zhang, Y.; Bi, J.; Huang, J.; Tang, Y.; Du, S.; Li, P. Exosome: A review of its classification, isolation techniques, storage, diagnostic and targeted therapy applications. Int. J. Nanomed. 2020, 15, 6917-6934. [CrossRef]

468. Stephen, B.J.; Pareek, N.; Saeed, M.; Kausar, M.A.; Rahman, S.; Datta, M. Xeno-miRNA in maternal-infant immune crosstalk: An aid to disease alleviation. Front. Immunol. 2020, 11, 404. [CrossRef]

469. Marriott, M.; Schoenthal, L. An experimental study of the use of unsweetened evaporated milk for the preparation of infant feeding formulas. Arch. Pediatr. 1929, 46, 135-148.

470. Bryder, L. From breast to bottle: A history of modern infant feeding. Endeavour 2009, 33, 54-59. [CrossRef]

471. Koletzko, B.; von Kries, R.; Closa, R.; Escribano, J.; Scaglioni, S.; Giovannini, M.; Beyer, J.; Demmelmair, H.; Gruszfeld, D.; Dobrzanska, A.; et al. Lower protein in infant formula is associated with lower weight up to age $2 \mathrm{y}$ : A randomized clinical trial. Am. J. Clin. Nutr. 2009, 89, 1836-1845.

472. Weber, M.; Grote, V.; Closa-Monasterolo, R.; Escribano, J.; Langhendries, J.P.; Dain, E.; Giovannini, M.; Verduci, E.; Gruszfeld, D.; Socha, P.; et al. Lower protein content in infant formula reduces BMI and obesity risk at school age: Follow-up of a randomized trial. Am. J. Clin. Nutr. 2014, 99, 1041-1051. [CrossRef] 
473. Patro-Gołąb, B.; Zalewski, B.M.; Kołodziej, M.; Kouwenhoven, S.; Poston, L.; Godfrey, K.M.; Koletzko, B.; van Goudoever, J.B.; Szajewska, H. Nutritional interventions or exposures in infants and children aged up to 3 years and their effects on subsequent risk of overweight, obesity and body fat: A systematic review of systematic reviews. Obes. Rev. 2016, 17, 1245-1257. [CrossRef]

474. Melnik, B.C. Excessive leucine-mTORC1-signalling of cow milk-based infant formula: The missing link to understand early childhood obesity. J. Obes. 2012, 2012, 197653. [CrossRef]

475. Melnik, B.C. The potential mechanistic link between allergy and obesity development and infant formula feeding. Allergy Asthma Clin. Immunol. 2014, 10, 37. [CrossRef]

476. Capuco, A.V.; Akers, R.M. The origin and evolution of lactation. J. Biol. 2009, 8, 37. [CrossRef]

477. King, F.T. Feeding and Care of Baby; Macmillan: London, UK, 1913; pp. 3, 17, 43.

478. Leung, A.K.; Sauve, R.S. Breast is best for babies. J. Natl. Med. Assoc. 2005, 97, 1010-1019. 